
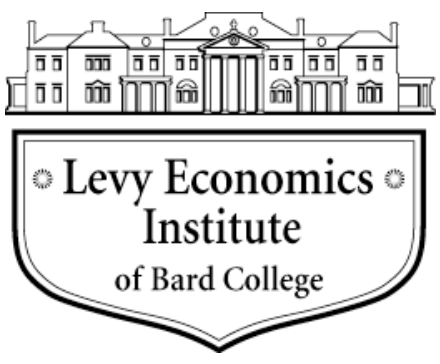

Working Paper No. 858

\title{
Gender Dimensions of Inequality in the Countries of Central Asia, South Caucasus, and Western CIS*
}

by

Tamar Khitarishvili

Levy Economics Institute of Bard College

January 2016

\footnotetext{
* Background paper prepared for the United Nations Development Program's 2016 Regional Human Development Report for Europe and Central Asia.
}

The Levy Economics Institute Working Paper Collection presents research in progress by Levy Institute scholars and conference participants. The purpose of the series is to disseminate ideas to and elicit comments from academics and professionals.

Levy Economics Institute of Bard College, founded in 1986, is a nonprofit, nonpartisan, independently funded research organization devoted to public service. Through scholarship and economic research it generates viable, effective public policy responses to important economic problems that profoundly affect the quality of life in the United States and abroad.

\author{
Levy Economics Institute \\ P.O. Box 5000 \\ Annandale-on-Hudson, NY 12504-5000 \\ http://www.levyinstitute.org
}

Copyright (C Levy Economics Institute 2016 All rights reserved

ISSN 1547-366X 


\section{ABSTRACT}

The collapse of the Soviet Union initiated an unprecedented social and economic transformation of the successor countries and altered the gender balance in a region that counted gender equality as one of the key legacies of its socialist past. The transition experience of the region has amply demonstrated that the changes in the gender balance triggered by economic shifts are far from obvious, and that economic expansion and women's economic empowerment do not always go hand in hand. Therefore, active measures to enhance women's economic empowerment should be of central concern to the policy dialogue aimed at poverty and inequality reduction and inclusive growth. In this paper, we establish the current state of various dimensions of gender inequalities and their past dynamics in the countries of Central Asia (Kazakhstan, Kyrgyzstan, Tajikistan, Turkmenistan, and Uzbekistan), South Caucasus (Armenia, Azerbaijan, and Georgia), and Western CIS (Belarus, Moldova, and Ukraine), and propose steps aimed at reducing those inequalities in the context of inclusive growth, decent job creation, and economic empowerment.

Keywords: Gender Economics, Inequality, Transition Countries, Human Development, Western CIS, Central Asia, South Caucasus

JEL Classifications: J16, P2 


\section{INTRODUCTION}

The collapse of the Soviet Union has initiated an unprecedented social and economic transformation of the successor countries and has altered the gender balance in a region that counted gender equality as one of the key legacies of its socialist past. The transition experience of the region has amply demonstrated that the changes in the gender balance triggered by economic shifts are far from obvious and that economic expansion and women's economic empowerment do not always go hand in hand (Sattar 2012; Elborgh-Woytek et al. 2013; Woetzel et al. 2015). Therefore, active measures to enhance women's economic empowerment should be of central concern to the policy dialogue aimed at inclusive growth and poverty and inequality reduction (Çagatay 1998). In this paper, we establish the current state of various dimensions of gender inequalities and their past dynamics in the countries of Central Asia (Kazakhstan, Kyrgyzstan, Tajikistan, Turkmenistan, and Uzbekistan), South Caucasus (Armenia, Azerbaijan, and Georgia), and Western CIS (Belarus, Moldova, and Ukraine) and propose steps aimed at reducing them in the context of inclusive growth, decent job creation, and economic empowerment.

The 11 countries of Central Asia, South Caucasus, and Western CIS represent a heterogeneous group that includes energy-exporting countries (Azerbaijan, Kazakhstan, and Turkmenistan), agriculture-dependent economies (Armenia, Georgia, Moldova, Ukraine, Kyrgyzstan, Tajikistan, and Uzbekistan), and relatively diversified economies with a stronger industrial sector (Belarus). Gender inequalities tend to be smaller in the countries of Western CIS compared to the countries of Central Asia and South Caucasus. However, not all countries fit this pattern perfectly. On some measures, Moldova resembles the countries of the South Caucasus, Kazakhstan stands out among Central Asian countries, and Azerbaijan looks more like a Central Asian country than a South Caucasian one. Despite these differences, gender inequities are pervasive in many aspects of economic, social, and political participation in the whole region. 


\section{LABOR FORCE PARTICIPATION, EMPLOYMENT, AND UNEMPLOYMENT}

One of the most important domains in which gender inequalities manifest themselves is labor markets. Despite the economic expansion during the last two decades, robust employment growth for either men or women has been elusive. Indeed, the transition process has been associated with stable or declining labor force participation rates for men and women due to the high migration flows and the discouraged worker effects. ${ }^{1}$ In the process, the gender gaps in participation rates either remained stable or widened in most of the countries. Azerbaijan and Kazakhstan are exceptions as female labor force participation rates in these countries have caught up with the male rates and are the highest among all the countries in the region (figure 1). In fact, in Azerbaijan, the female youth participation rate surpassed its male counterpart in 2008. If the expanding energy industry is in part responsible for this change, it does not appear to be the case in Turkmenistan, another energy-rich country, in which the female labor force participation rate is the second lowest and the gender gap in labor force participation rates is the highest.

Figure 1. Labor Force Participation Rates

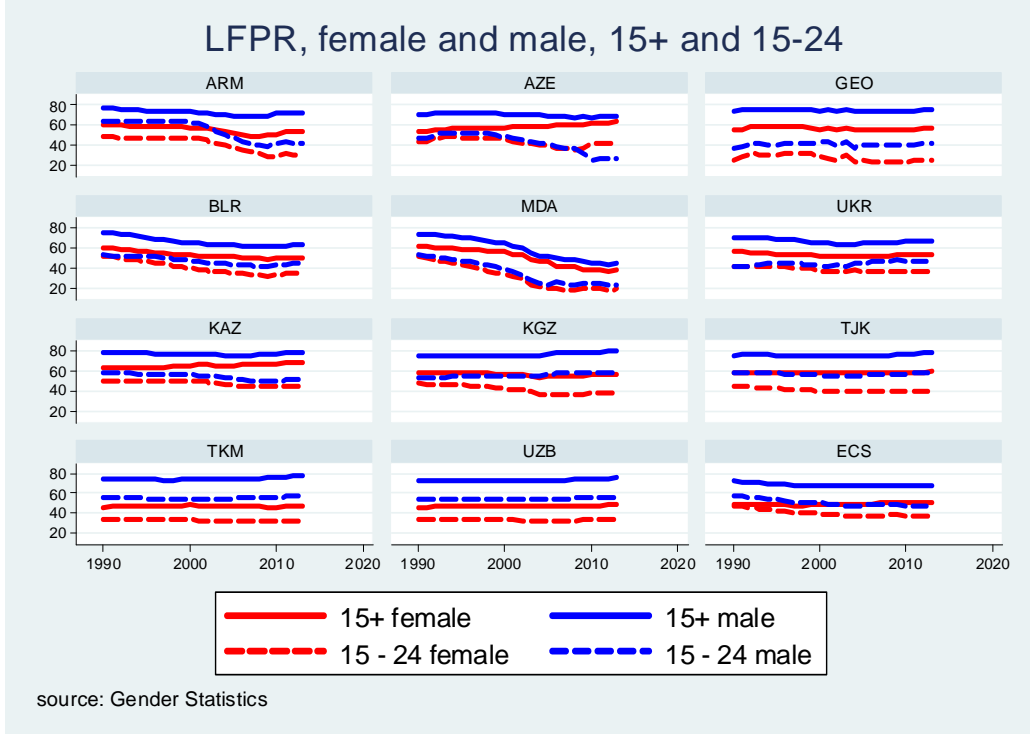

${ }^{1}$ The particularly sharp decline in Moldova was due to the categorization of emigrants as inactive population. 
Moldova is the most gender equal based on the labor force participation rates (figure 2); however this appears to be a reflection of the weak state of labor markets rather than an indication of a level playing field for both men and women, given that the labor force participation rates for both men and women are the lowest in the region.

Figure 2. Labor Force Participation Rates, 2000-2013

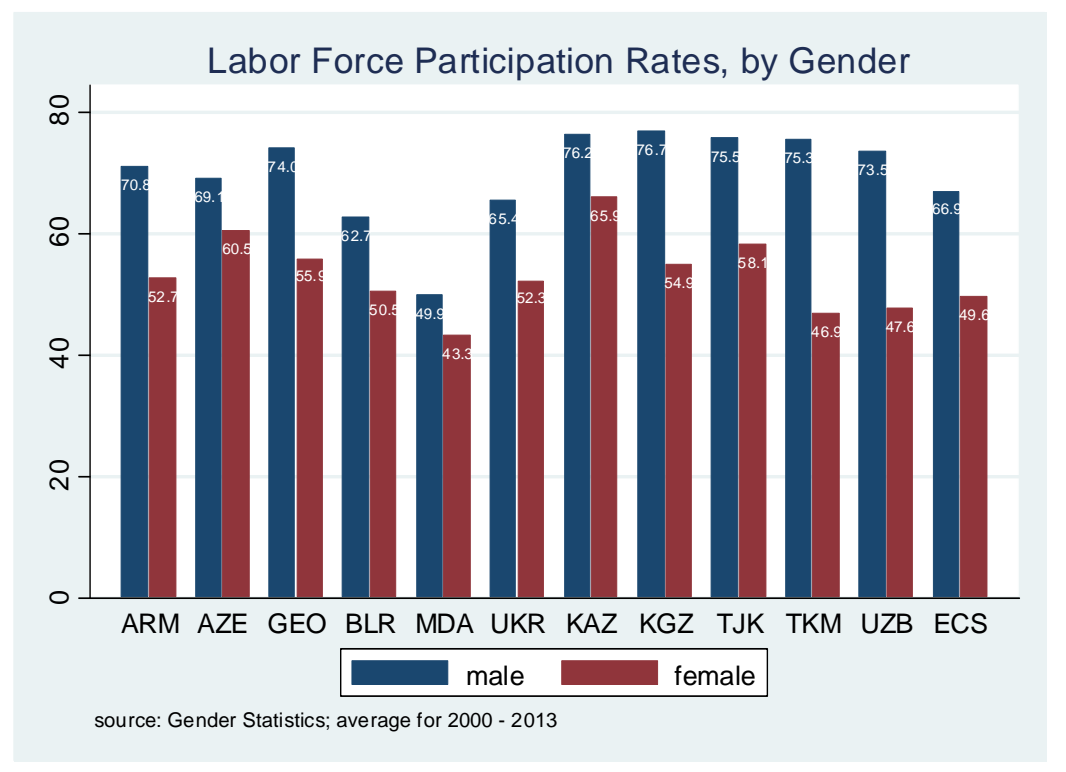

The stable and declining labor force participation rate patterns can be linked to migration and the discouraged worker effect. However, weak employment growth has also played a role (figures 3 and 4). This is the case in Moldova, which experienced considerable declines in the employment rate of both men and women. Similarly, the increase in the female labor force participation rates in Azerbaijan and Kazakhstan appears to stem from the notable increases in the employment rates for working-age women so much so that the female employment rates in these countries are the highest in the region and are well above the average for Europe and Central Asia.

The countries of the region have had varied success at tackling unemployment, especially Armenia and Georgia, in which the official unemployment rates remain well above 15 percent (figures 5 and 6). In Belarus, Moldova, and Ukraine, the unemployment rates tend to be lower than in Central Asia and South Caucasus and in these countries female unemployment rates are 
below their male counterparts. In contrast, in Central Asia and South Caucasus proportionately more women tend to be unemployed compared to men.

\section{Figure 3. Trends in Employment Rates}

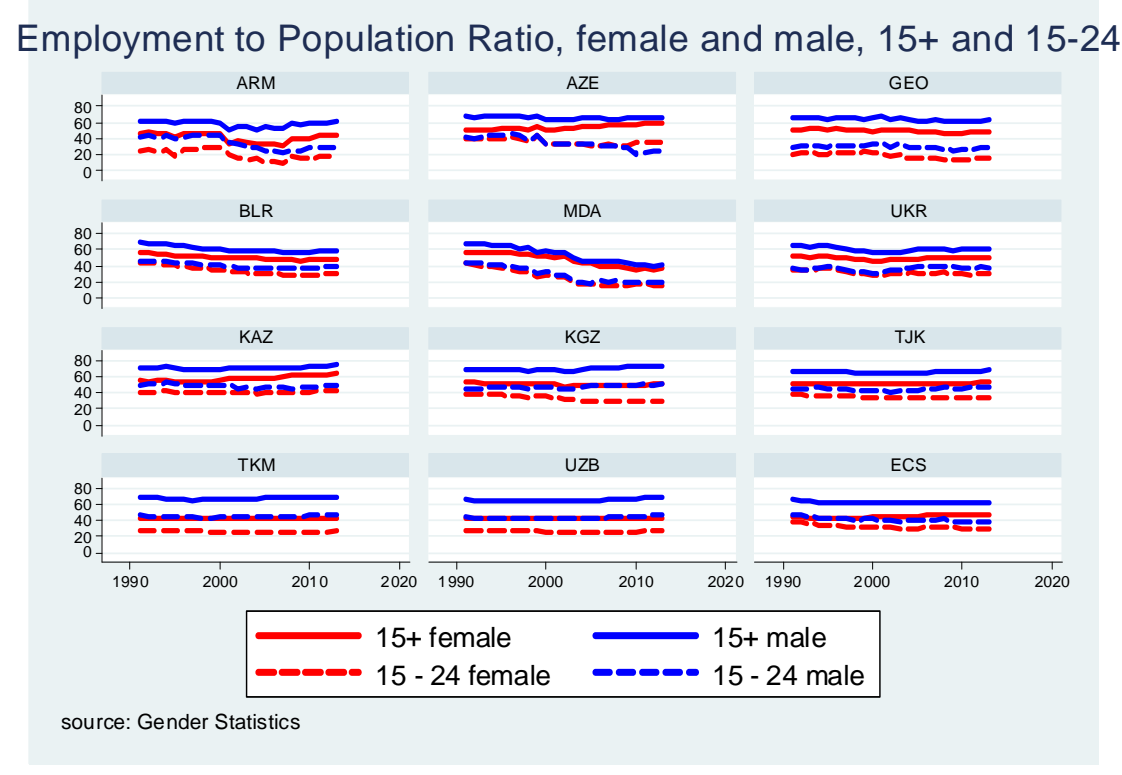

Figure 4. Employment Rates, 2000-2013

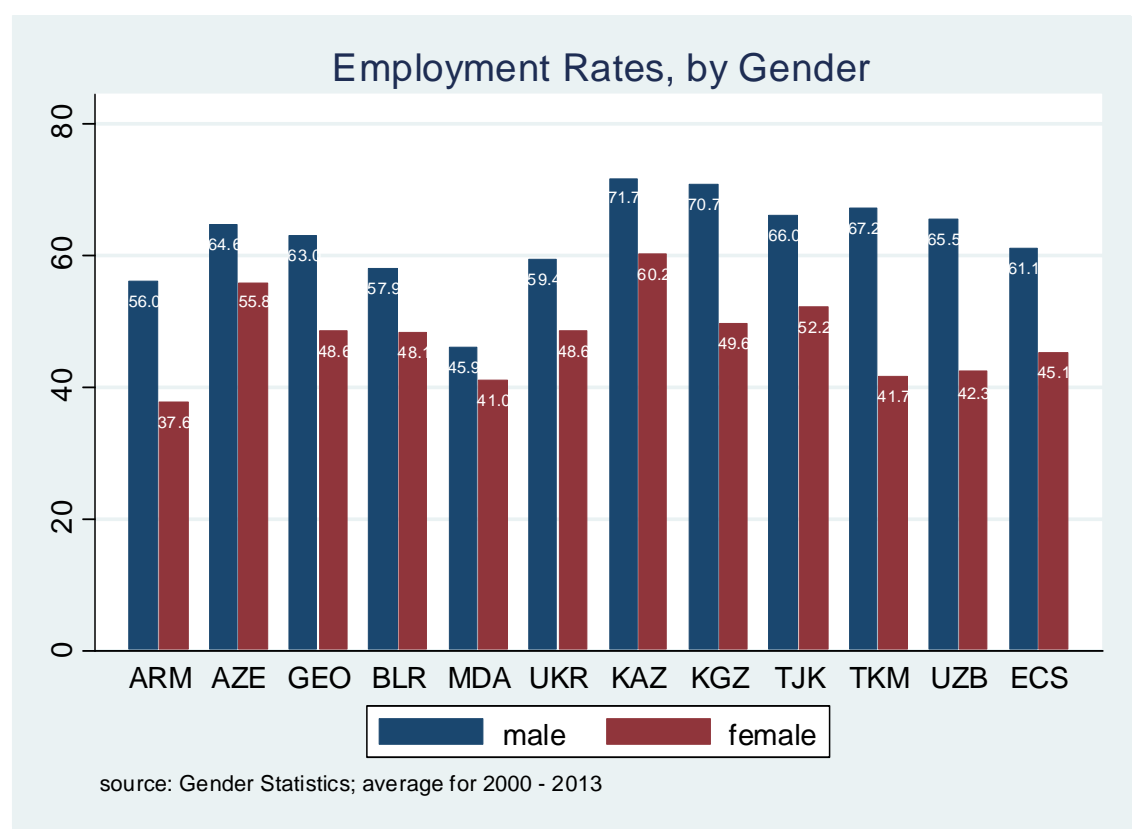


Figure 5. Trends in Unemployment Rates

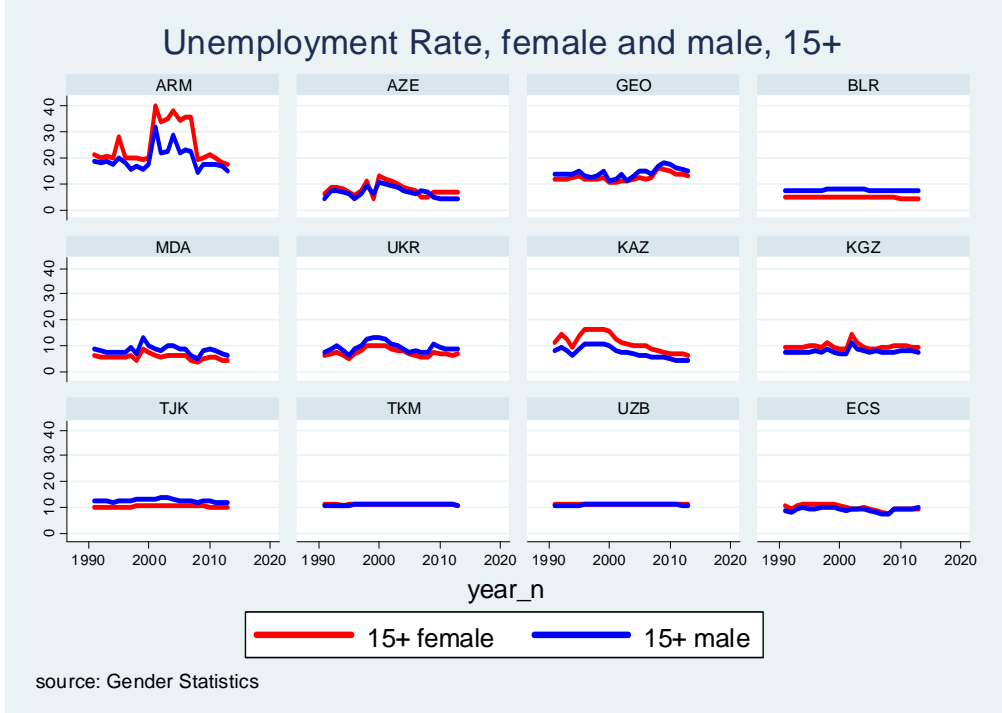

Figure 6. Unemployment Rates, 2000-2013

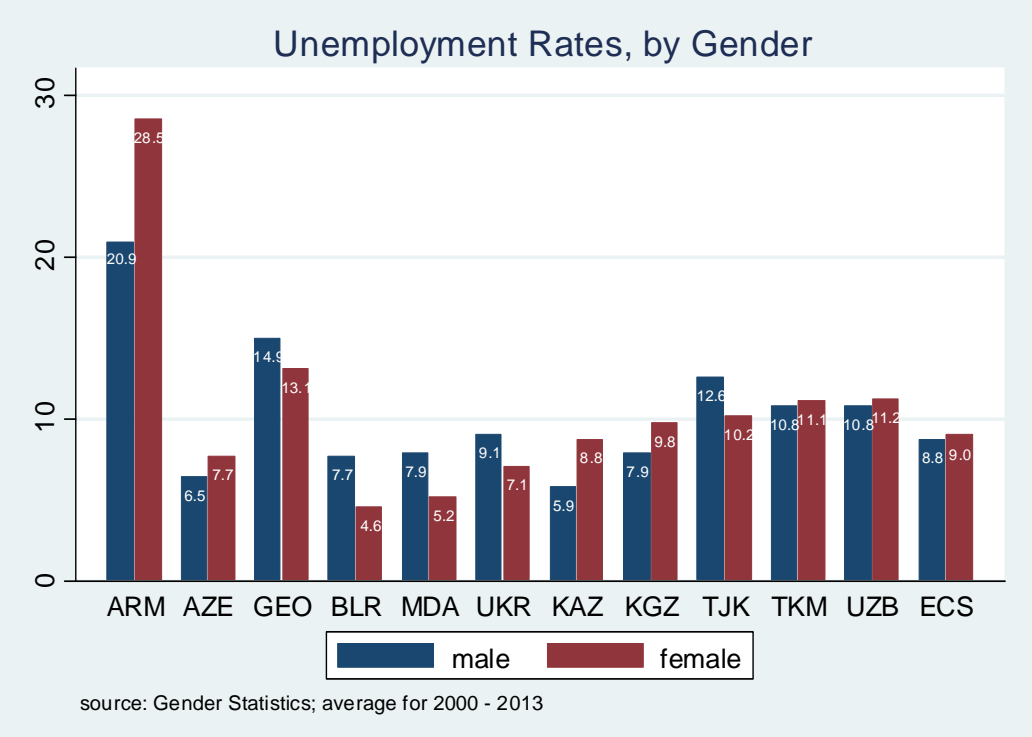

Shifts in these labor market indicators can in part be attributed to the changing output composition of their economies. Since the mid-1990s, all countries of the region experienced the contraction of the agricultural sector and the corresponding expansion of the service sector. Azerbaijan, Kazakhstan, and Turkmenistan are the exception in that they experienced the 
accompanying expansion of the industrial sector driven by the energy sector. As a result, in these countries the industrial sector comprises 40 percent or more of the GDP (figure 7).

\section{Figure 7. Output Composition}

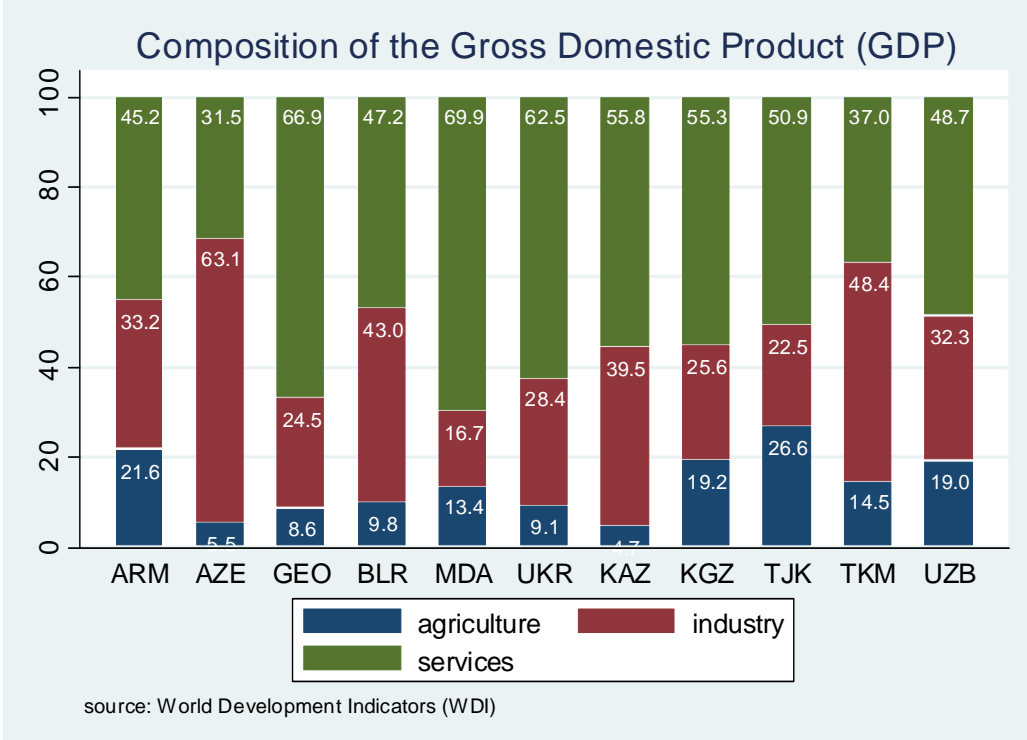

Despite these changes in the output structure, however, the sectoral composition of employment has not dramatically changed over the last two decades. ${ }^{2}$ The service sector employs the largest portion of the workforce, especially among women (figure 8). In turn, agriculture employs at least 30 percent of the female and male workforce in all countries but Belarus, despite its relatively low contribution to the output. This reveals the pervasiveness of low productivity agriculture throughout the region. ${ }^{3}$ In Azerbaijan and Kazakhstan, the industrial sector employs a small portion of workforce relative to its contribution to total output, likely due to the capital-intensive nature of the energy sector.

\footnotetext{
${ }^{2}$ For the time-series plots of industrial composition of employment, see the appendix.

${ }^{3}$ According to UNFPA (2014), in Ukraine 19.4 percent of female workforce and 19.6 percent of male workforce were employed in agriculture in 2011.
} 
Figure 8. Industrial Composition of Female and Male Employment
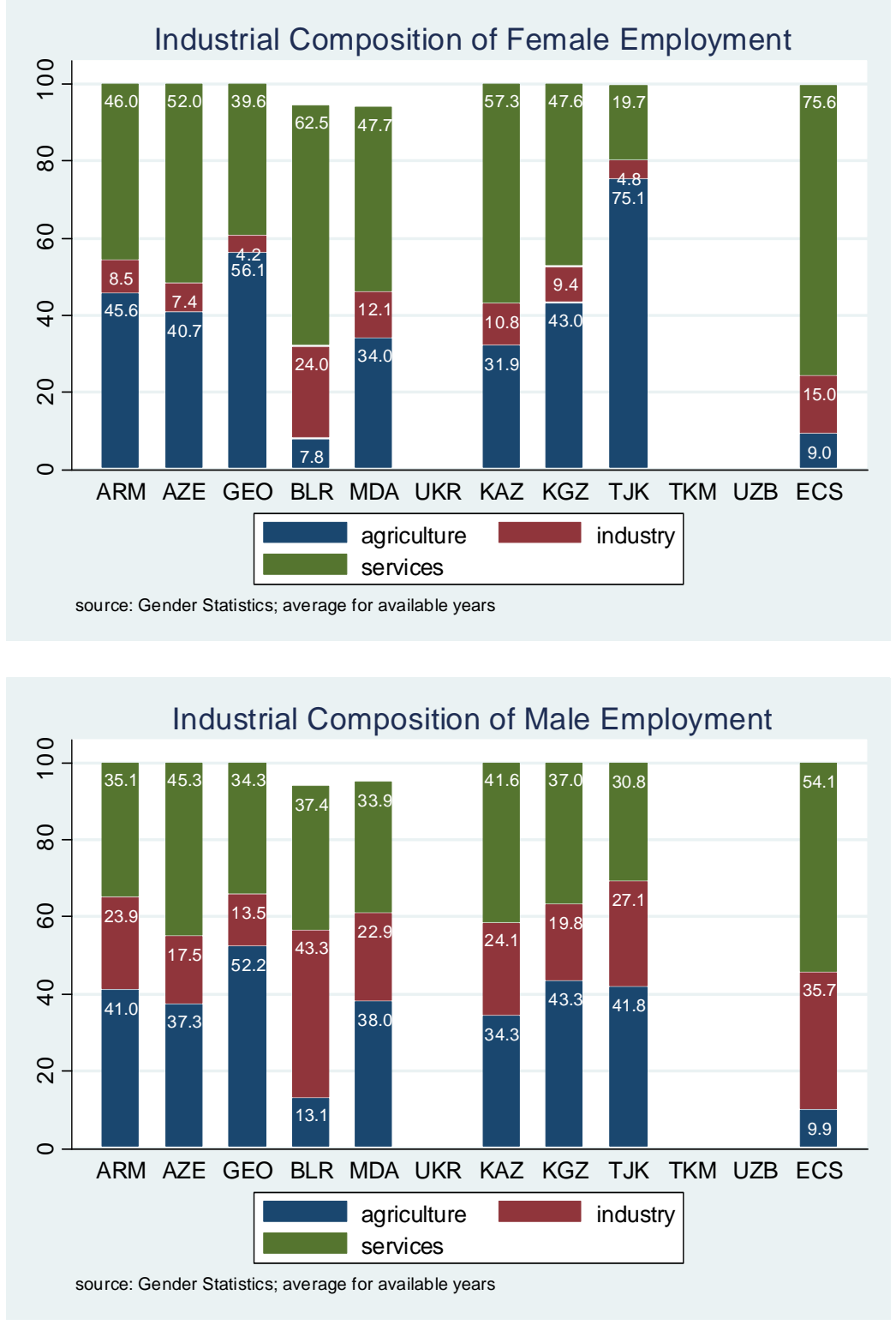

The analysis of the employment composition by type sheds additional light on the differences among the countries and, in particular, on the gender dimension of labor markets. In particular, wage employment comprises a larger portion of employment in Western CIS countries compared to the countries of the South Caucasus and Central Asia (figure 9). In the case of Belarus, more than 90 percent of employed men and women are wage workers. However, there is no clear pattern in terms of the gender gap in wage employment. Proportionately more men are 
workers in the South Caucasus, but also in Ukraine and Kazakhstan, whereas proportionately more women are wage workers in Belarus, Moldova, Kyrgyz Republic, and Tajikistan.

Figure 9. Proportion of Wage Employment in Total Employment, by Gender

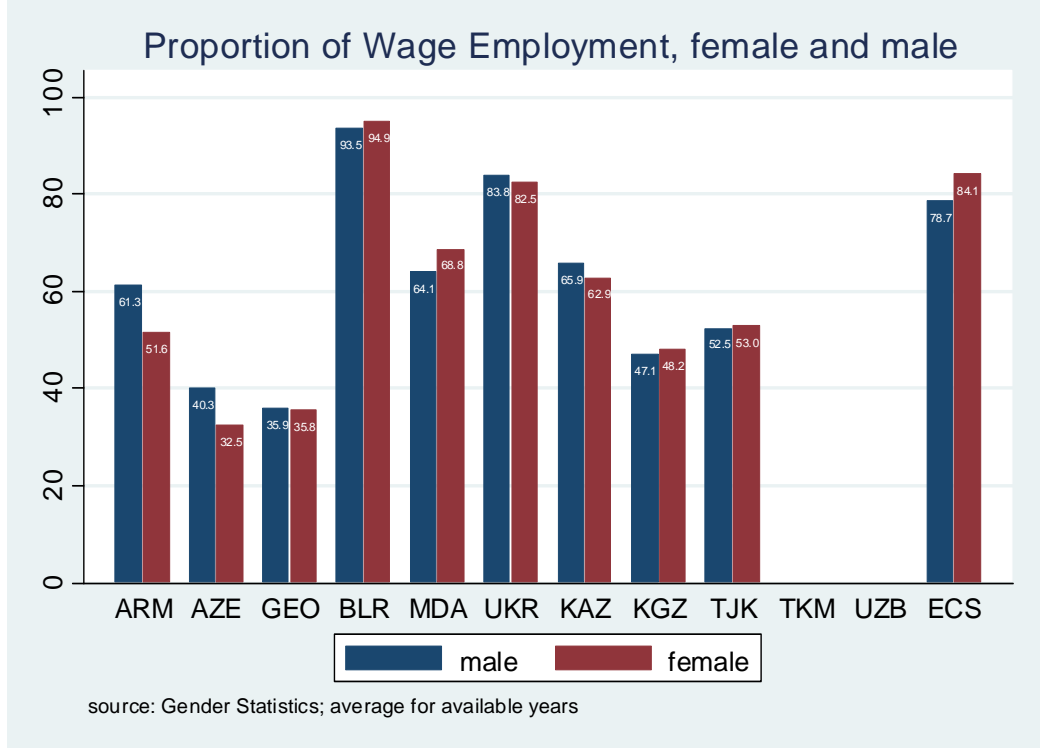

Among the self-employed, own-account workers (i.e., self-employed individuals without employees) represent the biggest category. Their proportion is sizable in all countries but Belarus, although no clear gender patterns emerge (figure 10). Contributing family workers are an especially large portion of employment in the countries of South Caucasus and Central Asia, except for Kazakhstan (figure 11). In their case proportionately more females are contributing family workers in these countries. Employers represent the smallest of all the employment types and proportionately more men are in this category (figure 12). 
Figure 10. Proportion of Own-Account Workers in Total Employment

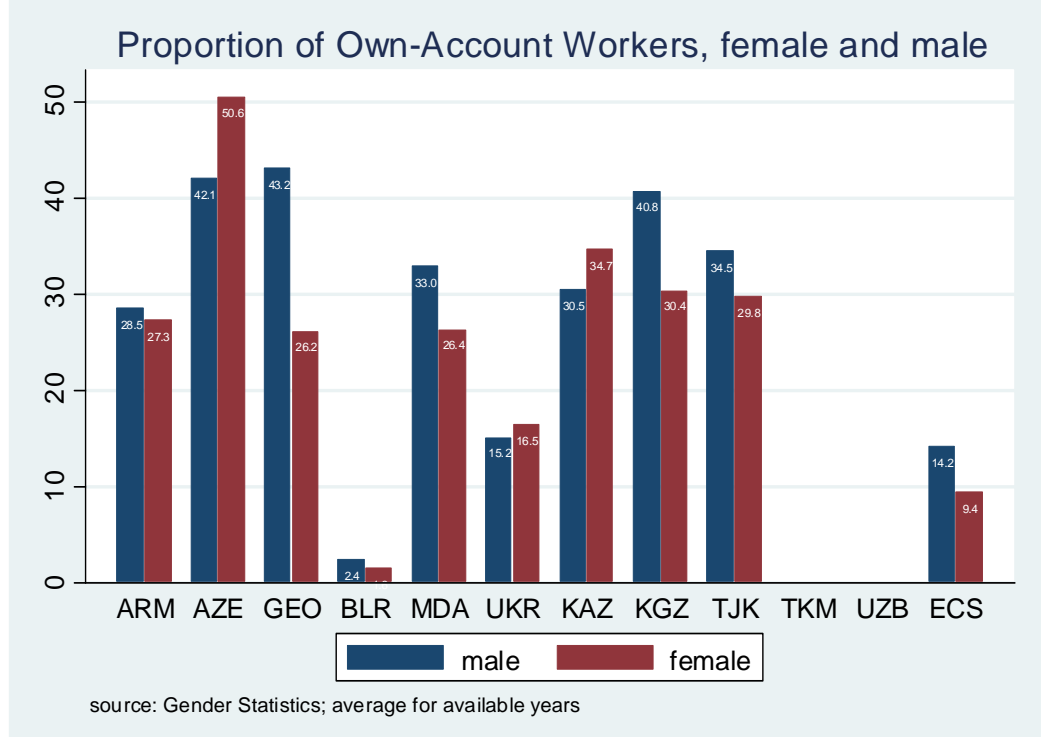

Figure 11. Proportion of Contributing Family Workers

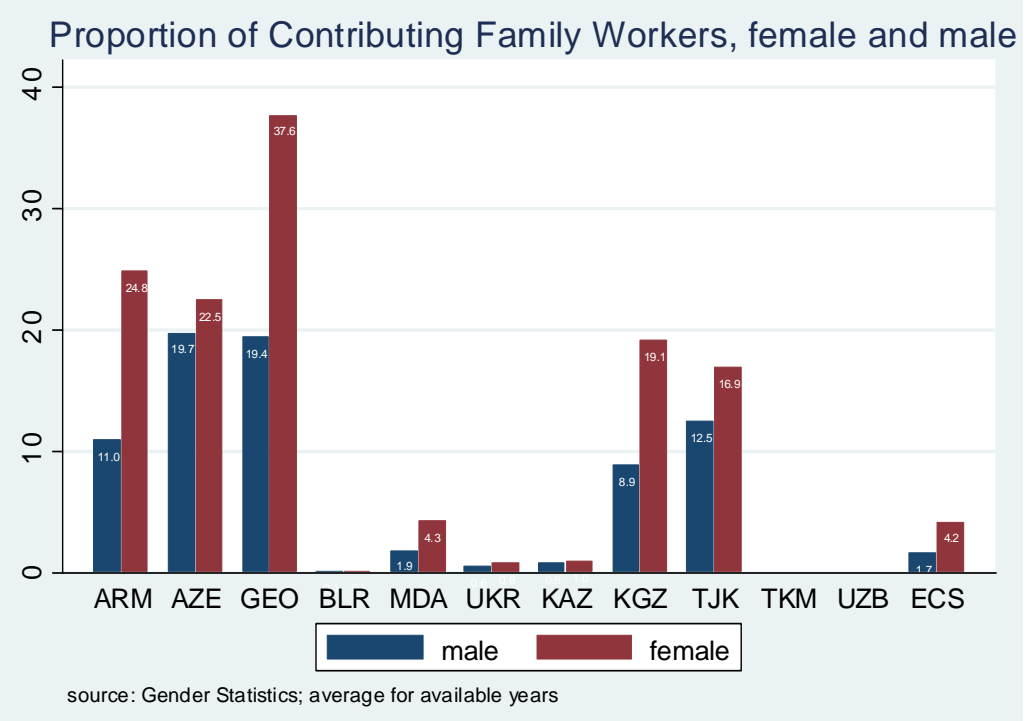




\section{Figure 12. Proportion of Employers}

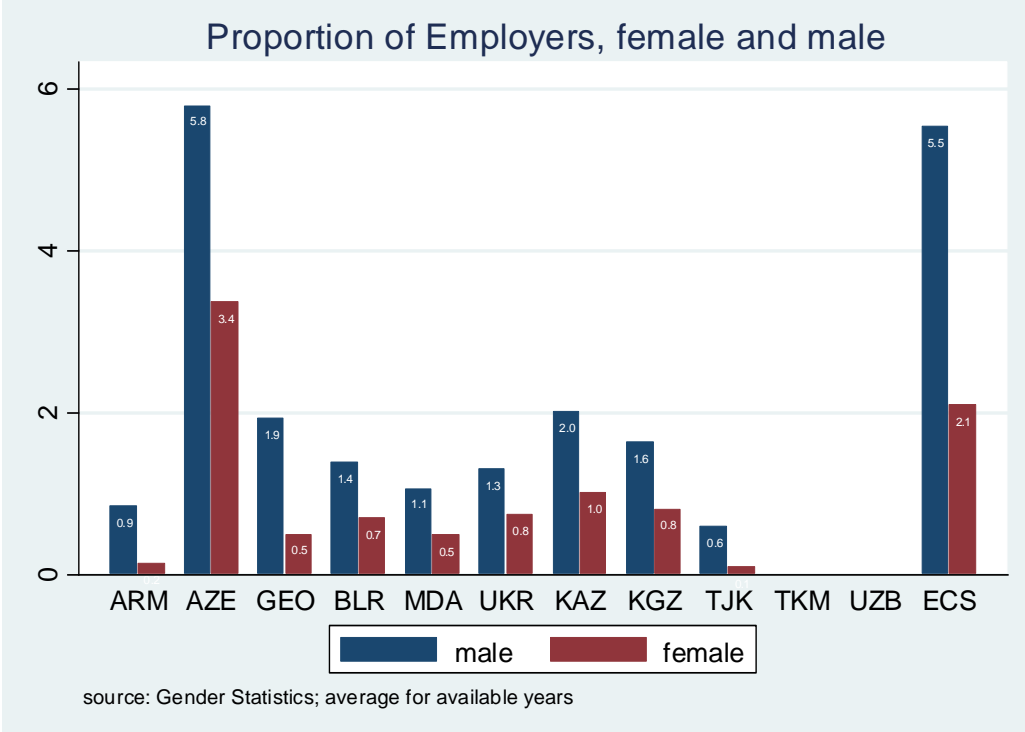

In sum, the analysis by employment type suggests that wage employment is very important in Belarus and Ukraine. Moldova is more similar to the South Caucasus countries in terms of the importance of self-employment, which seems to be connected to the relatively large size of the agricultural sector in these countries. Proportionately more women are contributing family workers in all countries of the region, but their proportions are especially high in South Caucasus and Central Asia.

\section{ENTREPRENEURSHIP AND PRIVATE SECTOR DEVELOPMENT}

These employment patterns can be partly explained by the private sector development in the region. Indeed, private sector growth has been viewed as holding a key to generating robust employment growth in transition countries (World Bank 2014). The experience of the countries in this region at expanding their private sector has varied. The current share of the private sector ranges from only 25 percent in Turkmenistan to 75 percent in Armenia, Azerbaijan, Georgia, and Kyrgyz Republic (figure 13). In the case of Belarus, the share of the private sector may be even smaller than the reported 30 percent because the private sector contribution includes the output of the private enterprises in which the state owns the majority of shares (Smallbone and Welter 
2010). The available data for the private sector shares in employment largely parallels the shares in GDP. Male shares in private employment are consistently higher than female shares due to the stronger representation of women in the public sector. ${ }^{4}$

Figure 13. Private Shares in GDP and Employment

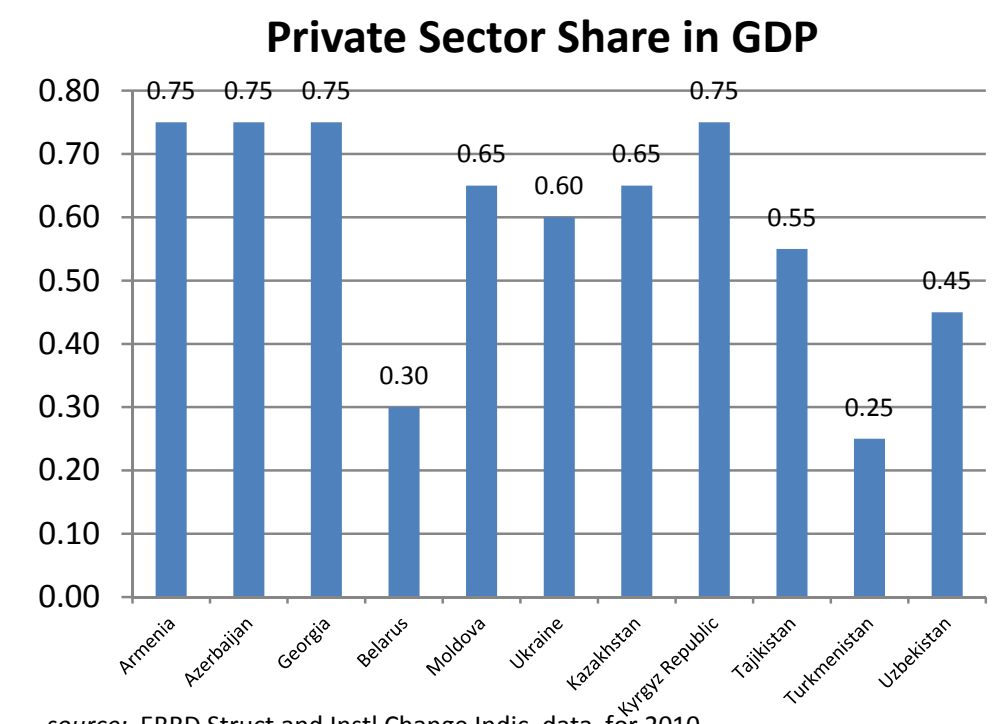

source: EBRD Struct and Instl Change Indic, data for 2010

\section{Share of Private Sector Employment, 2010}
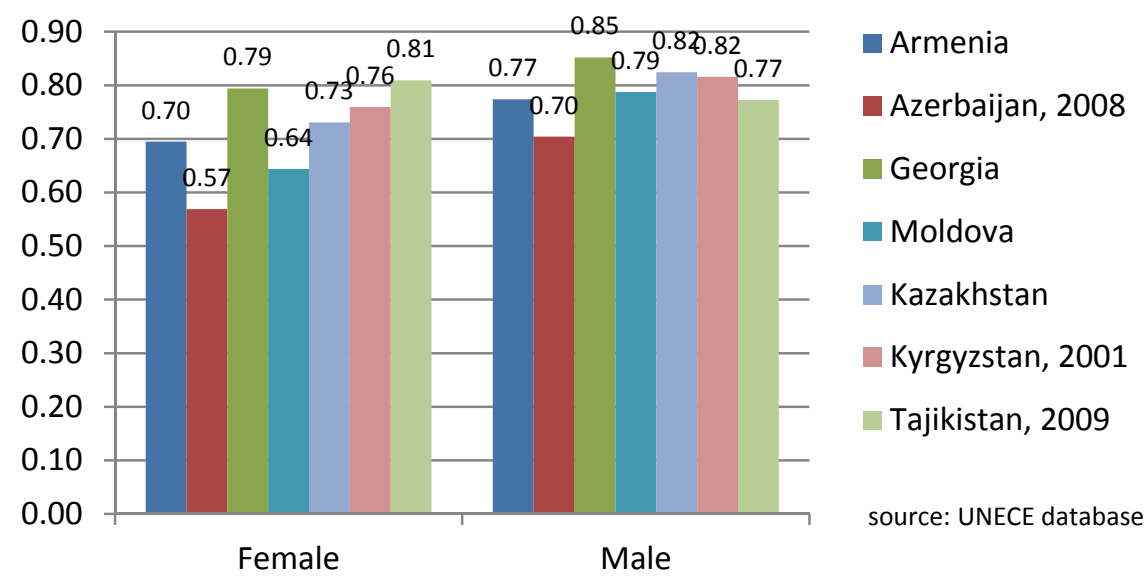

\footnotetext{
${ }^{4}$ Due to the unavailability of gender disaggregated data on private sector employment in the UNECE database, we attempted to use the data available in National Statistical Committee of the Republic of Belarus (2010) and State Statistics Service of Ukraine (2012). However, the data from Belarus excludes individual entrepreneurs and persons working for them, persons engaged in personal agricultural plots, and small businesses that employ 15 or fewer employees. According to Smallbone and Welter (2010), the number of registered own-account workers was about 212,000 and the number of small and medium-sized enterprises (SMEs) was about 440,000 in the country of ten million people. The data for Ukraine did not have the private/public breakdown.
} 
Countries with high shares of private sector employment have not necessarily been more successful at improving their labor market conditions. This has been to some degree because their private sector employment has been dominated by own-account and contributing family workers. Nevertheless, the high share of self-employment in many countries of the region can be viewed as an indication of lively entrepreneurial activity.

Drawing on the data from the Global Entrepreneurship Monitor survey available for Georgia, the established business ownership rate ${ }^{5}$ in 2014 was 7.3 percent and the entrepreneurial intention rate $^{6}$ was 16 percent. Kazakhstan and Russia are the only other former Soviet countries for which these data are available and in these countries the business ownership rate and the entrepreneurial intention rate were 7.4 and 8.1 percent and 3.9 and 2.4 for Kazakhstan and Russia, respectively. By comparison, in the United Kingdom, these rates were 6.5 and 6.3 percent. Hence, the region indeed boasts an active entrepreneurial culture. However, the main question remains whether the entrepreneurial intention and activity can become a seedbed for innovation and job growth and whether women can play a prominent role in this process.

Women have engaged in entrepreneurial activities in different roles. Measuring their engagement by formal business ownership, their ownership participation rate stands at one-third or higher in all countries of the region except for Armenia and Azerbaijan, according to the World Bank Enterprise Survey data. These rates are in line or higher than the OECD average of about 30 percent (OECD 2012). Aculai (2009) confirms the high share of female ownership participation in Belarus, citing the value of about 50 percent. ${ }^{7}$ In this group, Azerbaijan has the lowest female business ownership rate at 4.1 percent in 2013.

Female ownership rate tends to vary across the years. This may reflect a high turnover of firms, although the sharp increase in 2008 and 2009 may also be due to the disproportionately strong impact of the recession on male-dominated industries, such as construction and transport in the

\footnotetext{
${ }^{5}$ Business ownership rate is the percentage of the population aged 18-64 who are currently an owner-manager of an established business, i.e., owning and managing a running business that has paid salaries, wages, or any other payments to the owners for more than 42 months.

${ }^{6}$ Entrepreneurial intention rate is the percentage of the population aged 18-64-individuals involved in any stage of entrepreneurial activity excluded - who are latent entrepreneurs and who intend to start a business within three years. ${ }^{7}$ However, this value has to be interpreted in the context of a very small number of SMEs in Belarus. In 2008, there were about 440,000 SMEs in the country of ten million people (Smallbone and Welter 2010).
} 
region. Only in the case of Azerbaijan do we observe a consistent decline from 14.7 percent in 2005 to 4.1 percent in 2013.

Whereas female ownership rates are relatively high, their proportions of being a top manager are much lower (figure 14). For example, in Kyrgyz Republic in 2013, 49.4 percent of firms had female participation in ownership but only 28.8 percent had a female top manager. In Belarus, 32.7 percent of the small and medium-size firms (SMEs) had a female top manager while 43.6 percent of firms had female majority ownership. Nevertheless, the percentage of firms with female top managers considerably increased in Armenia, Belarus, Georgia, Moldova, Kyrgyz Republic, and Uzbekistan and reached one-third of managers of formal SMEs in 2013 in Georgia, Belarus, and Kyrgyz Republic, which indicates a greater involvement of women in the formal sector of these economies.

Female-managed firms differ from male-managed firms in a number of ways. They tend to be smaller in size: for example, in 2009 in Ukraine, 38 percent of small firms were managed by females, compared to 17 percent of medium firms and 12 percent of large firms. This is so even though they have greater scale economies, which suggests that they would benefit from expansion more than male-managed firms. Their smaller size is largely responsible for the weaker financial performance of female-managed firms (Sattar 2012). At the same time, femalemanaged firms tend to hire proportionately more full-time female workers. For example, in 2009 in Georgia, almost 60 percent of full-time workers in firms with female participation in ownership were female compared to 31 percent in the firms without female participation in ownership. Hence, the expansion of female-managed firms may generate more female jobs.

The World Bank Enterprise Survey data analyzed above reflects the labor market dynamics as they pertain to the small and medium-size enterprises in the formal sector. However, a large share of SME and own-account business activity in these countries occurs in the informal sector. According to Schneider et al. (2010), in 2006 the size of the informal economy in these countries varied from the low of 46 percent in Moldova to the high of 71.1 percent in Georgia (figure 15). The evidence on the female participation in the informal SME sector suggests mixed results. For example, the results of a survey covering formal and informal enterprises in Georgia indicate that 
about 30 percent of SMEs in Georgia are female-owned, almost identical to the results from the World Bank Enterprise Survey data (Academic Swiss Caucasus Net [ASCN] 2014). Gender breakdown of the category of employers from the Georgian household budget survey, which likely includes owners of SMEs and larger firms in both formal and informal sectors, also suggests that the female share among employers is about 30 percent. These findings indicate that the female SME ownership rates in Georgia are similar in the formal and informal sectors. In the Armenian case, the female share among employers based on the 2013 household survey yields the estimate of 16.2 percent (National Statistics Survey of the Republic of Armenia 2014), which is below the World Bank Enterprise Survey rate of 25.3, potentially indicating that the female SME share in the informal sector in Armenia is below its formal counterpart. Hence, the evidence appears to suggest that female ownership rates in formal and informal sectors in the region might be similar.

Figure 14. Percentage of Firms with Female Ownership and Female Top Manager

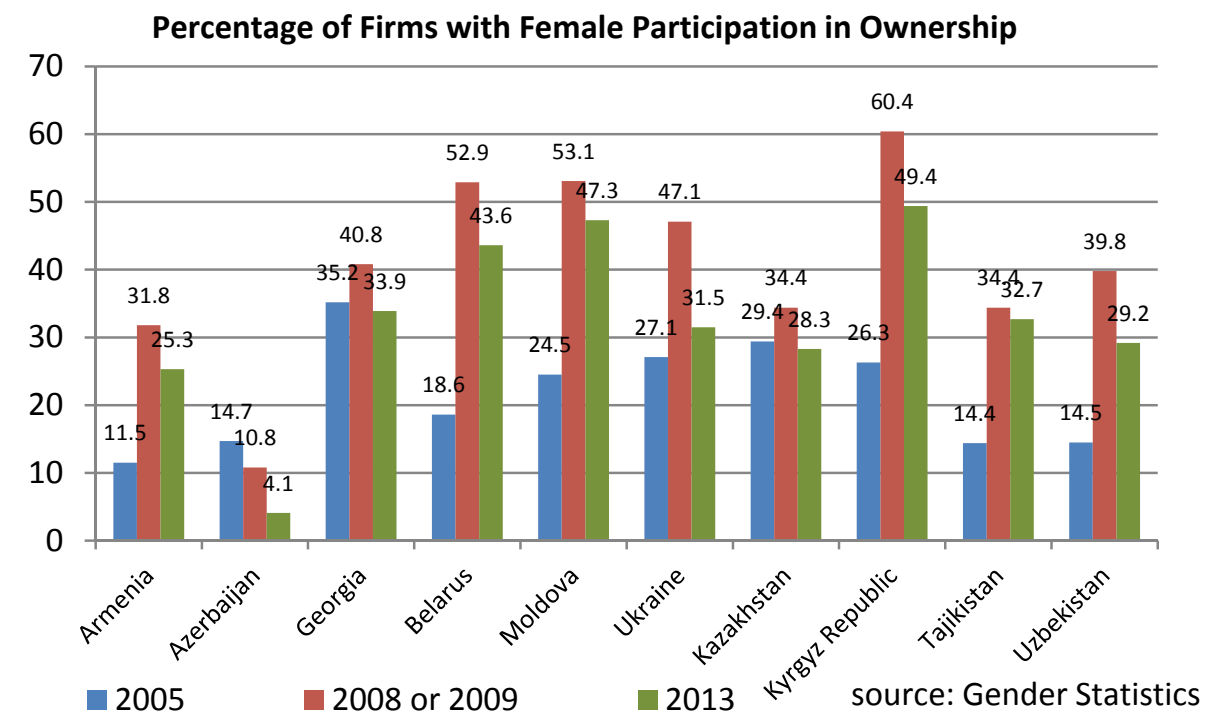




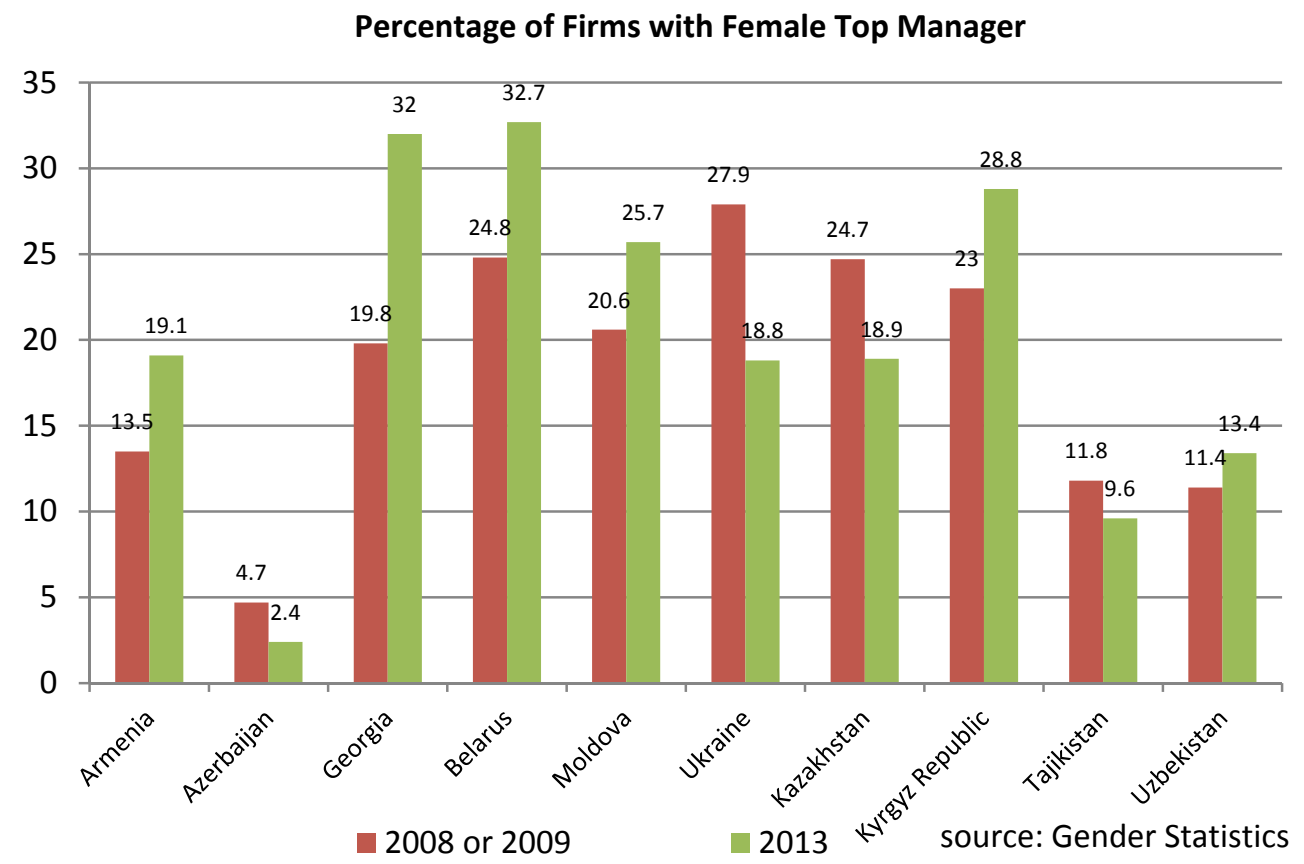

\section{Figure 15. Informal Economy}

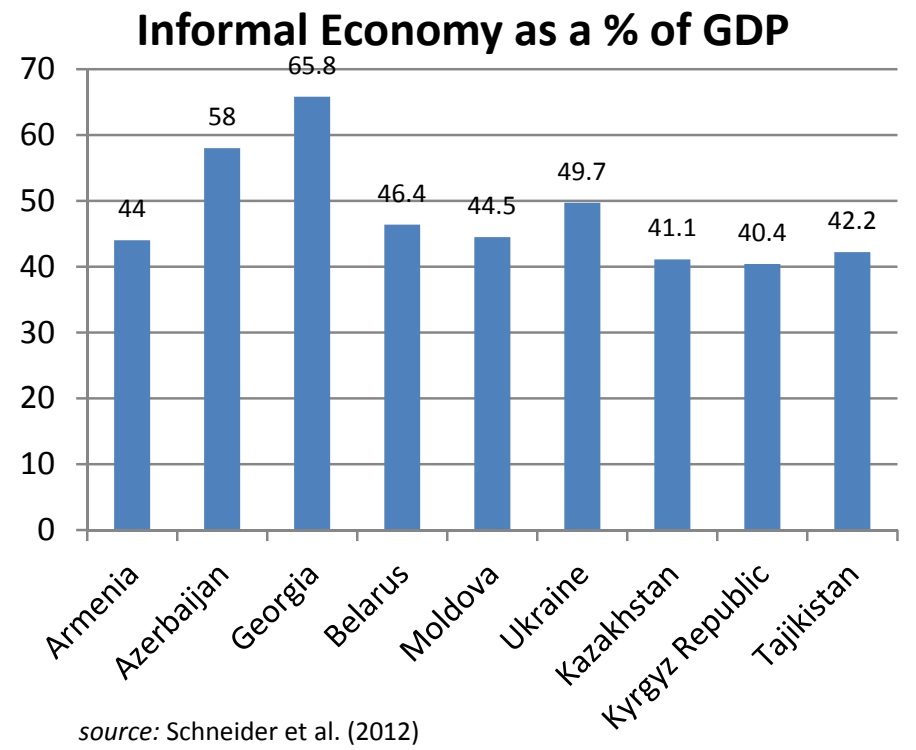

However, the female ownership rates appear to decrease as the firm size increases. The share of women among own-account and contributing family workers is around 50 percent in most countries of the region, 20 percentage points higher than the SME female ownership rates. The female share in self-employment, which is a close proxy for own-account work in Moldova and 
Ukraine, was 42 percent in Moldova in 2010 and 50.3 percent in Ukraine in 2013 (National Bureau of Statistics of the Republic of Moldova 2012; UNFPA 2014). In Ukraine the female share among own-account workers was 50 percent already in the late 1990s, while about 30 percent of enterprises with one to 50 employees were female-owned (Aculai et al. 2009). About 50 percent of own-account entrepreneurs in Georgia are female (ASCN 2014). In Armenia, this proportion stood at a close 46.5 percent in 2013 (National Statistical Service of the Republic of Armenia 2014).

The motivations that lead men and women to become entrepreneurs are important in understanding different dimensions of enterprise performance. According to the World Bank's Enterprise Survey results, the desire to increase income is the primary reason for starting the business for the majority of respondents, followed by the desire to be one's own boss (Kuriakose 2013a, 2013b, 2013c). On the other hand, the majority of the respondents in the ACSN survey in Georgia that included own-account workers and SME owners in formal and informal sectors cite not having a better choice of work as their main motivation, followed by the desire to increase income (ACSN 2014). These findings are consistent with own-account activities being primarily necessity-driven subsistence activities and an alternative to being unemployed. ${ }^{8}$ On the other hand, the SMEs appear to be more likely to be established for reasons associated with opportunity rather than necessity entrepreneurship. Taken together, these findings suggest that relative to men, female entrepreneurship is more likely to represent necessity rather than opportunity entrepreneurship.

The critical question in this context becomes how to turn necessity entrepreneurship into opportunity entrepreneurship with a potential for innovation and job creation. ${ }^{9}$ Women appear to face greater constraints for making this transition and this is one area in which business training appears to have a strong impact on the performance and growth potential of female-owned businesses (Buvinić et al. 2013).

\footnotetext{
${ }^{8}$ Despite this, it is noteworthy that almost 60 percent of the own-account workers and 75 percent of micro- and small-enterprise owners in the ACSN survey state that they would not stop their business in exchange for a fixed salary as an employee.

${ }^{9}$ There is a lot of variation across the countries in terms of innovative capacity. For example, in Armenia almost 50 percent of the formal SMEs allocate funds for research and development, whereas in Georgia and Azerbaijan this share stands at less than 10 percent (Kuriakose 2013b, 2013c).
} 
Access to credit is one factor that may hinder the establishment and growth of female-owned businesses. Women in Moldova and Ukraine report greater difficulties in accessing credit and tend to draw on their personal networks more than men in obtaining credit for establishing or expanding their business (Welter and Smallbone 2010). They also tend to be more risk averse than men, potentially contributing to the gender gap in business-related borrowing, although the evidence linking women's risk aversion to the smaller size of operations is inconclusive (Sattar 2012). According to the findings from the 2014 Global Findex survey, there is a gender gap in the percentage of individuals who report having borrowed to start, operate, or expand a farm or business (figure 16). This is one area in which we observe much bigger gender gaps in Belarus and Ukraine than in the rest of the countries.

Figure 16. Proportion of Individuals Who Borrowed to Start, Operate, or Expand a Farm or Business

Borrowed to start, operate, or expand a farm or business

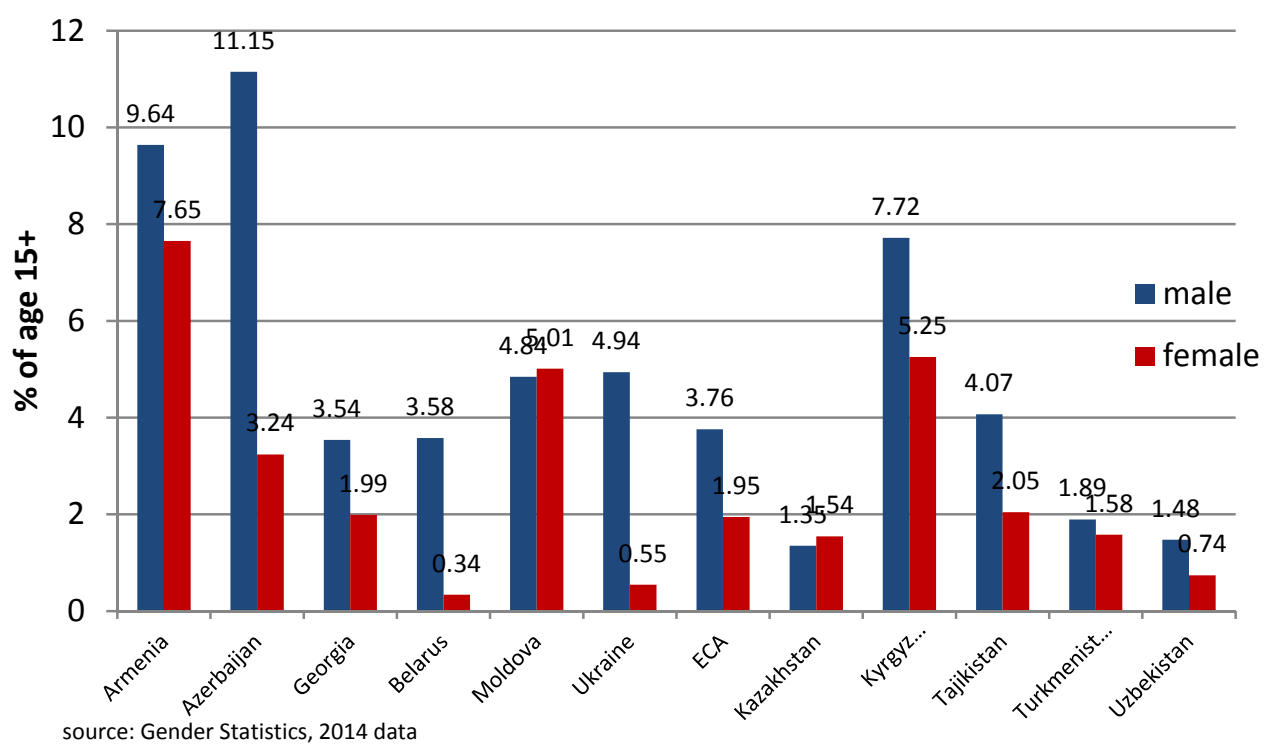

In addition, women have weaker networks to draw upon in establishing and running their businesses. Compared to male networks, female networks are less useful for business development (Welter et al. 2006). In the case of Moldova, weak connections may also have been reflected in the lower probability of female-owned enterprises having been established via privatization (Aculai et al. 2009; National Bureau of Statistics of the Republic of Moldova 2009) although this has been less of a problem in Ukraine (Aculai et al. 2009) and in Georgia, where 25 
percent of privatized businesses in Georgia were female owned (Jashi 2004). Women also face greater regulatory barriers and lack business knowledge relative to men (Sattar 2012).

In part due to these constraints, women-owned SMEs tend to be smaller, even though their returns to scale are substantially larger, suggesting that they would benefit more from expansion. The smaller size translates into weaker overall performance measures even though, according to Sattar (2012), their profitability per unit of revenue is similar to men's. Isakova et al. (2006) finds that in Ukraine women were more likely to break even rather than make a profit, where other studies suggest that once they become entrepreneurs, women's probability of success is as high as that of men (Atasoy 2015).

More work is needed to understand why women are less likely to establish firms with employees, be larger in size, and function in the formal sector compared to men and, more generally, how to turn necessity entrepreneurship into opportunity entrepreneurship. Access to credit, weaker networks, and the lack of business knowledge are some of the constraints that female-headed businesses face. Alleviating these constraints can increase the potential for employment growth via the expansion of female-owned businesses. Indeed, impact evaluation studies suggest a strong positive effect of business and financial literacy programs on the performance of femaleowned businesses. Bruhn and Zia (2013) evaluated the impact of a business and financial literacy program on the firm outcomes of young entrepreneurs in Bosnia and Herzegovina. They find that although the program did not influence business survival rates it had a strong positive impact on business practices, investments, and loan terms for surviving businesses. About 35 percent of the program participants were female and businesses run by women demonstrated additional gains in terms of performance and sales, indicating the program's impact on the size of female-run businesses. These studies also suggest the importance of utilizing multi-pronged methods. For example, providing financial capital has impact on the performance of female-owned businesses when only combined with income-generation training and follow-up activities (Buvinić et al. 2013). Moreover, larger sized female-owned businesses benefit from in-kind capital injections because they are more likely to be invested in the business (Buvinić et al. 2013). The expansion of female-owned businesses may have a particularly strong impact on female employment 
because the female employment rates are higher in the firms owned by women, as the findings of the World Bank Enterprise Surveys demonstrate (Sattar 2012).

\section{RURAL DEVELOPMENT AND AGRICULTURE}

Gender inequities also manifest themselves in rural areas and in agriculture. In all countries of the region, more than a quarter of the population lives in rural areas, with this proportion varying between 25.7 percent in Belarus and 58.5 percent in Moldova. Low productivity agricultural employment dominates rural employment. For example, in Georgia, the share of agriculture in rural employment was 58.3 percent, which is very high compared to other countries of the transition region (FAO 2014). ${ }^{10}$ Such dependence on agriculture reveals the inherent vulnerability of the rural population's livelihood to natural calamities. At the same time, it indicates a strong potential for non-agricultural or agriculture-related development in rural areas, which some of these countries have started to explore. Rural employment is further dominated by informal activities. For example, 81 percent of rural employment in Armenia is informal (UNECE 2012).

Women's role in rural and agricultural employment varies in the region. The female share in the economically active population in agriculture ranges from only 16.2 percent in Armenia to 53.9 percent in Azerbaijan. Such variation may reflect country-level differences in migration from rural areas and in the aging of the population. These differences may also be due to the variation in the reporting of activities on the farm (FAO 2014; Lastarria-Cornhiel 2006). Women's share in the economically active population in agriculture in the region declined between 1995 and 2010. This decline has been partly attributed to the shift in women's activities from paid employment to unpaid activities as a result of the job losses that accompanied land privatization (USAID 2013) and to the higher share of young women leaving rural areas (UNDP, SIDA 2003).

\footnotetext{
${ }^{10}$ The averages are based on nationally representative household survey data for Albania, Bosnia \& Herzegovina, Croatia, Kyrgyz Republic, Macedonia, Poland, Romania, Russia, Tajikistan, Turkey, and Ukraine, representing 74 percent of the region's population.
} 
There are sizable gender differences in the composition of agricultural employment. In Belarus, where wage work is the predominant form of agricultural employment, only 74.1 percent of female agricultural workers are wage workers, compared to 87.3 percent of male agricultural workers (National Statistical Committee of the Republic of Belarus 2010). In Armenia, Azerbaijan, Georgia, and Moldova own-account farmers and contributing family workers constitute a large share of agricultural employment. This share is higher for women than for men. During 2004-2011, 72.41 percent of Georgian women employed in agriculture were contributing family workers compared to only 38.4 percent of men. Miluka (2009) finds that rural men in Moldova are more likely to work in agricultural enterprises as wage workers. This evidence is also corroborated by 5.28 percent of Georgian men in agriculture being wage workers as opposed only 1.5 percent of women. Therefore, overall female agricultural workers tend to hold less desirable forms of employment.

Women and men also tend to engage in different agricultural activities. For example, women in rural areas in the southwestern part of Georgia are primarily occupied in low-value-added cattle farming and dairy production (Walker et al. 2014). The 2009 Moldovan farm survey results indicate that about 75.4 percent of women considered vegetable cultivation as their primary responsibility whereas 65.7 percent of men viewed the substantially higher-value-added vineyard cultivation as such (Grigsby et al. 2012). In a related finding, the results of a 2013 agricultural survey in Georgia indicated that 1.5 percent of men in rural areas were engaged in agricultural processing activities compared to only 0.6 percent of women (Pellillo et al. 2014).

The available data also reveals gender gaps in the average land holding size with women managing smaller plots than men. In Moldova, the average size of men's plot is 1.21 hectares compared to 0.86 hectares managed by women (National Bureau of Statistics of the Republic of Moldova 2014a). In Georgia, women's proportion of land holdings (owned and leased) in terms of the total land in 2013 was 19 percent, which, relative to the ownership shares, suggests that women's plots are smaller than men's. 
Table 1. Selected Data on Women's Labor Market Participation and Remuneration

\begin{tabular}{|c|c|c|c|c|c|c|c|c|c|c|c|c|c|}
\hline & \multicolumn{2}{|c|}{$\begin{array}{l}\text { Female } \\
\text { share of pop }\end{array}$} & \multicolumn{2}{|c|}{$\begin{array}{l}\text { Rural share } \\
\text { of pop }\end{array}$} & \multicolumn{2}{|c|}{$\begin{array}{l}\text { Female } \\
\text { share of } \\
\text { economically } \\
\text { active } \\
\text { population }\end{array}$} & \multicolumn{2}{|c|}{$\begin{array}{l}\text { Female } \\
\text { share of } \\
\text { economically } \\
\text { active pop in } \\
\text { ag }\end{array}$} & \multicolumn{2}{|c|}{$\begin{array}{l}\text { Ag share of } \\
\text { economically } \\
\text { active } \\
\text { women }\end{array}$} & $\begin{array}{l}\text { Share } \\
\text { of rural } \\
\text { hh that } \\
\text { are } \\
\text { female } \\
\text { headed } \\
\text { latest }\end{array}$ & $\begin{array}{l}\text { Female } \\
\text { share } \\
\text { of ag } \\
\text { holders }\end{array}$ & $\begin{array}{l}\text { Gender } \\
\text { wage } \\
\text { gap in } \\
\text { ag }\end{array}$ \\
\hline Armenia & 52.6 & 53.4 & 33.7 & 36.3 & 48.4 & 50.2 & 25.9 & 16.2 & 8 & 3 & 33.1 & 30.0 & 91.4 \\
\hline Azerbaijan & 51.1 & 51.1 & 47.8 & 47.8 & 47.3 & 47.9 & 53.8 & 53.9 & 33.1 & 25.6 & 24.4 & & 105.4 \\
\hline Georgia & 52.5 & 53.0 & 46.1 & 47.0 & 47.1 & 46.7 & 42.3 & 36.2 & 20.5 & 11.7 & & 29.1 & 76.6 \\
\hline Belarus & 53.1 & 53.5 & 32.1 & 25.7 & 48.4 & 49.1 & 28.8 & 18.7 & 9.6 & 3.4 & & & 92.5 \\
\hline Moldova & 52.2 & 52.5 & 53.7 & 58.8 & 48.7 & 52.6 & 37.2 & 30.0 & 21.0 & 8.5 & 30.8 & 36.3 & $76.1^{a}$ \\
\hline $\begin{array}{l}\text { Ukraine } \\
\text { Tajikistan } \\
\text { Kyrgyzstan }\end{array}$ & 53.6 & 53.9 & 33.0 & 31.9 & 50.0 & 49.7 & 37.4 & 27.4 & 12.6 & 5.7 & 47.9 & $\begin{array}{l}17.1 \\
12.4\end{array}$ & 77.6 \\
\hline
\end{tabular}

Source: FAO (2011); "Men and Women" publications for each country; " average for the economy.

On the other hand, the analysis of the gender gap in agricultural wages suggests moderate levels of inequality, likely because agricultural wages are low to begin with. Such analysis is of particular relevance in Ukraine and Belarus, in which the proportion of wage employment in agriculture is high. The data indicate that in Belarus, the gap in agriculture is negligible with women earning 92.5 percent of men's wages whereas in Ukraine it is more sizable with women earning 77.6 percent of men's wages.

Gender gaps in land ownership are particularly high in Central Asia. In Georgia, Armenia, and Moldova, around 30 percent of land holders are female whereas this rate is only 17.1 percent in Tajikistan and 12.4 percent in the Kyrgyz Republic, according to the FAO Gender and Land Rights Database. Female land holders tend to be older than male land holders. In 2013, in Georgia, 66 percent of female land holders were 60 years or older compared to 42 percent of men. Similarly, in Moldova in 2011, 33 percent of female land holders were 65 years or older compared to 15 percent of male land holders (National Bureau of Statistics of the Republic of Moldova 2014a). 


\begin{abstract}
Box 1. Gender Disparities in Agriculture in Moldova
The data from the 2011 General Agricultural Census of the Republic of Moldova documents in greater detail gender disparities in rural women's access to assets, inputs, and services. Women hold about one-third of the agricultural holdings in Moldova with their share ranging from 33 percent in UTA Gagauzia Region to the high of 41 percent in the Chisinau Municipality. The majority of male holders are 45-54 years old whereas the majority of female land holders are 65 years old and above. In fact, in the oldest group women outnumber men. The vast majority of land holders have no education in agriculture, with this proportion slightly higher for females at 82.2 percent compared to men's 79.5 percent. Their time allocation differs as well. Women spend less time on agricultural activities than men do with 12.7 percent of women working eight hours or more compared to 15 percent of men. Women are also less likely to work as permanent or temporary workers on others' land holdings, as only 39 percent of permanent and temporary workers are females. Similar to nonagricultural entities, women manage smaller plots of land than men and on average have less livestock than men do. Furthermore, women own less than 12 percent of agricultural machinery and are less likely to produce crops for sale. In fact only 18 percent of female land holders produce industrial crops compared to 26 percent of male land holders. On the other hand, female land holders are more likely to be engaged in vegetable production. The majority of land of both men and women are occupied by cereal crops. Only about 1.6 percent of land holders are involved in gainful nonagricultural activities and among them less than 30 percent are female. This data reveals the presence of gender gaps in many aspects of agricultural production.
\end{abstract}

Source: National Bureau of Statistics of the Republic of Moldova (2014a)

In sum, the picture of gender disparities in rural areas and in agriculture in the region reveals that women are more likely to engage in low-value-added agricultural production compared to men. Similar to nonagricultural sectors, women operate on a smaller scale compared to men.

Moreover, in the countries with a small share of wage employment in agriculture, women are more likely to work as contributing family workers. For these countries, in particular, the challenge lies in improving income-earning opportunities of women. Impact evaluation studies indicate that female farmers in countries with small-scale agriculture benefit from an integrated suite of services that targets production, marketing, and social constraints and from the creation of farmer groups and collectives to establish and strengthen networks (Buvinić et al. 2013, 5). Providing female-targeted agricultural education services and training in the use of modern agricultural inputs (such as seeds and fertilizers) and livestock has also been found to be a promising avenue for raising the productivity of female farming (USAID 2013). 


\section{GENDER PAY GAPS}

The analysis of gender pay gaps further contributes to our understanding of the disparities in labor market outcomes. We observe a large variation in the gender pay gap ${ }^{11}$ with a visible difference between the more equal Western CIS countries and the less equal South Caucasus and Central Asian countries (figure 17). There is a general downward trend in the magnitude of the gap since 2000 in all countries, except for Belarus, Azerbaijan, and Tajikistan, in which the gap increased. Pastore and Veraschagina (2011) attribute the rising gender wage gap in Belarus to the growing industrial segregation. In Azerbaijan, the spike in the gender pay gap observed since 2009 is particularly sharp. Kazakhstan stands out as a country with a very low and declining gender wage gap that reached less than 10 percent, using the UNECE data. However, these numbers have to be interpreted with caution as other sources find that the gender wage gap in monthly wages was above 30 percent and decreased from 39.3 percent in 2003 to 31.4 percent in 2008 (van Klaveren et al. 2010).

\section{Figure 17. Gender Pay Gap}

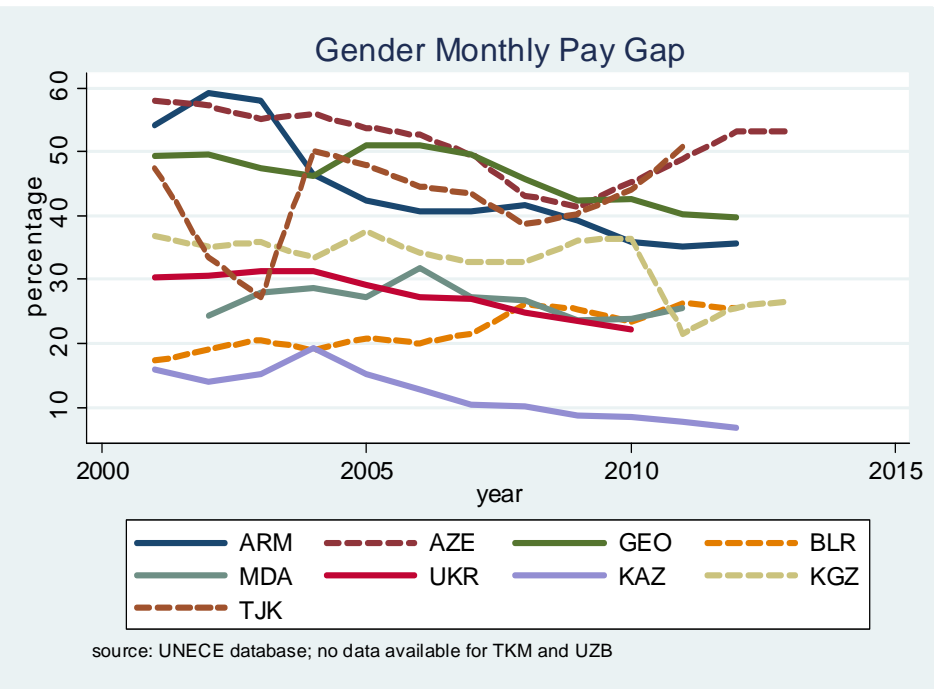

\footnotetext{
${ }^{11}$ We defined the gender pay gap as the difference between men's and women's average earnings from employment expressed as a percentage of men's average earnings.
} 


\section{Figure 18. Gender Pay Gap and Earned Income Gap}

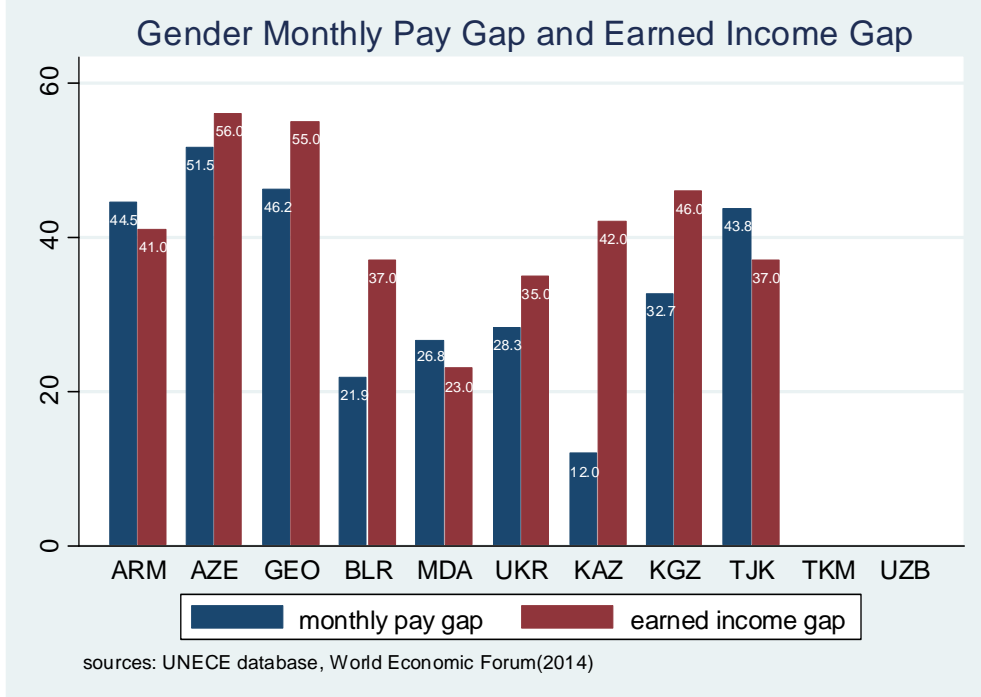

The gender pay gap in the region can be partly attributed to the industrial and occupational segregation and fewer hours of employment among women, although the majority of the gap remains unexplained, arguably due to discrimination in the labor markets (Sattar 2012). Gang (2014) finds that the migration of men has substantially contributed to the contraction in the gender wage gap at the mean that took place in Tajikistan. Beyond the analysis of the gap at the mean of the distribution, we find the presence of the changes in the shape of the gender gap across pay distribution. Ganguli and Terrell (2006) find that the contraction in the gender wage gap in Ukraine that took place between 1986 and 2003 was primarily caused by the reduction in the gender wage gap at the bottom of the distribution. On the other hand, Pignatti (2012) assesses a more recent 2003-07 period in Ukraine and finds that the continued contraction in the gap was driven by the drop in the upper part of the distribution, highlighting a shift that appears to have taken place between the two periods. Khitarishvili (2013) finds that the contraction in the gender wage gap in Georgia between 2004 and 2007 took place primarily at the top of the distribution, driven by rising wages in the public sector. After 2008, on the other hand, the reduction took place primarily at the bottom of the distribution due to the impact of the 2008 recession. In contrast to the contractions in Ukraine and Georgia, Pastore and Verashchagina (2011) demonstrate that the gender wage gap in Belarus more than doubled between 1996 and 2006 and did so mostly at the bottom of the distribution. This increase was due to the higher level of industrial segregation. Hence, the empirical evidence reveals a range of outcomes in the changes 
in the distribution of the gender wage gap in the transition region, underscoring the complex interplay between economic and institutional mechanisms. Nevertheless, a large portion of the gender wage gap remains unexplained, potentially indicating the presence of labor market discrimination.

Gender pay gap analysis provides only a partial picture of the gender earnings gaps in countries in which wage employment is not the dominant form of employment, as is the case for the countries of Central Asia and South Caucasus. Difficulties with earnings measurement among own-account workers and a high proportion of contributing family workers in these countries highlight the need to evaluate gender gaps using other measures.

To that end, we supplement the gender pay gap numbers with the gender earnings gap using earned income estimates from the World Economic Forum (2014). Azerbaijan and Georgia remain the most gender unequal countries (table 2). However, the rankings of other countries change. For example, Tajikistan is tied in the third place with Belarus. We also consider the measure of wage equality for similar work, which reveals very similar levels of inequality. This particular measure seems to indicate that the extent to which gender discrimination may be responsible for the gender gap appears to be similar among these countries. This finding suggests that the main reason for cross-country variation likely lies in the differences in observed characteristics, such as industrial and occupational segregation and potentially hours of work. 
Table 2. Different Measures of Gender Gap in Earnings

\begin{tabular}{llll}
\hline & $\begin{array}{l}\text { Gender Pay Gap } \\
\text { (UNECE, 2012) }\end{array}$ & $\begin{array}{l}\text { Earned Income Gap } \\
\text { (WEF,2014) }\end{array}$ & $\begin{array}{l}\text { Wage Equality for Similar } \\
\text { Work, F/M ratio (WEF, 2014) }\end{array}$ \\
\hline Armenia & $35.6(6)$ & $41(4)$ & .66 \\
Azerbaijan & $53.2^{1}(9)$ & $56(8)$ & .74 \\
Georgia & $39.8(7)$ & $55(7)$ & .72 \\
Belarus & $25.5(3)$ & $37(3)$ & \\
Moldova & $25.6^{2}(4)$ & $23(1)$ & .70 \\
Ukraine & $22.2^{3}(2)$ & $35(2)$ & .69 \\
Kazakhstan & $6.8(1)$ & $42(5)$ & .71 \\
Kyrgyz Republic & $26.7^{1}(5)$ & $46(6)$ & .72 \\
Tajikistan & $50.9^{2}(8)$ & $37(3)$ & .71 \\
\hline
\end{tabular}

Notes: $2013^{1} ; 2011^{2} ; 2010^{3}$; no data available for Turkmenistan and Uzbekistan.

\section{HUMAN CAPITAL}

School enrollment rates in the South Caucasus and Western CIS are generally high among boys and girls and there is close to full gender parity at the primary and secondary levels (figures 19 and 20). However, the situation in Central Asia and especially in Tajikistan is particularly worrisome as girls' enrollment rates are substantially lower than boys'.

At the secondary level, girls tend to outperform boys, with the magnitude of the gap being smaller in mathematics and larger in reading and science. This holds for all countries in the region that have participated in the Programme for International Student Assessment (PISA), including Azerbaijan, Georgia, Moldova, Kazakhstan, and Kyrgyz Republic. However, the gap varies across the performance distribution: it is large favoring girls at the lower end and either disappears or favors boys at the upper end, especially in mathematics (Stoet and Geary 2015). Factors contributing to these differences in the gender gap across the performance distribution and their implications for the career paths of boys and girls have not been sufficiently analyzed. 


\section{Figure 19. Trends in the Ratio of Female-to-Male Enrollment}

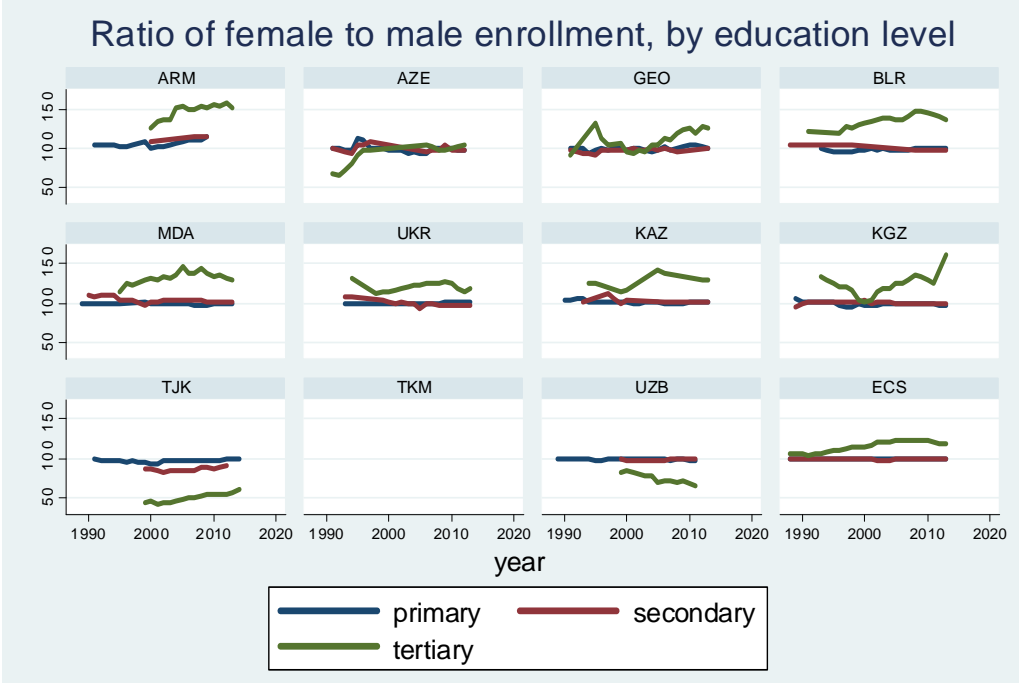

source: Gender Statistics

Figure 20. Ratio of Female-to-Male Enrollment

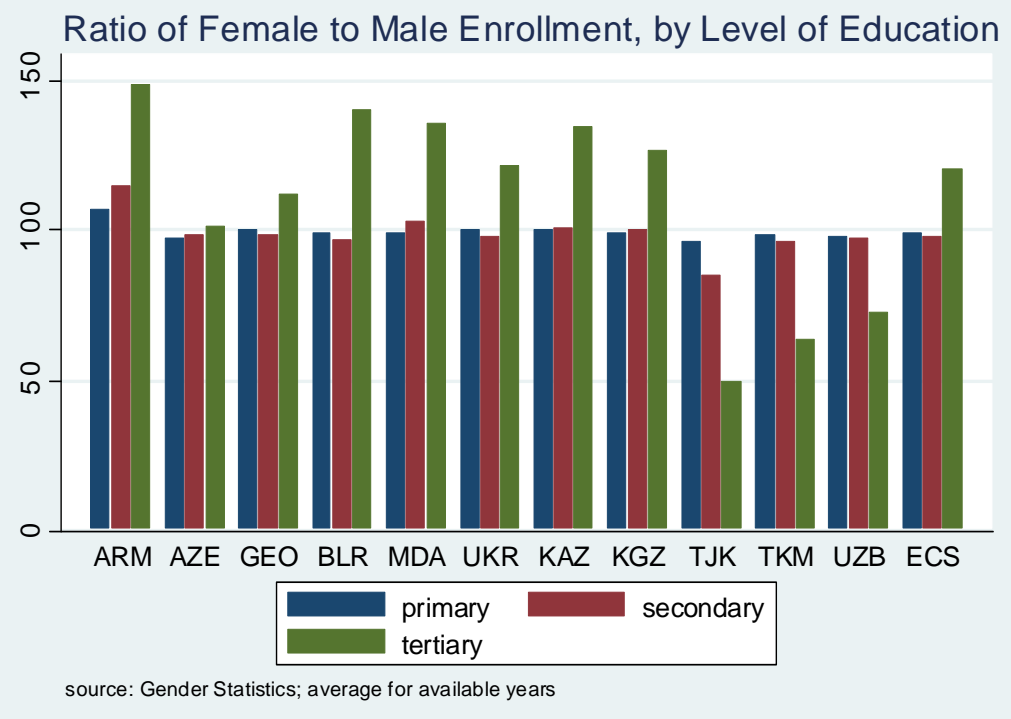

At the tertiary level, women represent the majority of students in most countries of the region, including the South Caucasus, Western CIS, Kazakhstan, and Kyrgyzstan. In Tajikistan, Turkmenistan, and Uzbekistan, it is young men who represent the majority. Azerbaijan has made strong gains in the female share of tertiary students reaching parity at the beginning of 2000 s. 
This picture at the tertiary level masks a high degree of specialization by subjects. It has been well established that gender differences in the fields of study translate into gender differences in labor market outcomes in the form of industrial segregation and gender wage gaps (Flabbi 2011). Therefore, understanding and addressing the factors contributing to gender asymmetries in the educational composition of tertiary education today is imperative to reducing the industrial segregation by gender and wage gaps tomorrow. ${ }^{12}$ We observe that in the majority of countries women represent more than 70 percent of graduates in education and more than 65 percent of students in health and welfare (figure 21 ). ${ }^{13}$ In this region women are significantly underrepresented in engineering, manufacturing, and construction, especially in Azerbaijan, where less than 20 percent of tertiary students in these subjects are female (Sattar 2012). Women also tend to be underrepresented in agriculture (figure 22). There is considerable variation by country in social studies, business and law, and science, with the share varying from about 23 percent in Uzbekistan to about 75 percent in Belarus. On the other hand, women are about evenly represented in the sciences (figure 23). Except for the latter finding, the gender picture of specialization by subject is similar to the findings from European countries (Flabbi 2011).

Figure 21. Share of Female Graduates in the Subjects in Which They Are Overrepresented

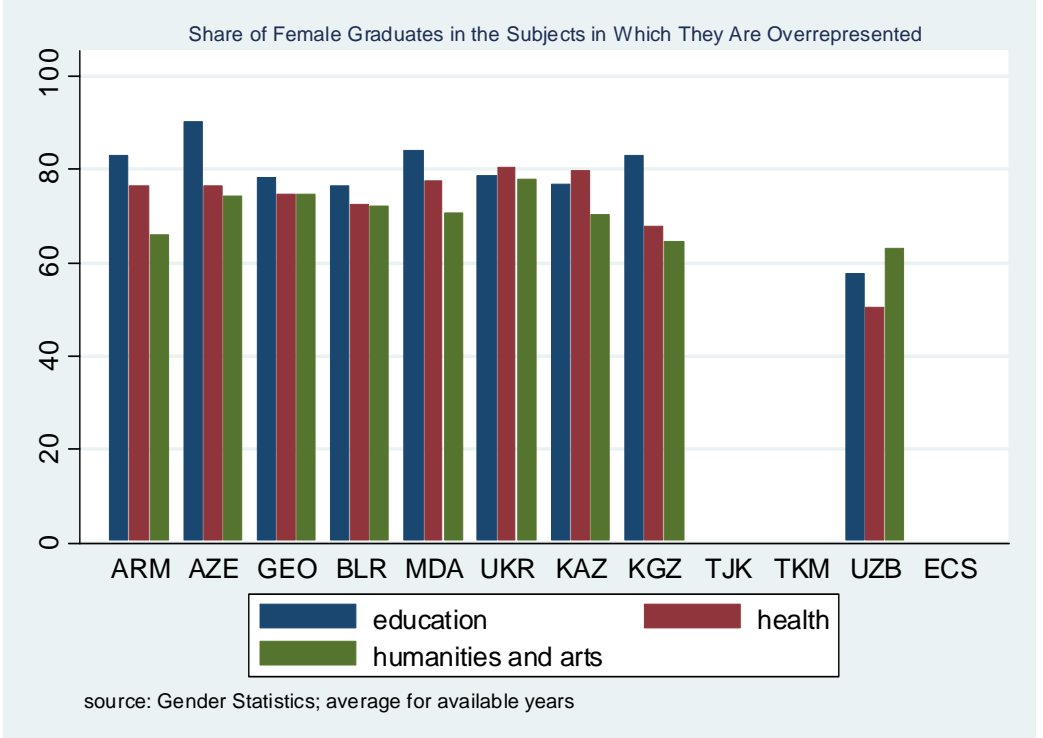

\footnotetext{
${ }^{12}$ Recent studies suggest that individual relative strengths in subjects may influence future academic choices. Given that girls tend to have comparative advantage in verbal rather than mathematics competencies (i.e., relative to boys girls are much better in reading than in mathematics), their academic choices may in part reflect this advantage (Stoet and Geary 2015).

${ }^{13}$ The data for Moldova are unavailable.
} 
Figure 22. Share of Female Graduates in the Subjects in Which They Are Underrepresented

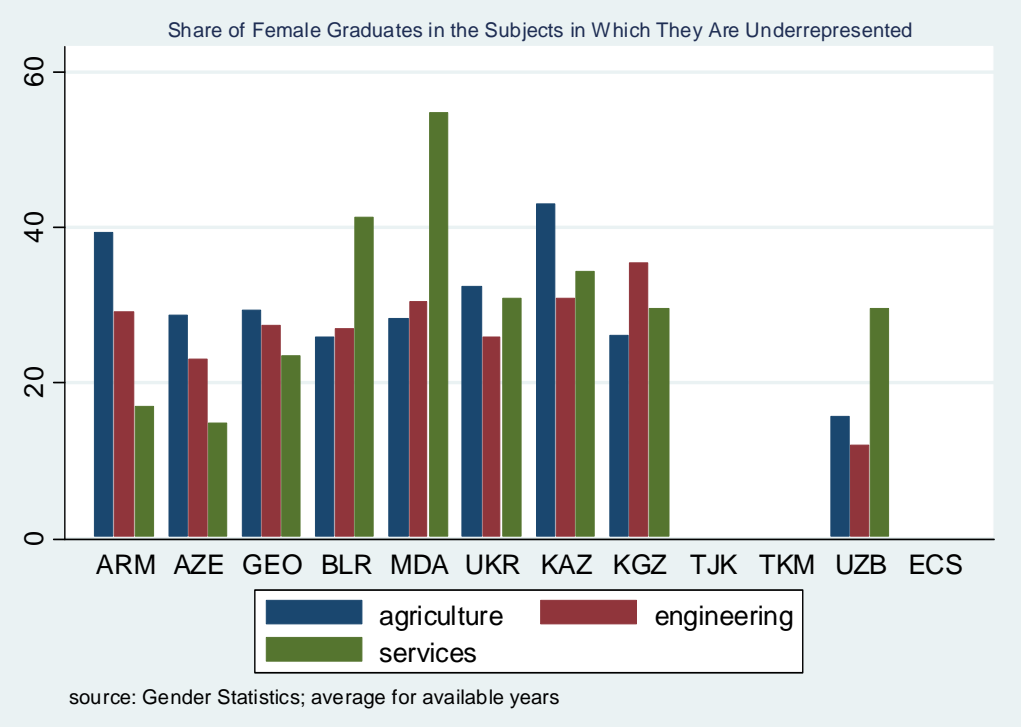

Figure 23. Share of Female Graduates in Sciences and Social Science

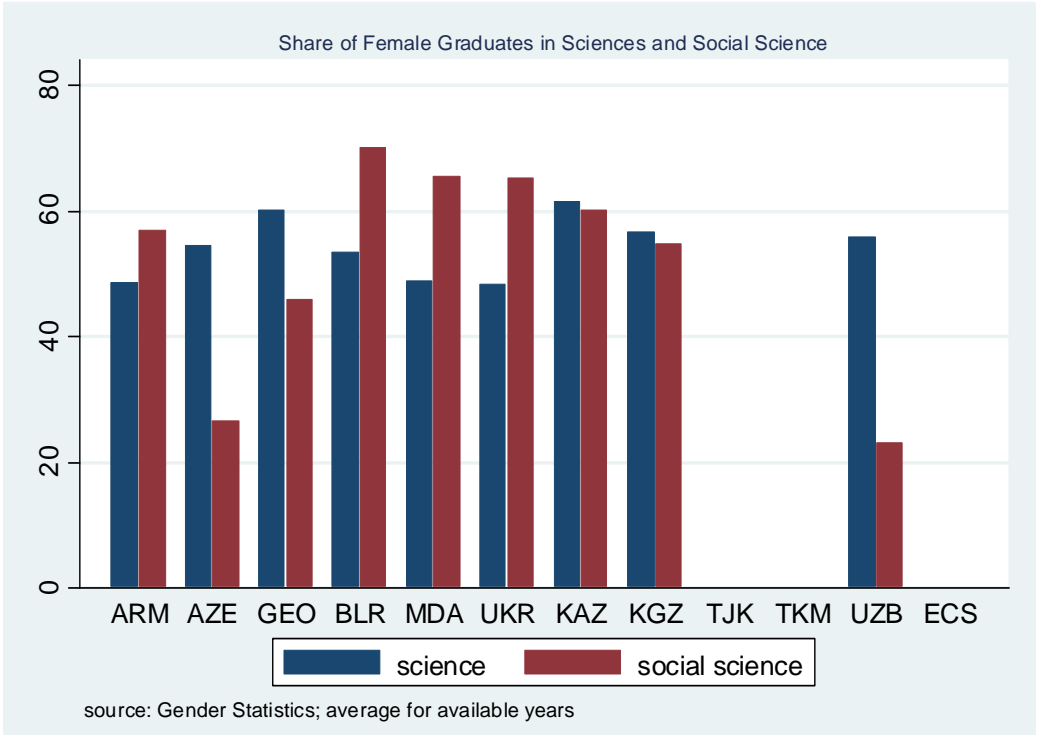

One of the most pressing labor market challenges of the region lies in the mismatch between the skills and training received at tertiary institutions and those demanded by the economy. It is a striking fact that despite a high share of the workforce with tertiary education, employers in these countries consistently cite inadequate skills of workers as a major obstacle to the operation and growth of their enterprises (Rutkowski 2013). Using the data from the World Bank's Skills 
Toward Employment and Productivity (STEP) survey for Armenia, Georgia, Macedonia, and Ukraine, Kupets (2015) investigates the incidence and determinants of the education-job mismatch. She finds that 30 percent of urban workers in Armenia, Georgia, and Ukraine are overeducated for their jobs. These rates are comparable to those in more developed economies. However, unlike those economies, in Armenia, Georgia, and Ukraine, the mismatch takes place not only at the beginning of the working life but all throughout it, albeit for different reasons. For older workers, the culprit appears to be the difference between the skills and knowledge acquired during the Soviet period and the current demands of the economies. For younger workers, it is the limited employment opportunities generated by firms to whom having higher education no longer carries accurate signals about workers' abilities. The female incidence of overeducation is higher in Ukraine and lower in Armenia and Georgia. Kupets (2015) suggests that women in Ukraine use education to compensate for their relative lack of experience that stems from their child-rearing responsibilities. In Armenia and Georgia, on the other hand, the traditional male role as a breadwinner may be forcing men to accept jobs for which they are overeducated. Irrespective of their age and educational attainment, the school-to-work transition for girls is almost twice as long as that of boys, largely attributable to young women's child-reading responsibilities (Guarcello et al. 2005).

\section{UNPAID WORK AND CARE}

Similar to women in other countries, women in the countries of the region carry the burden of unpaid labor in the domestic economy, which can constrain their involvement in employment and entrepreneurship. The share of inactive women who report domestic responsibilities as the primary reason behind their inactivity varies from 9 percent in Belarus to 37 percent in Georgia (figure 24). On the other hand, this share is negligible for men in the majority of the countries of the region.

Among entrepreneurs, survey evidence from Moldova indicates that only 6 percent of female entrepreneurs reported not being involved in domestic activities in contrast to 22 percent of 
males. In Ukraine, these numbers stood at 5 percent and 37 percent for female and male respondents, respectively (Aculai et al. 2009).

Time use surveys further illuminate the unequal gender distribution of unpaid work and paid work time (table 3). They demonstrate that women bear most of the burden of unpaid work and confirm the gender disparities in paid work. In Armenia in 2008, women spent five times as much time on unpaid work as men, compared to three times as much time as men in Azerbaijan. On the other hand, in Moldova, they spend one-and-a-half times as much time as men on unpaid work, which is below the OECD average of two. The gender gaps in time use are more pronounced in childcare, possibly because proportionately more women stay at home caring for children. For example, women in Armenia spent six times and in Moldova two-and-a-half times as much time as men taking care of children.

Figure 24. Share of Inactive Population Due to Domestic Responsibilities

Share of Inactive Population due to Domestic Responsibilities

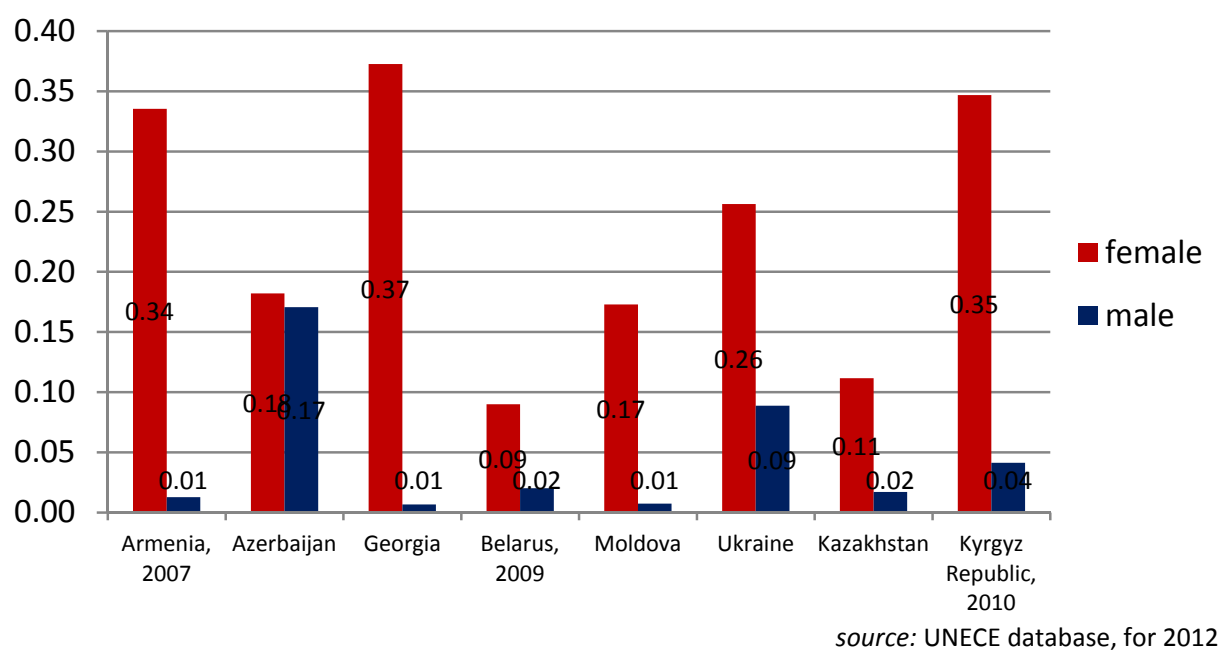

The gender disparity in paid work, too, is higher in Armenia and Azerbaijan and lower in Moldova. Women's work hours are about 79 percent of men's work hours in Moldova, whereas this proportion is 44 percent and 36 percent in Armenia and Azerbaijan, respectively. Despite the potentially positive interpretation of the low gap in time use in Moldova, it appears to be driven by both men and women working fewer hours than in other countries. 
Despite these differences in the gender gaps in unpaid and paid time use among the three countries, the gender gap in total work hours is relatively low in all three countries (OECD 2012). In Moldova, this is because the gender gaps in both paid and unpaid work are low, and in Armenia and Azerbaijan this is because the high gender gaps in unpaid and paid work time mirror each other. Despite the low gender gap, however, women work more total hours than men.

Table 3. Paid and Unpaid Work Time, Daily Hours

\begin{tabular}{|c|c|c|c|}
\hline Time Use & Men & Women & FM Ratio \\
\hline \multicolumn{4}{|l|}{ Paid work and study } \\
\hline Armenia (2004) & 5.4 & 2.1 & 0.39 \\
\hline Armenia (2008) & 5.5 & 2.4 & 0.44 \\
\hline Azerbaijan (2008) & 4.7 & 1.7 & 0.36 \\
\hline Moldova (2011-12) & 3.9 & 3.1 & 0.79 \\
\hline Kyrgyz Republic (2005) & 6 & 4 & 0.67 \\
\hline Kazakhstan (2006) & 5 & 3 & 0.60 \\
\hline Tajikistan (2003) & & 3 & \\
\hline OECD 28 & 5.5 & 3.6 & 0.65 \\
\hline \multicolumn{4}{|l|}{ Unpaid work } \\
\hline Armenia (2004) & 1.1 & 5.8 & 5.27 \\
\hline Armenia (2008) & 1.1 & 5.2 & 4.95 \\
\hline Azerbaijan (2008) & 2.1 & 6.1 & 2.90 \\
\hline Moldova (2011-2012) & 3.0 & 4.6 & 1.52 \\
\hline Kyrgyz Republic (2005) & 2 & 5 & 2.5 \\
\hline Kazakhstan (2006) & 4 & 6 & 1.5 \\
\hline Tajikistan (2003) & & 5.8 & \\
\hline OECD 28 & 2.3 & 4.6 & 2.00 \\
\hline \multicolumn{4}{|l|}{ Childcare, main activity } \\
\hline Armenia (2004) & 0.1 & 0.7 & 7.00 \\
\hline Armenia (2008) & 0.1 & 0.7 & 7.00 \\
\hline Moldova (2011-2012) & 0.3 & 0.7 & 2.3 \\
\hline \multicolumn{4}{|l|}{ Total work } \\
\hline Armenia (2004) & 6.5 & 7.9 & 1.22 \\
\hline Armenia (2008) & 6.5 & 7.6 & 1.17 \\
\hline Azerbaijan (2008) & 6.8 & 7.8 & 1.15 \\
\hline Moldova (2011-12) & 6.9 & 7.7 & 1.11 \\
\hline Kyrgyz Republic (2005) & 8 & 9 & 1.13 \\
\hline Kazakhstan (2006) & 9 & 9 & 1 \\
\hline Tajikistan (2003) & & 8.8 & \\
\hline OECD 28 & 7.8 & 8.2 & 1.05 \\
\hline
\end{tabular}

Note: These values correspond to average time spent on activities, which is the product of the participation rate and the average time spent by those undertaking the activity.

Sources: OECD 2011b; Meurs and Slavchesvka (2014); Statistical Agencies of Azerbaijan and Moldova 
The breakdown by location reveals that the gender gap in time use is lower in rural than in urban areas. The gap is especially prominent in unpaid work time even though rural men and women spend more time on unpaid work time than their urban counterparts (see also Meurs and Slavchevska 2014). This finding does not necessarily imply the bigger sharing of household responsibilities in rural areas but may simply be a reflection of the greater degree of gender specialization in unpaid work activities in rural areas (Walker et al. 2014). On the other hand, the gender gap in childcare is higher in rural areas than in urban areas. A more careful look at the data reveals that this finding is due to men in rural areas being less likely to participate in childcare. The rural men who do participate in childcare spend more time taking care of their children than their urban counterparts. On the other hand, women in rural areas spend less time and are less likely to participate in childcare. In the context of Tajikistan, Meurs and Slavchevska (2014) argue that this may be because poor infrastructure constrains their non-care-related time use and, as a result, their care time suffers. In addition, evidence from Moldova suggests that parents in rural areas spend less time on child enrichment and educational activities than their urban counterparts, potentially negatively influencing their children's development outcomes (National Bureau of Statistics of the Republic of Moldova 2014b). Nevertheless, urban/rural comparisons in childcare have to be made with caution, especially if childcare time use comparisons are made using primary childcare time use because the share of secondary childcare (i.e., childcare that takes place while parents are primarily involved in other activities) may be higher in rural areas. 
Table 4. Rural/Urban Breakdown of Time Use, Daily Hours

\begin{tabular}{|c|c|c|c|c|c|c|}
\hline & \multicolumn{3}{|c|}{ rural } & \multicolumn{3}{|c|}{ urban } \\
\hline & Men & Women & FM ratio & Men & Women & FM ratio \\
\hline \multicolumn{7}{|l|}{ Armenia (2008) } \\
\hline paid work and study & 5.68 & 2.35 & 0.41 & 4.96 & 2.43 & 0.49 \\
\hline unpaid work & 1.47 & 5.93 & 4.03 & 0.83 & 4.88 & 5.88 \\
\hline total & 7.15 & 8.28 & 1.16 & 5.79 & 7.31 & 1.26 \\
\hline primary childcare (AxB) & 0.08 & 0.58 & 7.25 & 0.13 & 0.77 & 5.92 \\
\hline $\begin{array}{l}\text { A: proportion taking care } \\
\text { of children (percent) }\end{array}$ & 8 & 34 & & 15 & 40 & \\
\hline $\begin{array}{l}\text { B: time spent on } \\
\text { childcare by individuals } \\
\text { who take care of } \\
\text { children (hours) }\end{array}$ & 1.1 & 1.75 & 1.59 & 0.93 & 1.93 & 2.08 \\
\hline \multicolumn{7}{|l|}{ Tajikistan (2003) } \\
\hline Paid work & & 3.5 & & & 1.8 & \\
\hline Unpaid work(housework) & & 5.5 & & & 6.5 & \\
\hline Total & & 9 & & & 8.3 & \\
\hline
\end{tabular}

Sources: National Statistical Service of the Republic of Armenia (2008); Meurs and Slavchevska (2014)

In sum, the gender gaps in unpaid and paid time use vary in these countries from high, as in Armenia and Azerbaijan, to moderate, as in Moldova. Furthermore, the gap appears to be smaller in rural areas than in urban areas. Despite these differences, women spend at least as many total hours working as men in all the countries according to the available time use data.

The extent to which care and domestic responsibilities constrain women's engagement in employment and entrepreneurship in the countries of the region needs a careful assessment. The participation of females with children in labor markets depends on the available social infrastructure and on the affordability of market substitutes and there appears to be a strong correlation between the female labor force participation and the availability of a childcare network in the countries of the region. The available data indicate that in Belarus and Ukraine all children three to five years of age are enrolled in pre-school. In Moldova, the enrollment rate stands at 82 percent. The countries of the South Caucasus and Central Asia, on the other hand, trail behind with the pre-primary enrollment rates ranging from about 9 percent in Tajikistan to 63 percent in Turkmenistan (figure 25). 
Figure 25. School Enrollment, 3-5 Year Olds

School Enrollment, 3- 5, preprimary (\% gross)

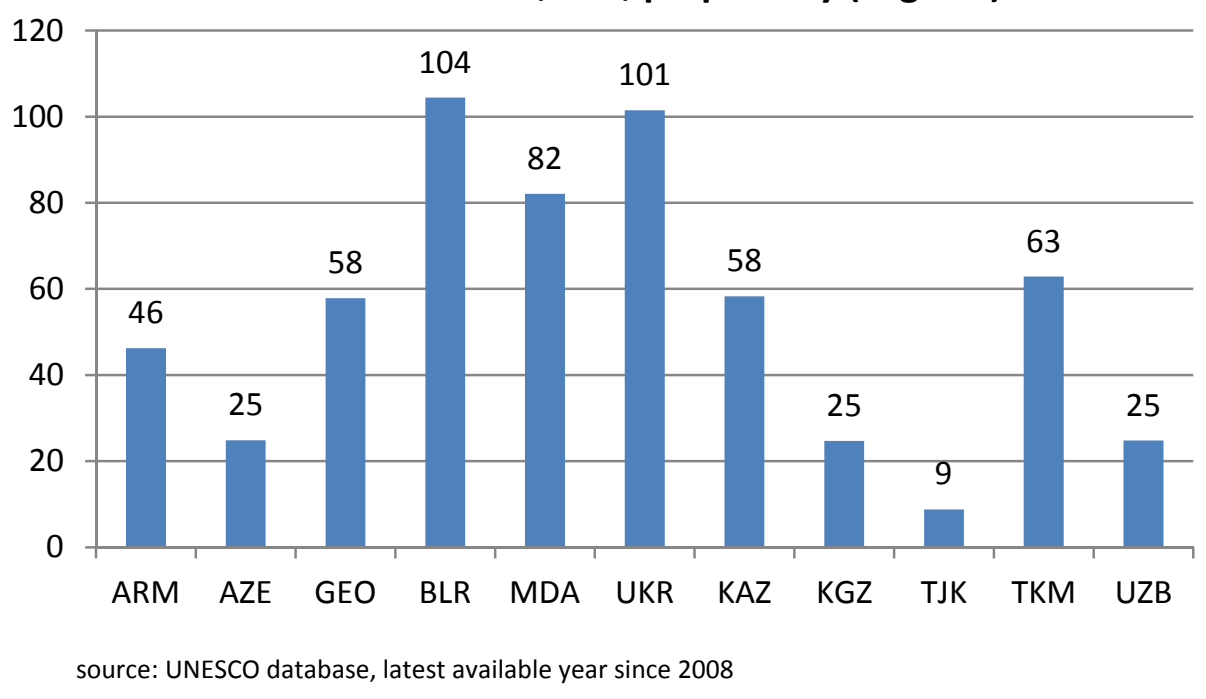

Belarus, Moldova, and Ukraine, together with Kazakhstan, also lead in the daycare enrollment rates of children under 3 (figure 26). Hence, the availability of the universal pre-primary education in Belarus and Ukraine and close to universal pre-primary education in Moldova may have enabled the high wage employment rates among women in these countries. In turn, the lack of a childcare support system in most countries of South Caucasus and Central Asia may be a contributing factor explaining the low proportion of female wage employment. We note that in addition to cross-country variation, there are also sizable differences in the school enrollment rates within the countries. For example, in Moldova in 2012, the gross enrollment rate of rural children 3-5 years old was 71.4 percent compared to 100.5 percent for urban children (National Bureau of Statistics of the Republic of Moldova 2014b). The lower rural enrollment rates are associated with the lower labor force participation rates of rural women compared to urban women in Moldova (33.6 percent compared to 40.4 percent). This observation, combined with the lower amount of time spent by rural parents on enrichment activities with children, may raise concerns about the rural/urban gap in the human capital development of children. 
Figure 26. Enrollment Rate of Children under Three Years Old

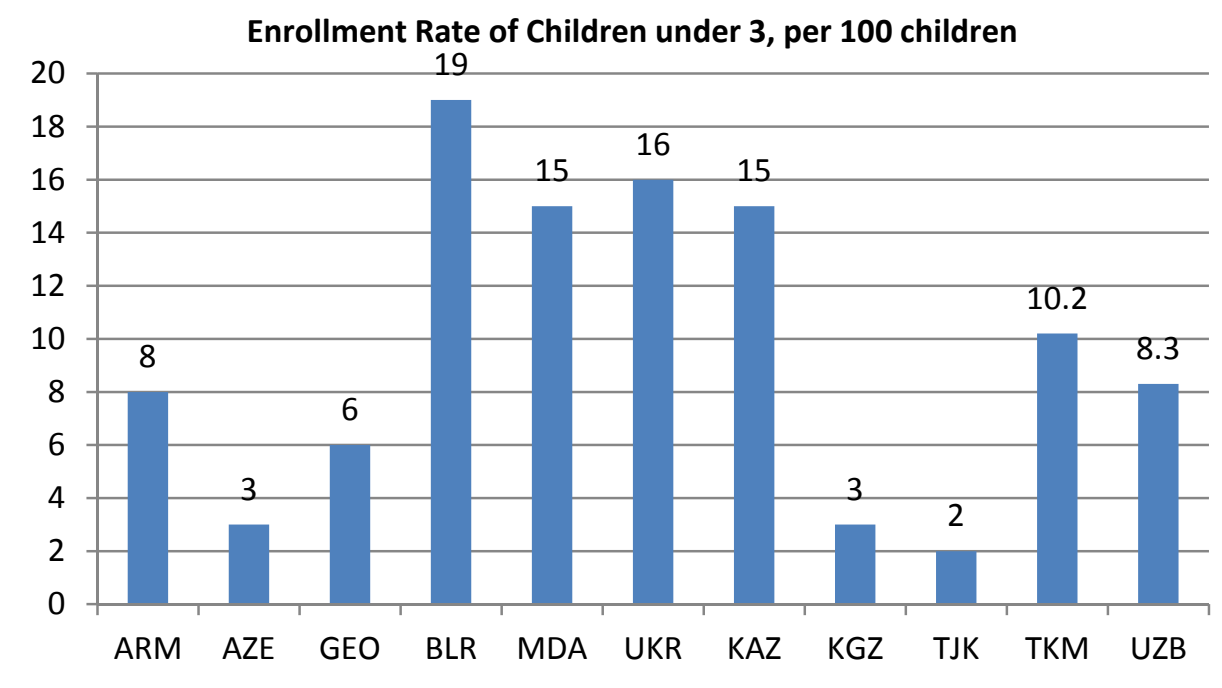

source: UNECE database, latest available year since 2007

A comprehensive review of policies aimed at raising women's economic empowerment finds that programs providing access to affordable and reliable childcare, childcare subsidies, and public childcare provisioning are an effective approach for improving women's labor market outcomes and earnings in developing and transition economies (Buvinić et al. 2013). Fong and Lokshin (2000) find that in Romania providing childcare vouchers increased the number of working mothers and raised household income. Lokshin (2004) compares the impact of family allowances, wage subsidies, and childcare subsidies on maternal employment in Russia. He finds that childcare subsidies are the most effective at increasing maternal employment in terms of the number of work hours and the likelihood of wage employment, and at raising household income.

Evidence is also supportive of the employment-increasing impact of publicly provided preschool programs (Haeck et al. 2015). Such programs have the additional benefit of direct employment creation and the accompanying increase in the demand for supporting jobs. İlkkaracan et al. (2015) and Antonopoulos and Kim (2011) investigate the direct and indirect effects of social care sector expansion and find that it supports decent employment creation, generates pro-women job allocation, and reduces poverty. 
The effect of childcare provisioning is positive not only on paid female employment, but also on female entrepreneurship, as it allows women to expand their businesses and hence address the small size constraint, which is one of the main reasons for the weaker performance of femaleowned businesses (Johnson 2005).

Therefore, policies supporting the development of the childcare support network can play a considerable role in increasing female wage employment and entrepreneurship.

\section{MIGRATION}

Migration has enabled many households to escape poverty and sustain their livelihoods. The gender makeup of migrants varies by country. Long-term migration is a mostly female phenomenon in Azerbaijan, Kyrgyzstan, Uzbekistan, and Moldova, whereas in Armenia and Georgia, the majority of long-term migrants have been men $^{14}$ (figure 27). With the exception of Belarus, long-term migration has become more feminized. Behind this broad picture lies wide variation in the gender makeup by the destination of migrants, as well as their regional origin within countries. For example, in contrast to the overall dominance of female migrants in the case of Moldova, the Moldovans in Italy are predominantly men (Marchetti et al. 2014). At the same time, although men are more likely to emigrate in Georgia than women, Zurabishvili (2013) documents that the majority of emigrants from the village of Tianeti in Georgia are women. These numbers reflect long-term emigration and the picture among short-term migrants may be different; for example we know that although they are similar to long-term emigrants, seasonal migrants from Armenia are predominantly male (Liebensteiner 2014).

\footnotetext{
${ }^{14}$ However, estimates vary sizably. For example, Cantarji and Mincu (2013) suggest that only about 35 percent of Moldovan individuals 15 years of age and older working or looking for work abroad are females.
} 
Figure 27. Female Share in the Total Number of Long-Term Emigrants

Female Share in the Total Number of Long-Term Emigrants

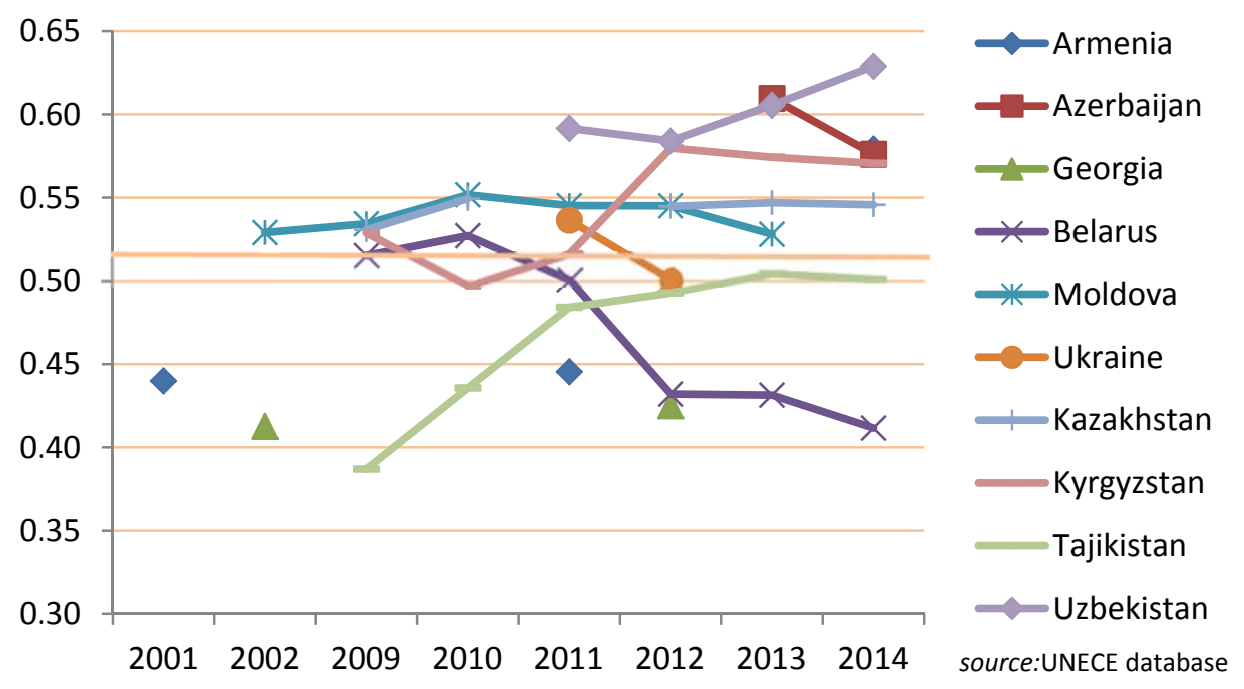

Migration destinations from these six countries are not limited to the former Soviet space (Brunarska et al. 2014). Nevertheless, the evidence from the South Caucasus suggests that Russia is the most common destination, especially for the less-educated individuals, and workers with higher education are more likely to emigrate to higher-income OECD countries (Dermendzhieva 2011). Danzer and Dietz (2014) also find that the more educated migrants move to EU countries. As of 2000, the emigration rate of the tertiary educated was the highest in Armenia (at 9 percent), followed by the Western CIS countries, its South Caucasian neighbors, and Central Asian countries (figure 28). 


\section{Figure 28. Emigration Rate of the Tertiary Educated}

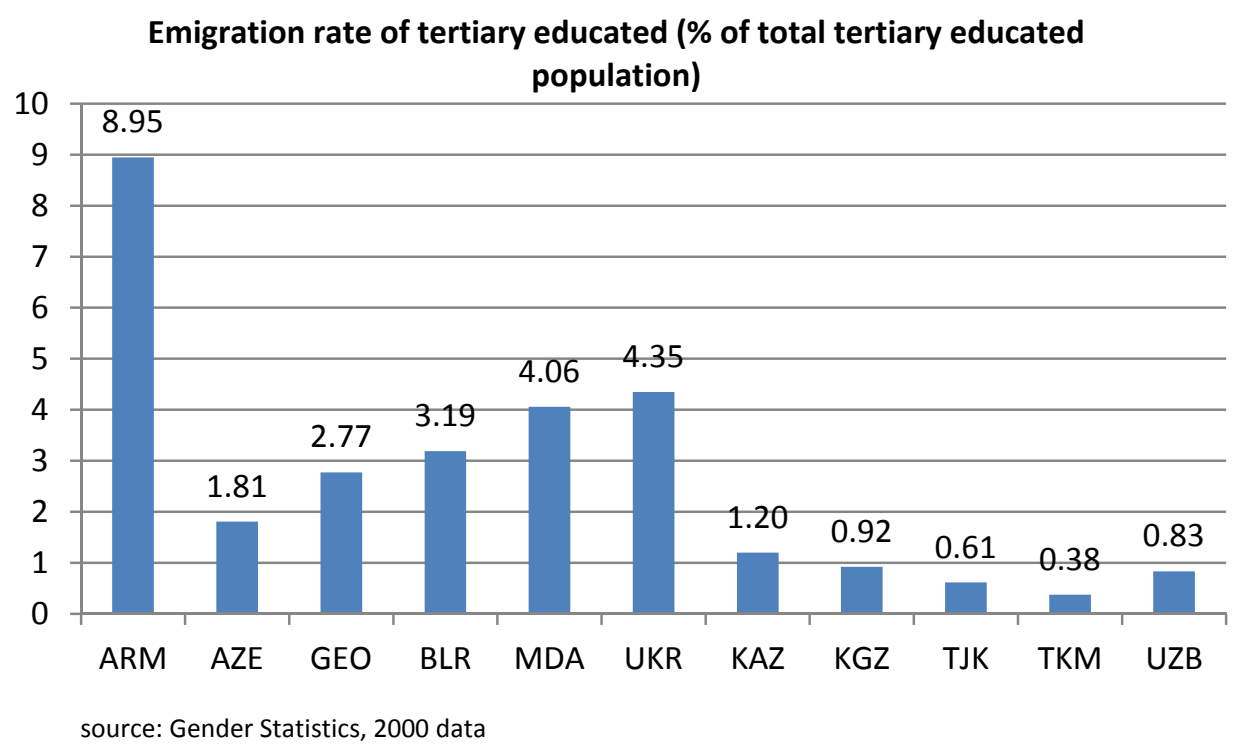

The nature of migration and the characteristics of migrants also vary. Ukrainian migrants in Italy are more likely to be female and older and seek temporary migration. On the other hand, Moldovan migrants in Italy are more likely to be young, male, and permanent (Marchetti et al. 2014). In the case of Spain, the migrants are mostly Ukrainians, followed by Moldovans, Armenians, and Georgians. Their employment rates are comparable to the natives, and, consistent with other studies, they are mostly educated (Farre and Rodriguez-Planas 2014). In the case of seasonal migration of Armenians, the primarily male migrants go to closer countries (e.g., Russia) and work in low-skill occupations, such as construction (Liebensteiner 2014).

In the case of Armenia, men's migration has a diverse effect on the lives of wives. Wives take on additional responsibilities, but the power dynamics and women's status do not appear to have changed. Therefore, arguably gender inequalities (male breadwinners and females subordinate in the household) have been reinforced (Menjivar and Agadjanian 2007). On the other hand, the impact on the elderly due to migration appears to be positive in Moldova (Bohme et al. 2015). Moreover, siblings are more likely to stay back to provide care for the elderly, as has been found in Moldova (Stohr 2015). Importantly, migration has played a positive role in child growth in Tajikistan by improving the nutritional intake of households (Azzari and Zezza 2011). 
Dermendzhieva (2011) finds that migration has raised local incomes and demand and, in the case of Armenia, increased the likelihood of running a family business. In the case of Moldova, Blouchoutzim and Nikas (2014) find a positive relationship between the remittances and consumption. Also for Moldova, Bouton et al. (2011) find that local wages increase in response to emigration, although the rate of increase varies by sector. On the other hand, Buckley and Hofmann (2012) find that in Tajikistan households that receive remittances are not better off or more entrepreneurial than households that do not receive remittances. Brown et al. (2013) suggest that in Azerbaijan remittances are negatively associated with financial deepening and are found to "deter bank intermediation and use of formal banking services." The ambiguity in the evidence on the impact of remittances on economic development and household well-being reflects the complexity of this relationship. For example, a number of studies find having a migrant household member lowers the likelihood of labor force participation of the remaining household members (Justino and Shemyakina 2012). However, Görlich et al. (2007) indicate that such increase in inactivity may be due to the remaining household members having to bear greater household production responsibilities and due to the young adults in such households obtaining higher education. At the same time, although having a migrant member appears to decrease crop income in agricultural households, Atamanov and Van den Berg (2012) suggest that in Kyrgyzstan this is the case only for permanent migrants and that further remittances partially compensate for this decrease, especially for smaller farms.

In contrast to international migration, internal migration in the region is relatively low (Sattar 2012). During 1990-2010 women were more likely to move internally than men and they did so for reasons that differed from men's. For example, until recently in Ukraine proportionately more internal female migrants moved to urban centers to study in higher education institutions whereas for men the dominant reason was employment opportunities (Sattar 2012). The ongoing military conflict has changed these dynamics and added another complicated dimension to the challenge of gainful job creation. 


\section{HEALTH}

In the immediate aftermath of the collapse of the Soviet Union, health outcomes deteriorated as a consequence of dramatic social and economic changes coupled with the decline in the provisioning of healthcare and social assistance. By many accounts, men's health outcomes worsened more than women's. Men's life expectancy initially declined more drastically than women's and hasn't recovered as much as women's life expectancy in all countries but Azerbaijan and Georgia (figure 29). In Belarus it has only recently surpassed its pre-transition level, whereas in Ukraine it remains below the pre-transition level.

\section{Figure 29. 1988-2013 Difference between Life Expectancies, by Gender}

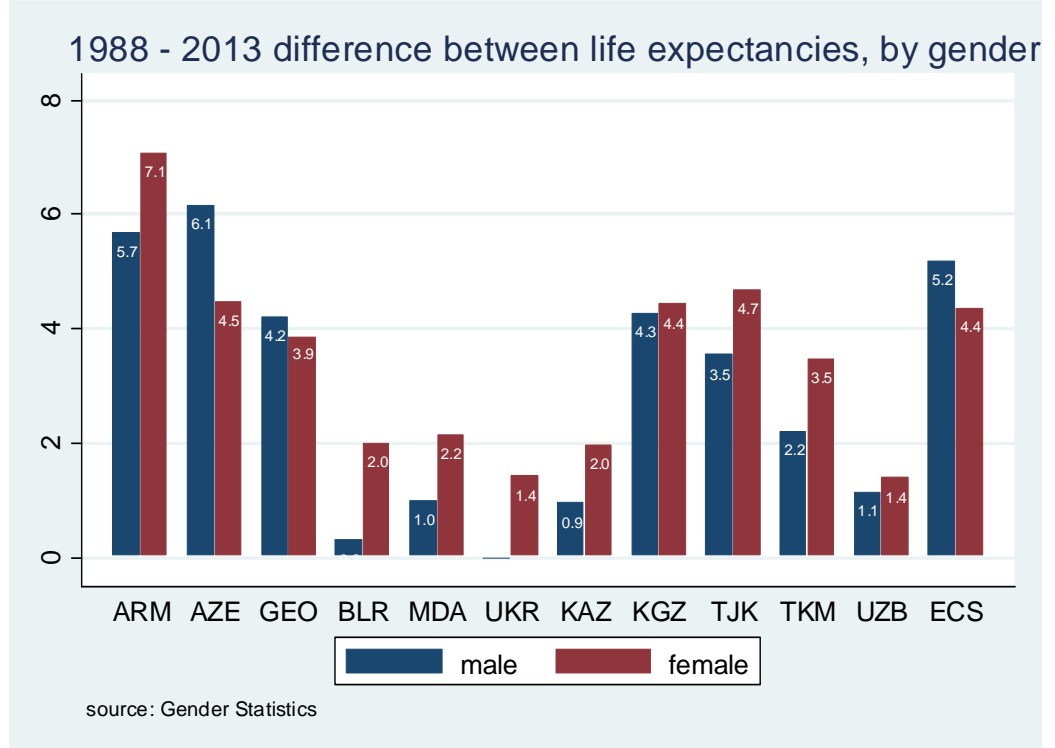

As a result, the gender gap in life expectancy widened compared to the pre-transition period and remains above the average gap for Europe and Central Asia in most countries of the region. It is especially large in Belarus and Ukraine, where, as we have discussed, men's life expectancy has barely reached the pre-transition levels (figure 30). However, the life expectancy of not only men but also women is below the average for Europe and Central Asia, especially for men in Central Asia and Western CIS (figure 31). Even so, these estimates may be overestimated due to the undercounting of infant mortality and failing to account for the migration in population estimates (Rechel et al. 2013; Badurashvili et al. 2001). 
Figure 30. Gap in Life Expectancy at Birth

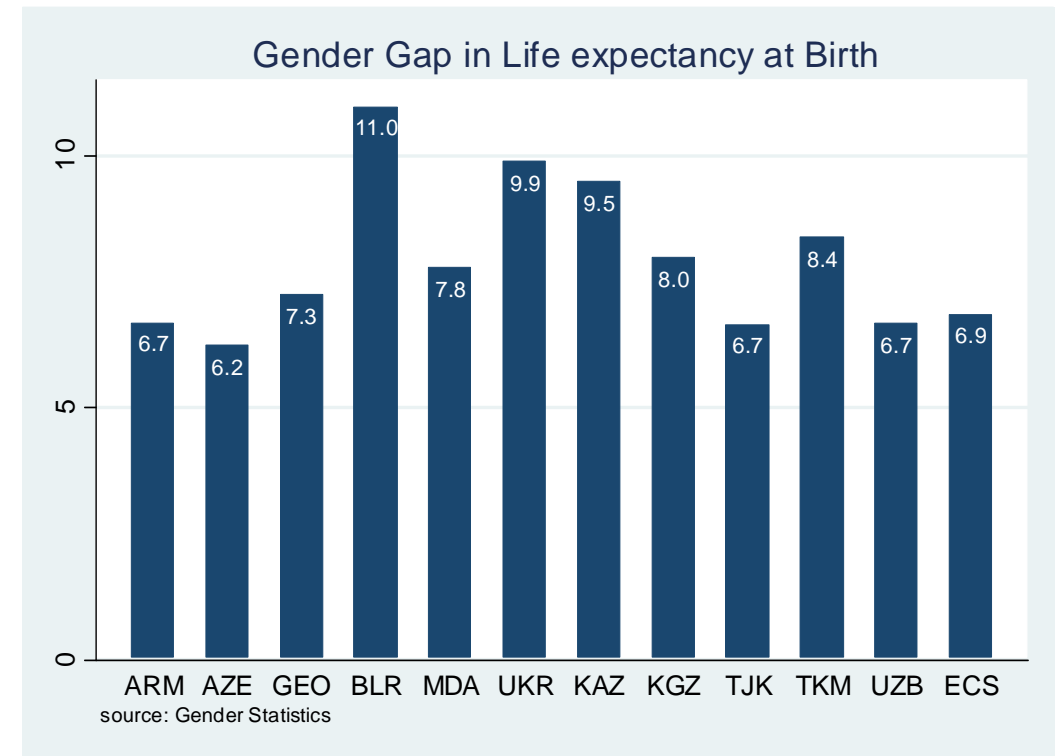

Figure 31. Life Expectancy at Birth, by Gender

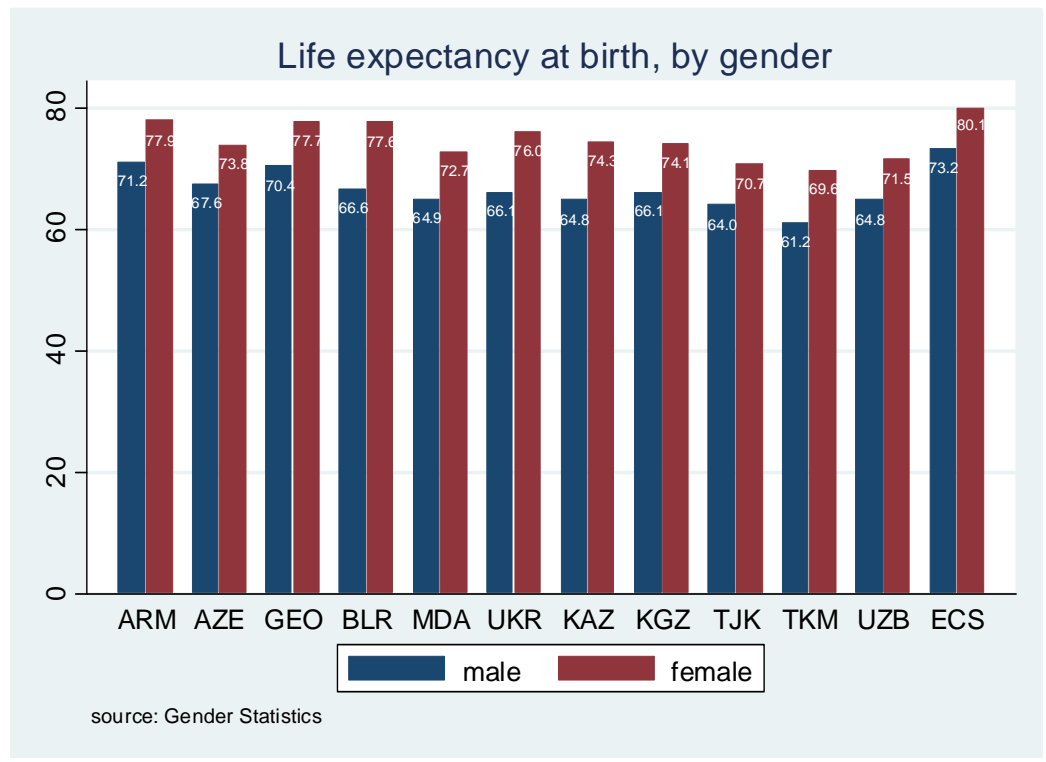

In all countries, proportionately more men than women die of communicable diseases and injuries. In Belarus, the proportions of death due to injury for both men and women are wellabove the ECA average (figure 33). In Ukraine, there was an increase in the proportion of deaths due to communicable diseases between 2000 and 2012, accompanied by a halving of the proportion of death due to injury for women and a more than 10 percentage points decrease for 
men. In contrast, in Tajikistan, we observe a sizable decrease in the female death rate due to communicable diseases accompanied by an increase in the female death rate due to noncommunicable diseases.

Figure 32. Death Rate (per 1,000)

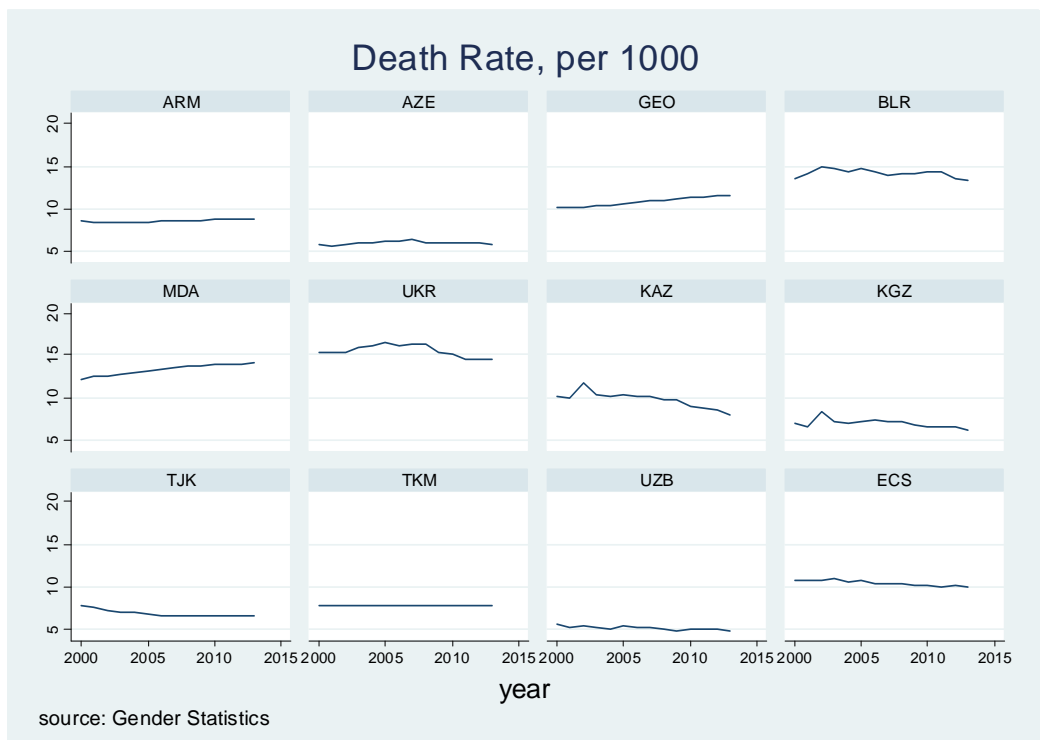

Figure 33. Causes of Death, by Gender
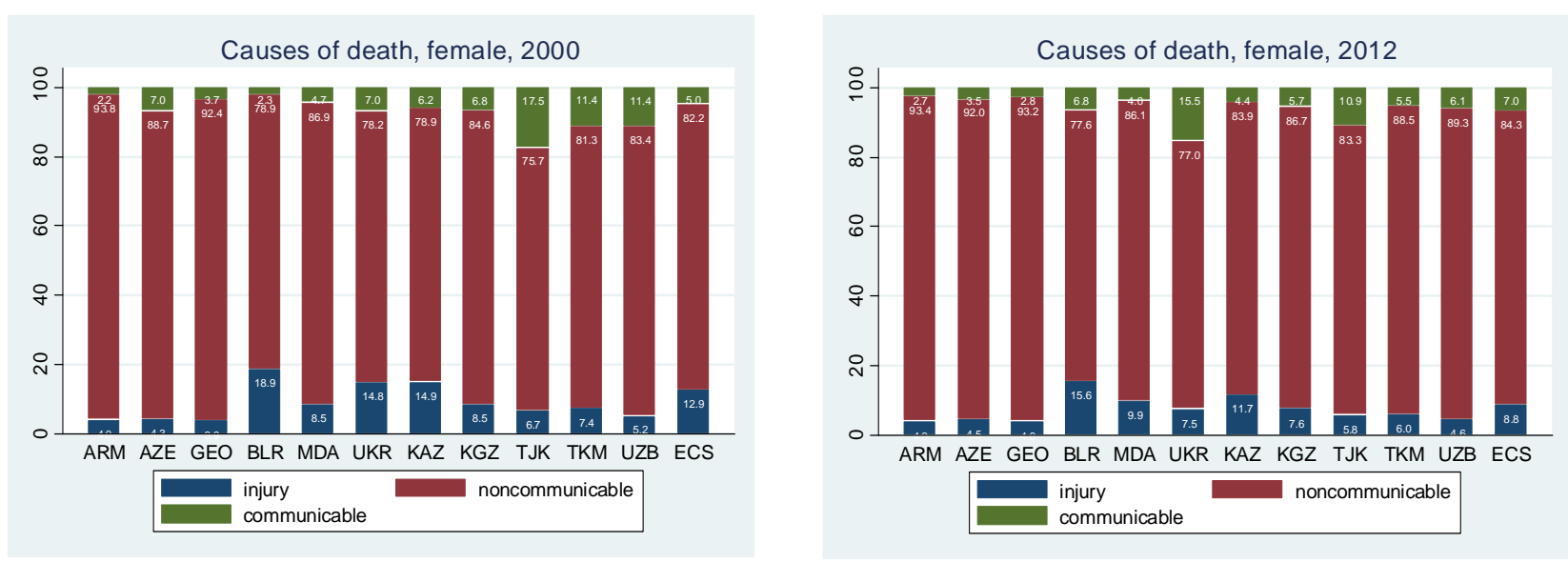

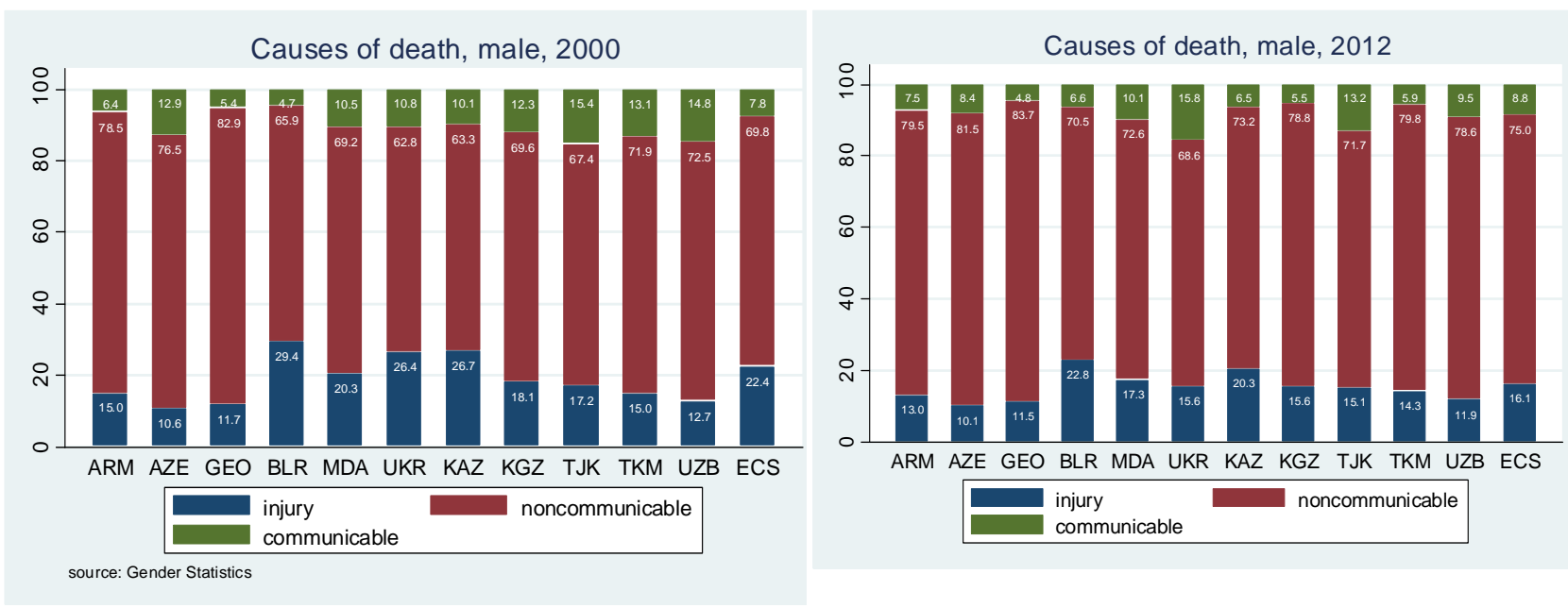

By many accounts, the worsening of men's health outcomes since the beginning of transition has been attributed to the increases in their alcohol consumption, which leads to alcohol poisoning, pneumonia, suicides, injuries, and cardiovascular diseases (Rechel et al. 2013; Cockerham et al. 2006). This was the case especially in Belarus and Ukraine, but also to some degree in Central Asia (Cockerham et al. 2004). Higher suicide rates, for example, have been one consequence of alcohol consumption. In Belarus, alcohol consumption has contributed to men being five times as likely to commit suicide as women (Paravaya 2012). ${ }^{15}$ This is the case because of the higher rate of alcohol consumption among men and because consuming alcohol raises men's odds of committing suicide more than women's (Razvodovsky 2011). Alarmingly, whereas suicide rates in urban areas in Belarus contracted, in rural areas they increased between 1995 and 2005 and are particularly high among rural men, potentially due to the greater social isolation and the lack of medical services in rural areas (Razvodovsky and Stickley 2009). Further contributing to men's poorer outcomes is the finding that men tend to underutilize primary health services compared to women. For example, survey results from Kazakhstan and Uzbekistan show that only 17.6 percent of primary care patients were men, 47 percent were women, and the remaining 35 percent were children (Cashin et al. 2002))

\footnotetext{
${ }^{15}$ In 2005, in Belarus the suicide rate was 53.81 per 100,000 for men and 7.82 per 100,000 for women, compared to the OECD averages of 18.4 and 5.6 (Razvodovsky and Stickley 2009; OECD 2009).
} 
Although men's substance-use issues have received the most attention in the literature, the incidence of alcohol and substance use among women in the region also increased and, according to some estimates, women comprise about 20 percent of the substance-using population among former Soviet Union and Latin American countries (Global Illicit Drug Trends 2002). However, the proportion of females in the substance-using population seeking treatment varies from only 2 percent in Georgia to 10.5 percent in Kyrgyzstan (Otiashvili et al. 2013; European Monitoring Centre for Drugs and Drug Addiction 2015). Such low proportions can be attributed to financial constraints, the lack of services targeted at women, and a strong social stigma attached to female substance abuse in particular (Otiashvili et al. 2013). As a result, the excess mortality rates among substance-using females are higher than among substance-using males.

One indicator directly related to female health is the maternal mortality ratio. It increased immediately following the collapse of the Soviet Union in many countries of the region due to the decline in the financing and availability of maternal health services (Falkingham 2003). Even though the ratio has contracted since then, the official maternal mortality ratios in the region are above the average for Europe and Central Asia (ECA) in all countries except Belarus, and are especially high in the Central Asia countries, followed by the countries of the South Caucasus (figures 35 and 36). In fact, the reported maternal mortality ratio in Kyrgyzstan is 75 women per 100,000 live births, which is more than four times the ECA average. One part of the explanation is the continued decline in maternity care use, as Meurs and Giddings (2012) find for Tajikistan. The low healthcare expenditures compared to the ECA average is another reason (figure 34). In addition, the low maternity care knowledge of the population and care providers may be another potential contributing factor. For example, in Kyrgyzstan and Tajikistan, which demonstrate particularly high maternal mortality ratios, healthcare providers correctly answered only half the questions on a knowledge questionnaire about maternity care (Wiegers et al. 2010). 
Figure 34. Health Expenditures per Capita

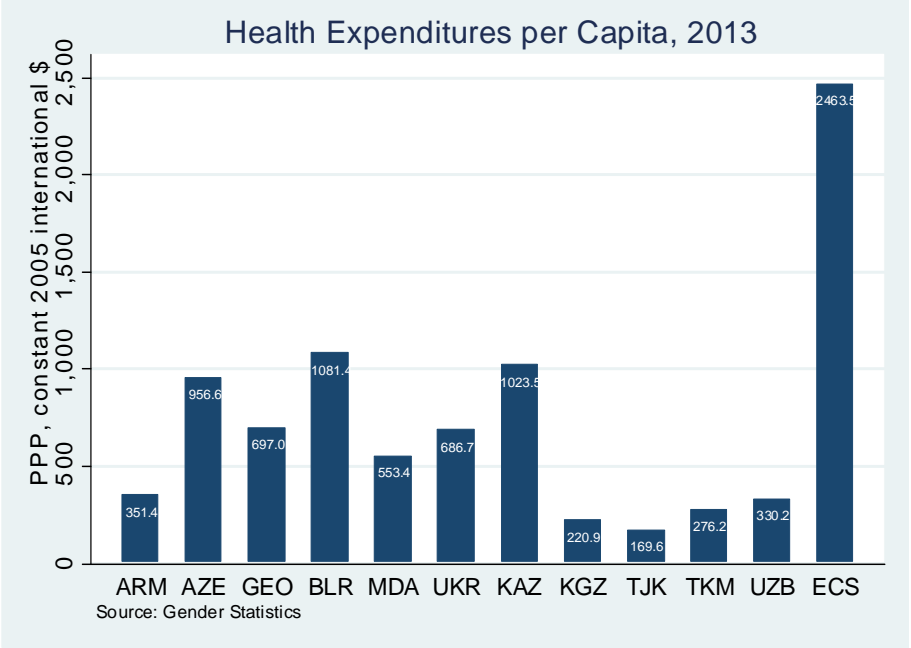

Figure 35. Trends in Maternal Mortality Ratio

Maternal mortality ratio, per 100,000 live births

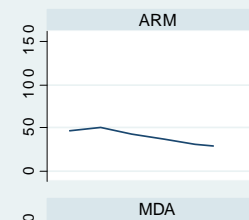

AZE

GEO

BLR
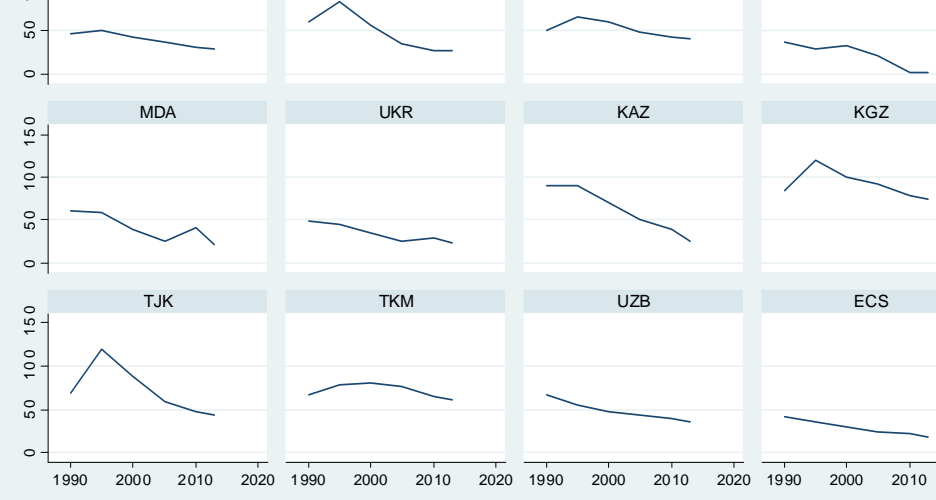

TKM
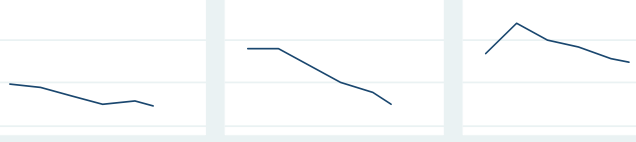

UZB

ECS

source: Gender Statistics

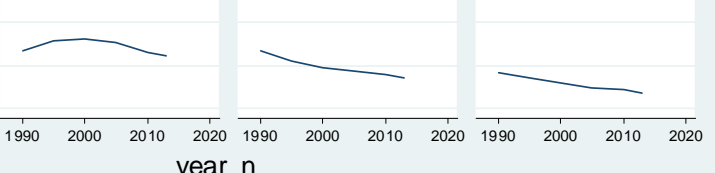
year_n 


\section{Figure 36. Maternal Mortality Ratio}

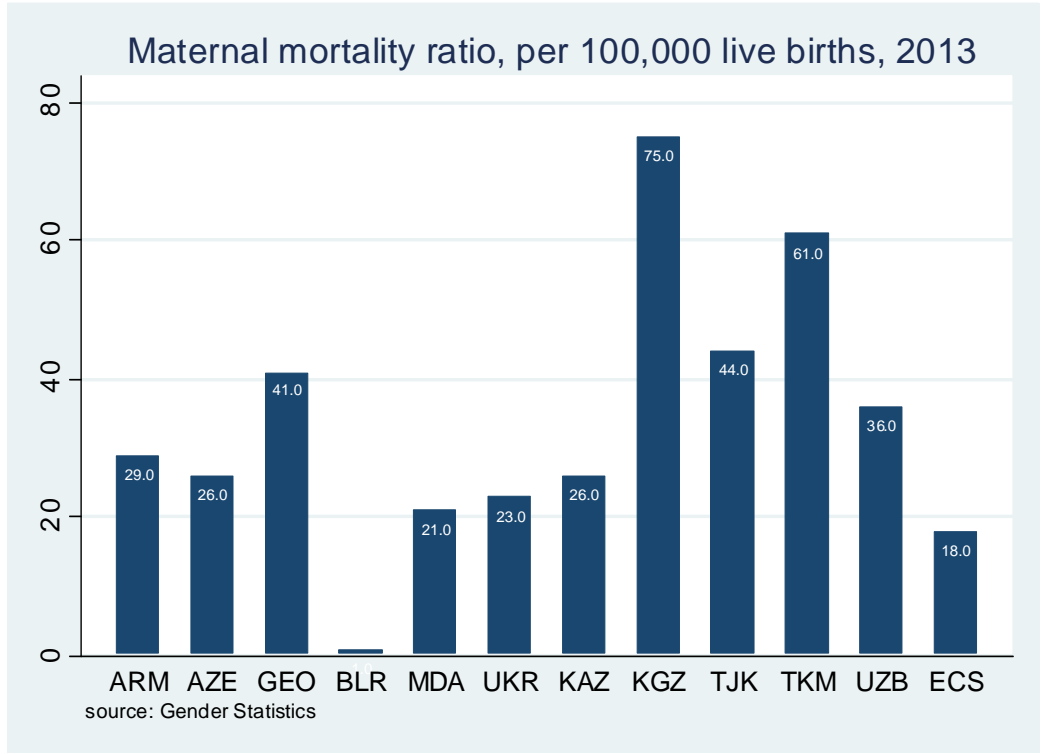

An especially striking development in the South Caucasus has been a spike in the male births per female birth that occurred during the 1990s (figure 37). Despite the slight reduction over the last decade, the sex ratio in these countries remains high, with more than 110 male births for every 100 female births. High sex ratios are also present in the Caucasus region of the Russian Federation and in the Balkan region, e.g., Montenegro and Albania (Guilmoto 2009; Duthé et al. 2012). ${ }^{16}$ This picture reflects a strong preference for having sons, combined with the availability of ultrasound technology and access to abortion in the environment of declining fertility. Duthé et al. (2012) demonstrate the strong preference for sons in the South Caucasus through their analysis of fertility intentions and behavior and establish that, similar to other countries, the sex ratios at birth are especially high among third births. Moreover, the sex ratios in the South Caucasus appear to follow a pattern similar to other countries, in which the ratio initially increases among the urban well-off individuals and is then followed by the poor or rural dwellers (Guilmoto 2009).

\footnotetext{
${ }^{16}$ Similar increases in the sex ratio followed by leveling off or reductions took place in a number of Asian countries (Guilmoto 2009).
} 


\section{Figure 37. Trends in Sex Ratio}

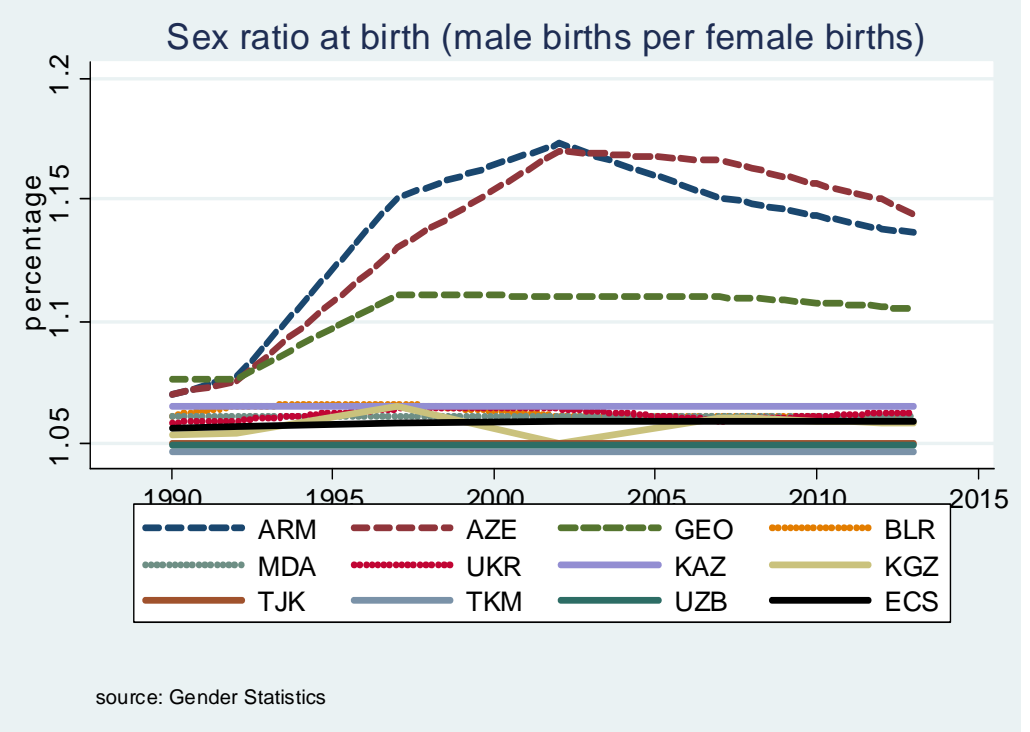

\section{POLITICAL REPRESENTATION}

Despite measures taken to eradicate gender discrimination at the policy level in the region, women are underrepresented in the political sphere. The share of females in ministerial positions is below the average for Europe and Central Asia (ECA) for all countries of the region (figure 38). Moreover, with the exception of Belarus, the proportion of women in the parliament, too, is below the ECA average. It is noteworthy that the females' share in parliament in Central Asian countries is above the shares in the South Caucasus and Ukraine. 


\section{Figure 38. Proportion of Women at Different Levels of Decision-making}

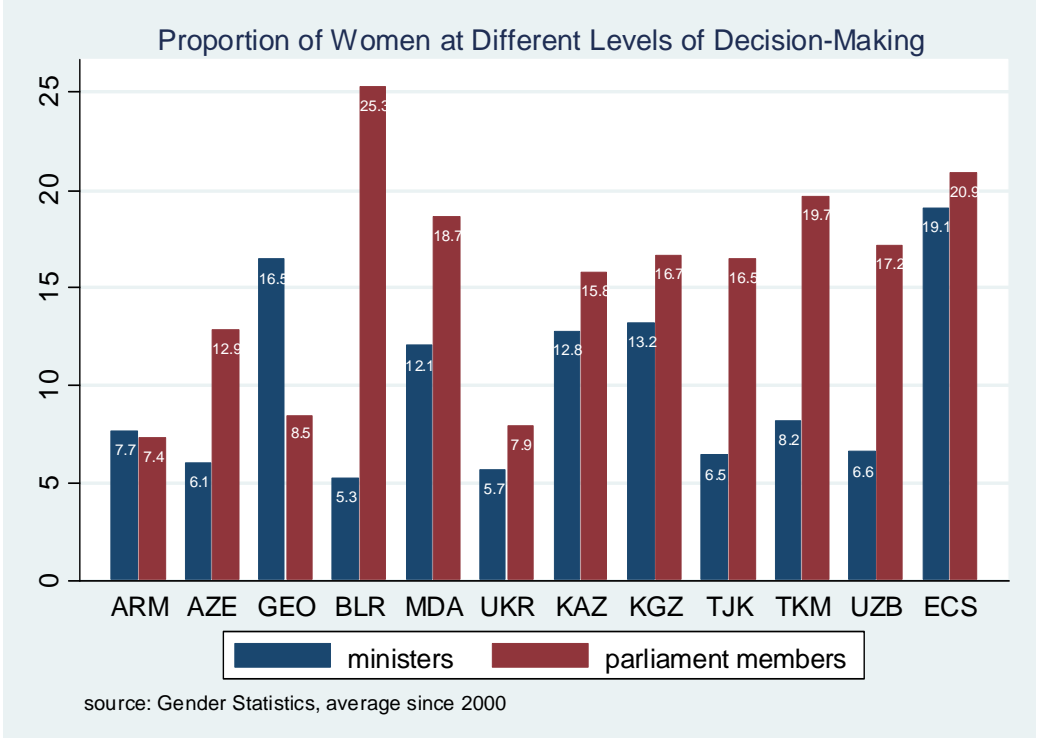

In their analysis of female representation in politics in Asian countries (including Armenia, Azerbaijan, Georgia, and Uzbekistan), Joshi and Och (2014) argue for the need to recognize that women (or men) are not a homogeneous group and that higher female representation in political life may not necessarily go hand in hand with the representation of different segments of the population. They find, for example, that none of the female members of parliament in the region represent housewives and agricultural workers,${ }^{17}$ which are a considerable portion of women in these countries. The most common professions of women in parliament are either "talking" or specialized professions. ${ }^{18}$ For example, in Uzbekistan, 100 percent of female parliamentary members are either in "talking" or specialized professions, whereas in Georgia this number is 67 percent being civil servants. This occupational breakdown appears to mirror the occupational composition of females in wage employment. In addition, all female members of parliament in Georgia and Uzbekistan possess a university degree and are, on average, younger than their male counterparts. Hence, on the one hand, the composition of female parliament members by occupation, education, and age may not reflect the female population. However, Joshi and Och

\footnotetext{
${ }^{17}$ In the study, agricultural workers are classified as the "working class" category (Joshi and Och 2014).

18 "Talking" professionals are teachers, journalists, filmmakers, religious clergy, entertainers, lawyers, and professors. Specialized professionals are doctors, nurses, architects, scientists, engineers, and economists (Joshi and Och 2014).
} 
(2014) also posit that this may be a reflection of a trade-off between expertise and representativeness.

\section{SOCIAL NORMS AND CULTURAL ATTITUDES}

Underlying the gender inequalities in social, economic, and political realms is the question of what can be done to reduce them and whether the reduction in these inequalities is viewed as a priority by policymakers and the general public. Attitudes towards gender roles in the society can substantially influence and reinforce gender inequalities in society and hinder or facilitate the

implementation of policies aimed at reducing them. However, there is disagreement on the extent of policymakers' emphasis on changing these norms (World Bank 2013).

The countries of the region vary in their gender norms and in their attitudes towards female engagement in the economic, political, and household spheres. Both men and women in Central Asian and South Caucasus countries tend to hold more conservative views than their counterparts in Central Asian countries; however, there are notable gender differences in their views. For example, in Ukraine only 41 percent of women agree with the statement that men make better political leaders than women, compared to 66 percent of men (figure 39). 
Figure 39. Percentage that Agree that on the Whole, Men Make Better Political Leaders than Women ${ }^{19}$

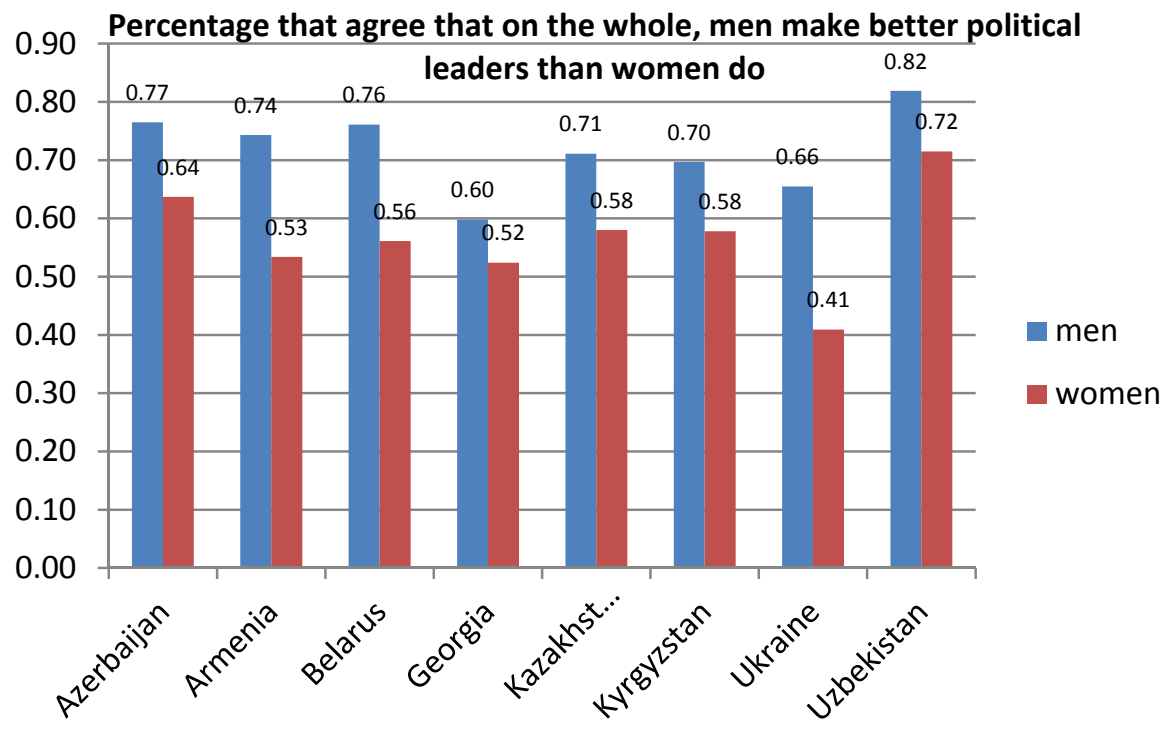

The gender variation is more pronounced in terms of women's engagement in labor markets. For example, proportionately fewer women agree that, when jobs are scarce, men should have more right to a job than women. Even so, in the case of Azerbaijan, the smaller percentage corresponds to 73 percent of women, compared to 16 percent of women in Belarus or 23 percent of women in Ukraine (figure 40).

\footnotetext{
${ }^{19}$ Figures based on the World Values Survey data.
} 
Figure 40. When Jobs Are Scarce, Men Should Have More Right to a Job than Women

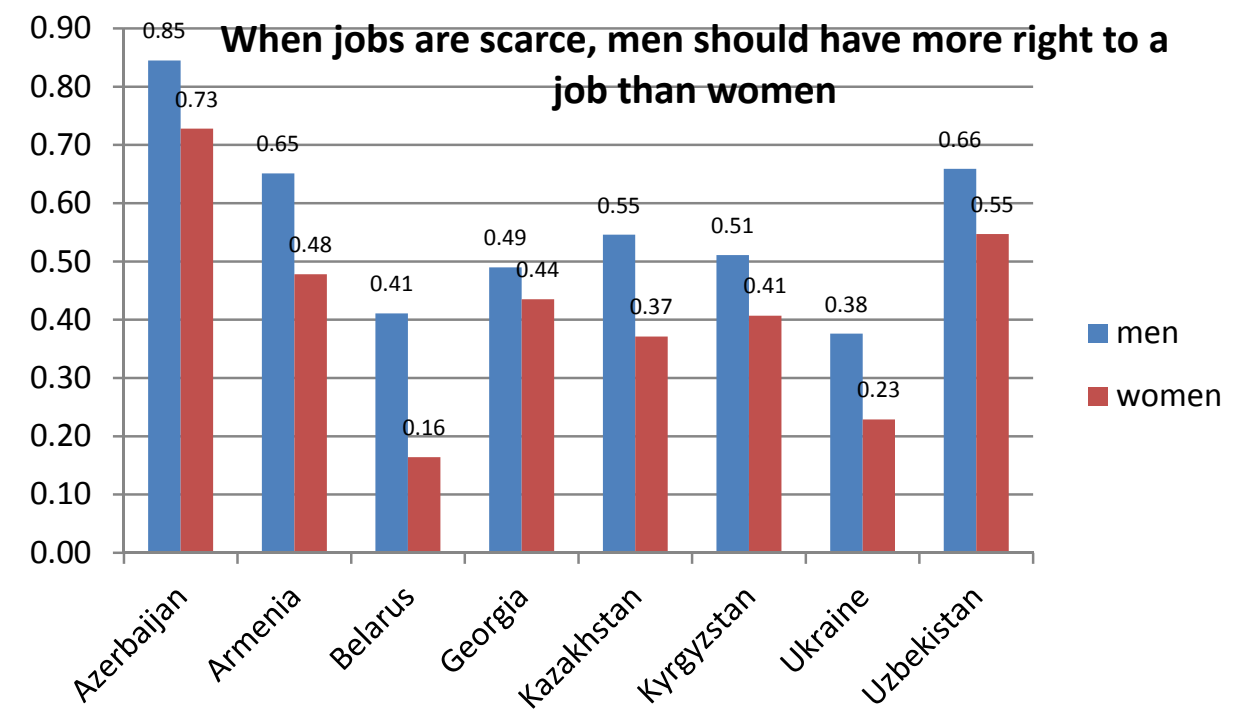

If woman does hold a job and earns more than her husband, this is likely to cause problems in the view of 63 percent of men and 58 percent of women in Uzbekistan (figure 41). With the exception of Georgia and Kazakhstan, proportionately more men tend to hold this view than women.

Figure 41. If a Woman Earns More Money than Her Husband, It's Almost Certain to Cause Problems

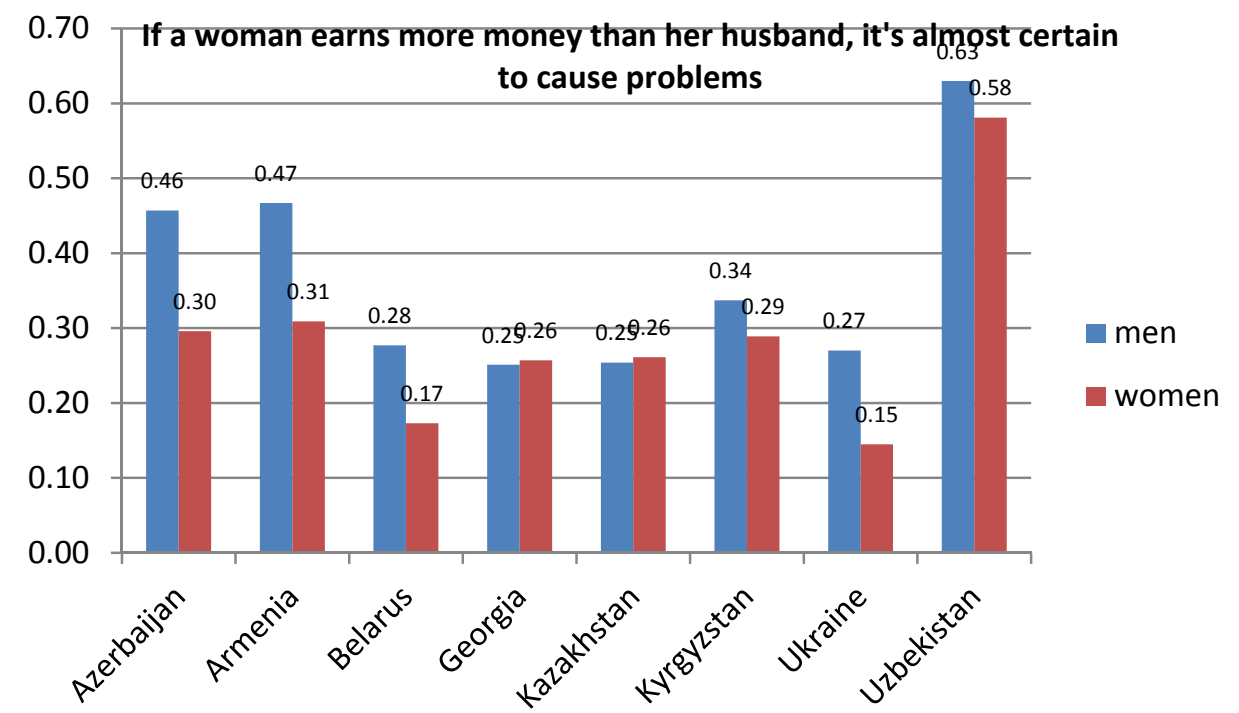


At the same time, proportionately more women believe that having a job is the best way for a woman to be independent (figure 42). This number for females varies from 35 percent in Azerbaijan to 73 percent in Georgia. Notably, the gender difference is the greatest in Georgia as well, as only 55 percent of Georgian men believe that having a job is the best way for a woman to be independent.

Figure 42. Having a Job Is the Best Way for a Woman to Be an Independent Person

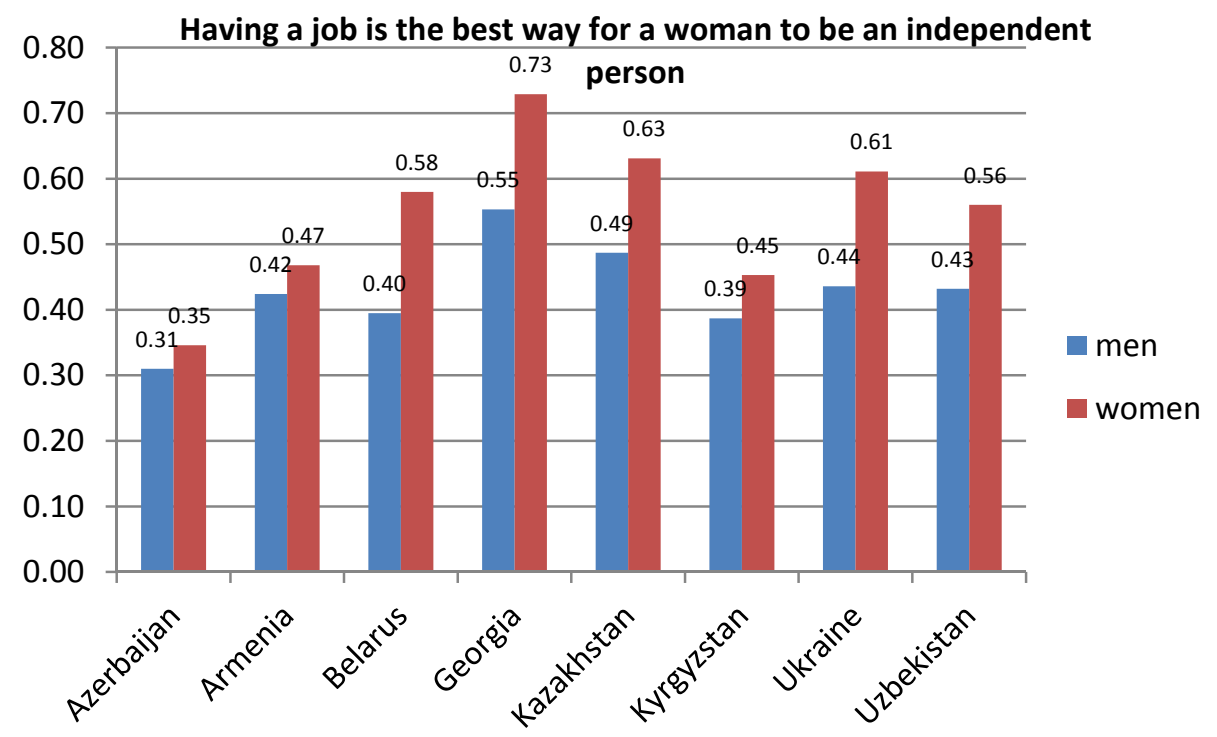

In all countries of the region, proportionately more men perceive themselves to be better business executives than women; less than half of women in Belarus, Georgia, Kazakhstan, Kyrgyzstan, and Ukraine consider men to be better business executives (figure 43). 
Figure 43. On the Whole, Men Make Better Business Executives than Women

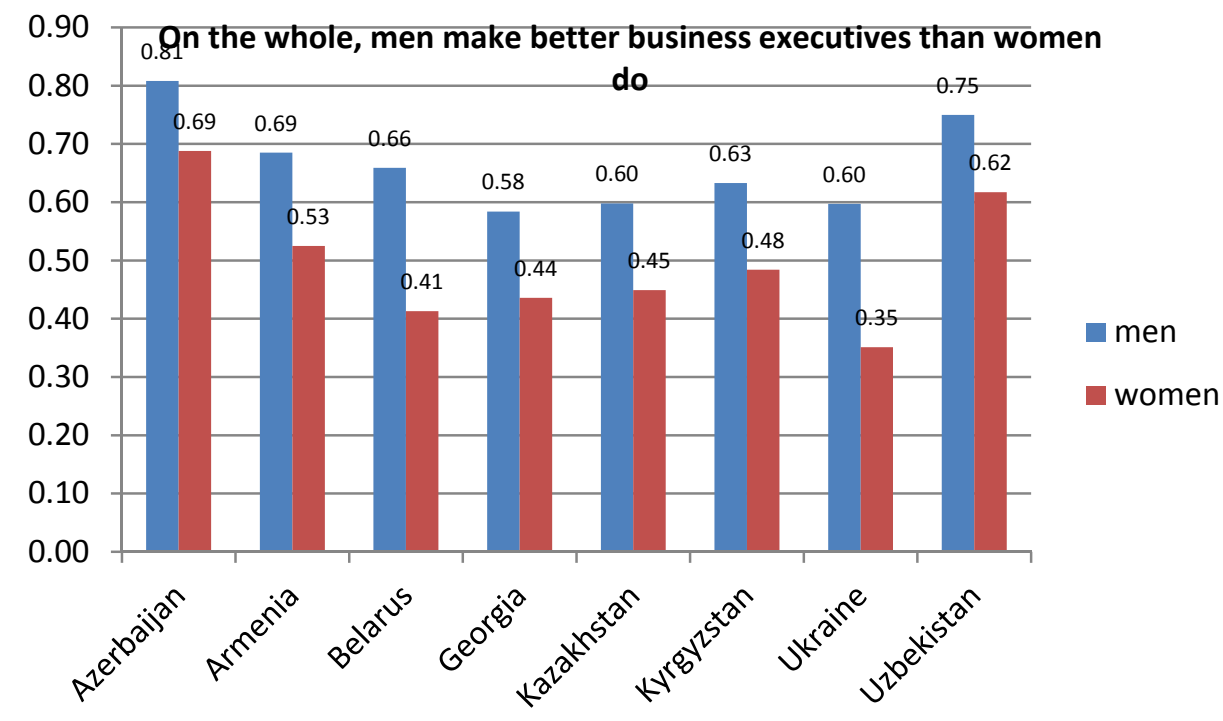

When it comes to education, proportionately more men believe that a university education is more important for a boy than for a girl. Notably, in Ukraine almost half of men believe that to be the case (figure 44).

Figure 44. A University Education Is More Important for a Boy than for a Girl

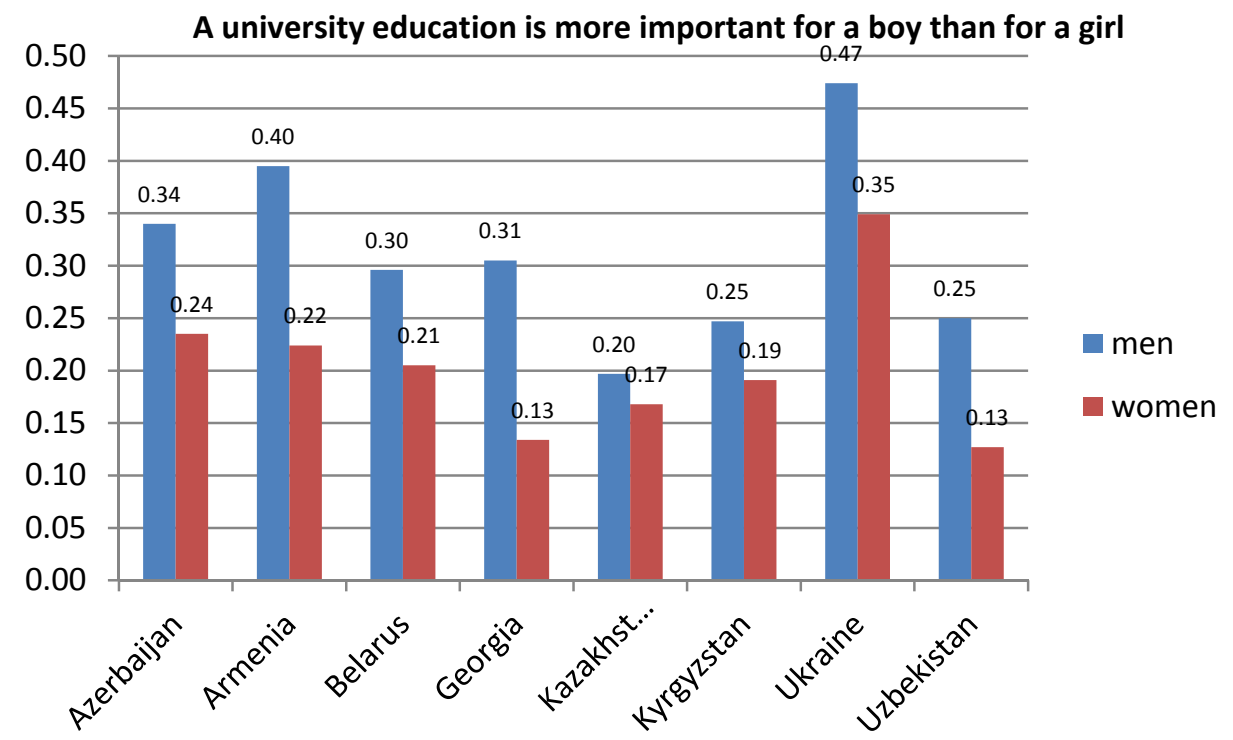


With respect to child rearing, the countries of the South Caucasus stand out in that close to half of both men and women consider that children suffer when a mother works for pay (figure 45). In fact in Georgia proportionately more women hold this view than men. These views may play an important role in the effectiveness of social care support policies at raising the female wage employment and entrepreneurship in the South Caucasus. We note that such views are much less common in Central Asia and in the Western CIS.

Figure 45. When a Mother Works for Pay, the Children Suffer

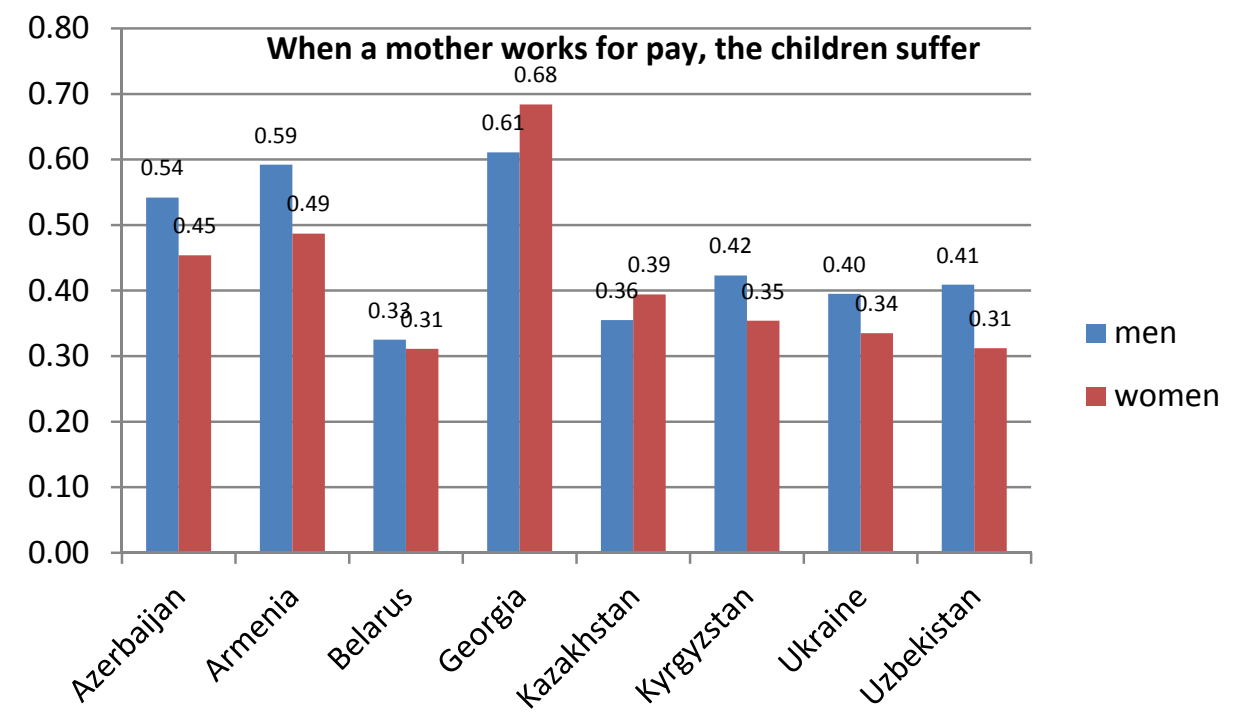

At the same time, the view that being a housewife is as fulfilling as working for pay is much more prevalent in Central Asia and Western CIS than in South Caucasus (figure 46), which suggests that women and men in the South Caucasus appear to view their commitment to childrearing as a choice made due to the belief that a child would suffer if a mother were to work. 
Figure 46. Being a Housewife Is Just as Fulfilling as Working for Pay

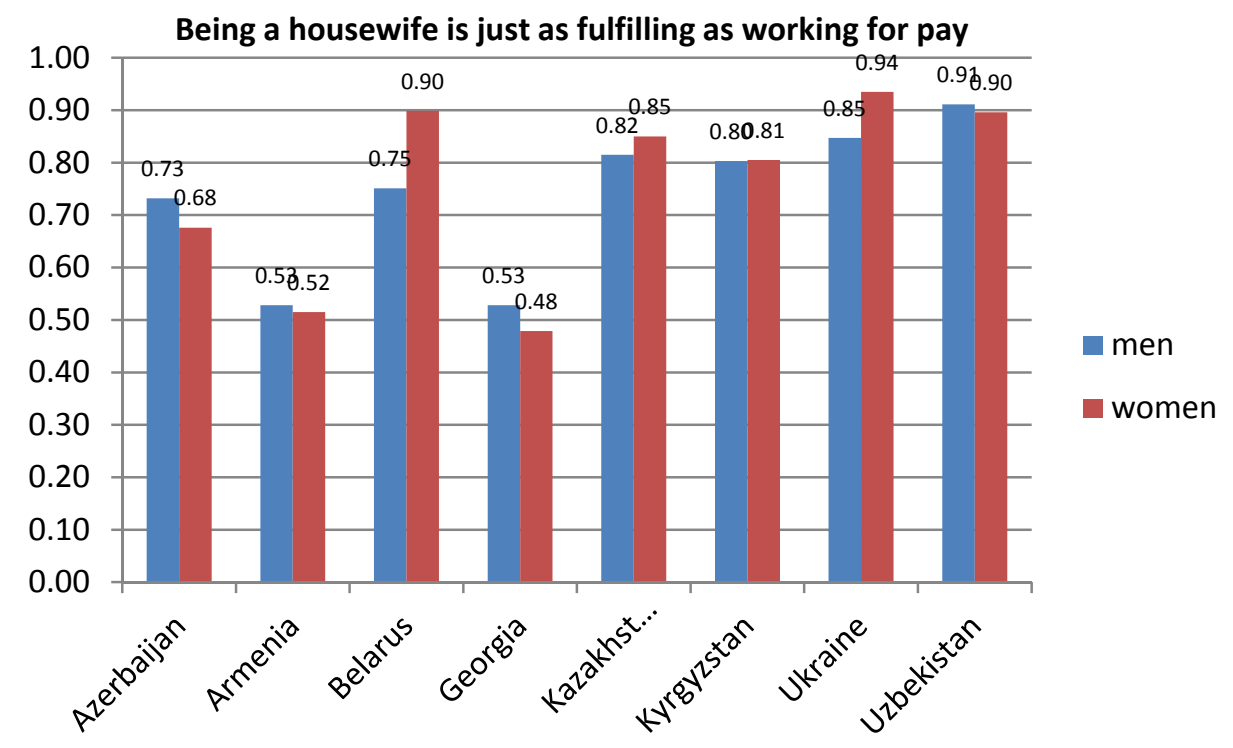

One of the notable developments following the collapse of the Soviet Union was the resurgence of traditional norms and practices, especially in the South Caucasus and Central Asia. However, recent evidence indicates the leveling off. For example, Nedoluzhko and Agadjanian (2015) examine traditional marital practices, such as bride kidnapping, in the Kyrgyz Republic and find that their incidence declined. The cultural attitudes towards abusive behavior against women also appear to be changing. For example, the proportion of individuals who feel that husbands are justified in beating their wives has declined in the countries for which the time series data are available. Nevertheless, we observe a large variation, with the percentage of women who hold this view varying from 4.1 percent in Belarus to 59.6 percent in Tajikistan (figure 47). Income appears to play a role in the level of acceptable of wife beating within the countries. In their analysis of Asian countries, which includes Armenia and Kazakhstan, Rani and Bonu (2009) find that household wealth and education were negatively associated with the acceptance of wife beating. Furthermore, in Armenia, women who contributed more than 50 percent of total household expenditures were less likely to tolerate wife beating as an acceptable practice, although only 1.9 percent of females in the sample belonged to this category (Rani and Bonu 2009). In Belarus the percentage of women who think it is acceptable for a husband to beat his wife for any reason is 4.1 percent on average, but it is 9.8 percent in the poorest wealth quintile, as opposed to 1.2 percent in the richest. Moreover, 10.2 percent of women with general basic 
education report that the beating is acceptable for any of the above reasons as opposed to 1.8 percent of women with tertiary education (National Statistical Committee of the Republic of Belarus 2013). Similar patterns are observed in Azerbaijan, Moldova, Georgia, Kyrgyzstan, Tajikistan, Turkmenistan, and Ukraine.

Figure 47. Changes in Social Norms

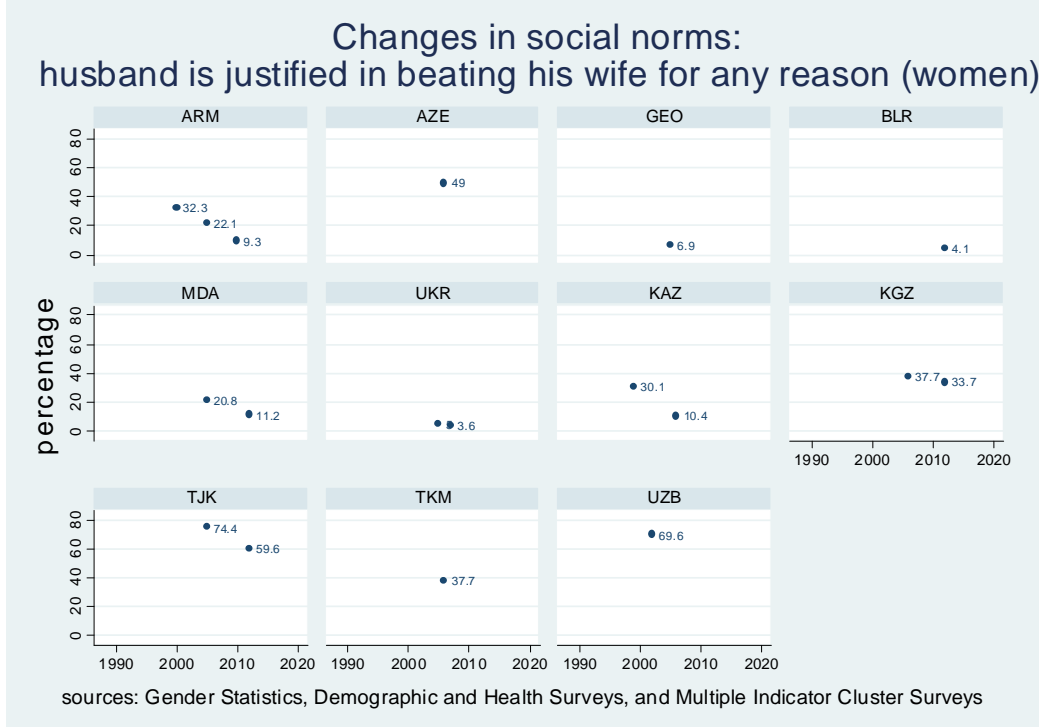

Moreover, there is a negative relationship between the GNI per capita and the proportion of women who think that a husband is justified in beating his wife (figure 48). 


\section{Figure 48. Social Norms and GNI per capita}

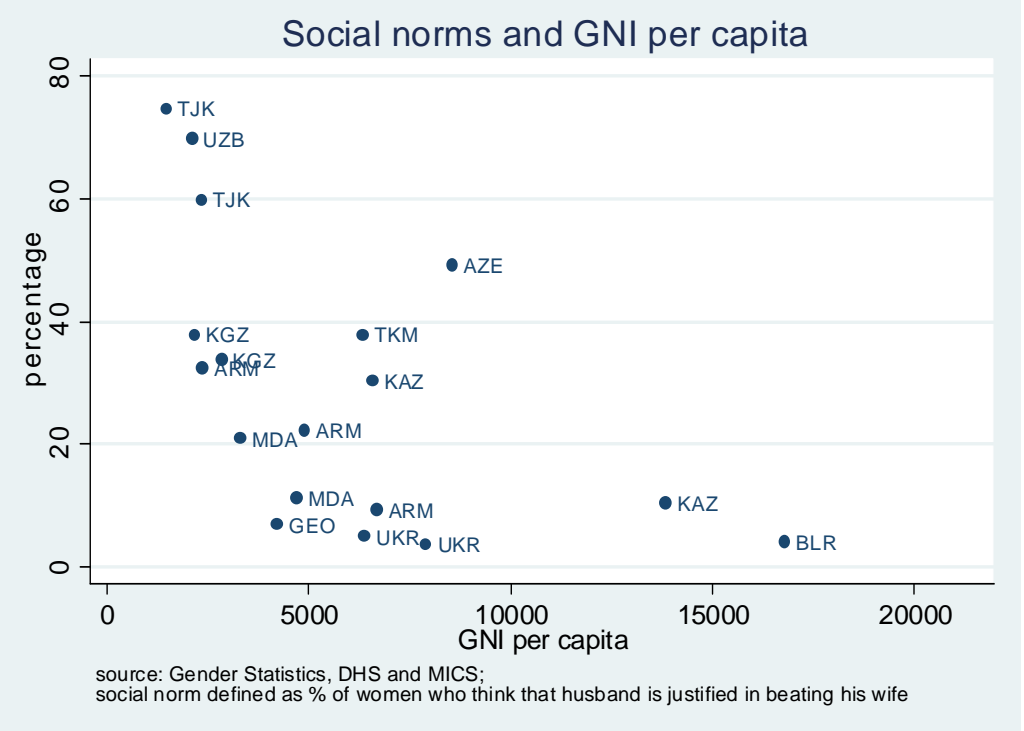

This evidence appears to suggest that at least some of the differences in gender norms are related to measures of economic well-being. Nevertheless, Rani and Bonu (2009) emphasize that gender norms are pervasive and that education and economic growth are not sufficient to explain country-level variation in gender norms.

\section{REGULATORY SYSTEM}

Creating a gender-equal legal framework is an important pre-condition for addressing gender inequities in employment and entrepreneurship. Out of the 11 countries in the region, only Armenia has no legal differences between women and men in any of the areas reported in the World Bank's Women, Business, and the Law 2016 report (World Bank 2015). Countries of the region have "the world's most extensive job restrictions on women, keeping women out of many occupations" (World Bank 2015). Indeed, "women in Kazakhstan are prohibited from 299 jobs, while women in Belarus are prohibited from 182 jobs." Such restrictions contribute to the persistence of industrial segregation and gender wage gaps. However, the region has made progress on other dimensions. Indeed, the report finds that it has led the way in implementing legal and regulatory reforms addressing barriers for women's economic advancement, passing 
legislation providing protection to women experiencing domestic violence (Belarus), criminalizing marital rape (Georgia), strengthening parental benefits (Belarus, Georgia), and enacting childcare reforms (Tajikistan).

\section{SUMMARY AND POLICY RECOMMENDATIONS}

Gender disparities limit the prospects for robust, sustainable, and inclusive growth in the countries of Central Asia, South Caucasus, and Western CIS. In this paper, we found:

\section{Labor force participation, employment, and unemployment: Female labor force participation rates remain below men's rates. The labor force participation and employment rates for men and women have either remained stable or declined over the last two decades. However, these rates for females remain lower their male counterparts.}

Employment composition: Female employment is less secure. Women tend to be underrepresented as both wage earners and as employers. In the countries with high rates of selfemployment (e.g., Armenia, Georgia, and Azerbaijan), women are overrepresented in the category of contributing family workers.

\section{Wage gaps: Women earn as much as $\mathbf{7 8}$ percent (Ukraine) and as little as $\mathbf{5 0}$ percent} (Azerbaijan) as their male counterparts. Some of the wage gaps are due to industrial and occupational segregation and women working fewer hours than men. However, a large portion of the gap remains unexplained. While gender wage inequality has improved in most countries in the region, it has increased in Belarus, Tajikistan, Azerbaijan, and, more recently, in Tajikistan.

\section{Entrepreneurship: Female entrepreneurs face greater barriers in accessing credit and tend to have weaker networks in the region. Female businesses tend to be smaller than those of their male counterparts, even though female-owned businesses have greater scale economies and employ proportionately more women. Thus, encouraging female-owned business expansion can have a greater impact on overall growth and specifically on female employment.}


Agriculture: Women are less likely to be landowners than men. They typically own smaller plots of land compared to men and are more likely to be contributing family workers. Women tend to engage in the agricultural production aimed at own consumption, whereas men tend to engage in the production of cash crops, negatively affecting their earning capacity.

Time use: Gender disparities are present in both paid and unpaid work. Gender gaps in unpaid and paid work vary from moderate (Moldova) to high (Armenia and Azerbaijan). However, in total work time women spend more time working than men. Gender gaps in time use are particularly large in childcare and they tend to be higher in urban areas compared to rural areas.

Education: High degree of gender specialization by subject contributes to industrial segregation. There is relative gender parity in educational attainment at the primary and secondary levels. At the tertiary level female share in education is more than a half. However, there is substantial variation in the share of women by subject, underscoring the high degree of specialization that reinforces the industrial and occupational segregation by gender. Women's returns to education tend to be higher than men's.

Migration: Migration has important implications for the economic and demographic future of the region. Gendered patterns of migration vary widely. In most countries of the region, external migration appears to be a male phenomenon although there is considerable regional variation by gender within countries. Less-educated migrants move within the former Soviet space, whereas more-educated migrants are more likely to leave the region altogether. Internal migration is relatively low, with females moving to urban areas primarily to study and males migrating to cities to work.

\section{Reducing these gender inequalities has the potential to contribute to the process of inclusive growth and development in the countries of the South Caucasus and Western CIS and to the achievement of the Sustainable Development Goals of poverty and inequality reduction (Sattar 2012; Elborgh-Woytek et al. 2013; Woetzel et al. 2015). To achieve such reductions, a comprehensive, evidence-based strategy is needed that complements supply-side}


interventions with demand-side measures aimed at gainful employment creation (Kabeer 2012). Such strategy will include the following elements:

\section{Remove legal and regulatory barriers to women's economic empowerment.}

Although substantial progress has been made, pervasive gender-based occupational restrictions preventing women from engaging in employment and entrepreneurship remain in the region.

2. Implement policies to address women's care and domestic responsibilities to promote decent employment opportunities, as well as increase productivity and earnings. The role of women's care and domestic responsibilities in limiting women's engagement in labor markets as workers and as entrepreneurs has to be an integral part of a strategy to reduce gender inequality. Programs providing access to affordable and reliable childcare, childcare subsidies, and public childcare provisioning are an effective approach for improving women's labor market outcomes and earnings in developing and transition economies (Buvinić et al. 2013; İlkkaracan et al. 2015; Antonopoulos and Kim 2011).

3. Improve the productivity of agriculture and rural economy. A large proportion of the workforce in most countries of the region is employed in agriculture and in rural areas. Women in rural areas are proportionately more likely to be contributing family workers. Improving the productivity of agriculture will be a key to changing the gender gaps in employment composition in rural areas.

4. Use the job creation potential of the green economy to reduce industrial segregation. The countries of the South Caucasus and Western CIS are in a strong position to use the job creation potential of the green economy to strengthen their labor markets and to reduce the industrial segregation by gender (OECD 2011a). The expansion in the capacity of the green sector and the development of alternative energy sources can provide an opportunity for femalefriendly employment creation. However, investments into education and nurturing a gender-balanced system of educational attainment will be needed in order to realize this potential. 
5. Include a strong impact evaluation element into the proposed policies. Impact evaluation elements need to be incorporated into the policy design. The impact evaluations can then contribute to providing a new evidence-based framework for how best to empower women (Buvinić et al. 2013; O’Sullivan 2014). 


\section{REFERENCES}

Academic Swiss Caucasus Net. 2014. "Emergence of Entrepreneurship in Georgia: Midterm Results." Report. Tbilisi.

Aculai, E., A. Bulgac, V. Gryga, O. Krasovksa, and O. Linchevskaya. 2009. "Researching the Gender Aspect in Business Development (the Case of Moldova, Ukraine, and Belarus)." Lex ET Scientia International Journal 16(1).

Antonopoulos, R., and K. Kim. 2011. "Public Job-creation Programs: The Economic Benefits of Investing in Social Care View Less: Case Studies in South Africa and the United States." Levy Economics Institute of Bard College Working Paper \#671, May.

Arias O.S., and C. Sanchez-Paramo. 2014. "Back to Work: Growing with Jobs in Europe and Central Asia." Washington, DC: World Bank.

Atamanov, A., and M. Van den Berg. 2012. "Heterogeneous Effects of International Migration and Remittances on Crop Income: Evidence from the Kyrgyz Republic." World Development 40(3): 620-30.

Atasoy, H. 2015. "Latent Entrepreneurship in Transition Economies." IZA World of Labor.

Azzari, C., and A. Zezza. 2011. "International Migration and Nutritional Outcomes in Tajikistan." Food Policy 36(1): 54-70.

Badurashvili, I., M. McKee, G. Tsuladze, F. Meslé, J. Vallin, and V. Shkolnikov. 2001. "Where There are No Data: What Happened to Life Expectancy in Georgia since 1990?" Public Health 115: 394-400.

Blouchoutzim, A., and C. Nikas. 2014. "Emigrants' Remittances and Economic Growth in Small Transition Economies: The Cases of Moldova and Albania." East-West Journal of Economics and Business 17(2): 97-117.

Bohme, M.H., R. Persian, and T. Stohr. 2015. "Alone but Better Off? Adult Child Migration and Health of Elderly Parents in Moldova.” Journal of Health Economics 39: 211-27.

Bouton, L., S. Paul, and E.R. Tiongson. 2011. "The Impact of Emigration on Source Country Wages: Evidence from the Republic of Moldova." The World Bank Policy Research Working Paper \# 5764.

Brown, R.P.C., F. Carmignani, and F. Ghada. 2013. "Migrants' Remittances and Financial Development: Macro- and Micro-Level Evidence of a Perverse Relationship." The World Economy 36(5): 636-60. 
Brown, J.D., J. Earle, V. Gimpelson, R. Kapeliushnikov, H. Lehmann, Á. Telegdy, I. Vantu, R. Visan, and A. Voicu. 2006. "Nonstandard Forms and Measures of Employment and Unemployment in Transition: A Comparative Study of Estonia, Romania and Russia." IZA Discussion Paper 1961.

Bruhn, M., and B. Zia. 2013. "Stimulating Managerial Capital in Emerging Markets: The Impact of Business and Financial Literacy for Young Entrepreneurs." Journal of Development Effectiveness 5(2): 232-66.

Brunarska, Z., J. Nestorowicz, and S. Markowski. 2014. "Intra- vs. extra-regional migration in the post-Soviet space." Eurasian Geography and Economics 55(2): 133-55.

Buckley, C., and E.T. Hofmann. 2012. "Are Remittances an Effective Mechanism for Development?” Journal of Development Studies 48(8): 1121-38.

Buvinić M., R. Furst-Nichols, and E. Courey Pryor. 2013. “A Roadmap for Promoting Women's Economic Empowerment.” UN Foundation and Exxon Mobil Foundation.

Çagatay, N. 1998. "Engendering Macroeconomics and Macroeconomic Policies.” United Nations Development Program (UNDP) Working Paper 6.

Cantarji, V., and G. Mincu. 2013. "Costs and Benefits of Labour Mobility between the EU and the Eastern Partnership Partner Countries. Country Report: Moldova.” Center for Social and Economic Research (CASE) Study 465.

Cashin, C.E., M. Borowitz, and O. Zuess. 2002. "The Gender Gap in Primary Health Care Resource Utilization in Central Asia.” Health Policy and Planning 17(3): 264-72.

Cockerham, W.C., B.P. Hinote, and P. Abbott. 2006. "Psychological Distress, Gender, and Health Lifestyles in Belarus, Kazakhstan, Russia, and Ukraine." Social Science and Medicine 63: 2381-94.

Cockerham, W.C., B.P. Hinote, P. Abbott, and C. Haerpfer. 2004. "Health Lifestyles in Central Asia: the Case of Kazakhstan and Kyrgyzstan." Social Science and Medicine 59: 140921.

Danzer, A., and B. Dietz. 2014. "Labour Migration from Eastern Europe and the EU's Quest for Talents." Journal of Common Market Studies 52(2): 183-99.

Demirgüç-Kunt, A., L. Klapper, D. Singer, and P. Van Oudheusden. 2015. "The Global Findex Database 2014: Measuring Financial Inclusion around the World.” World Bank Policy Research Working Paper 7255, April.

Dermendzhieva, Z. 2011. "Emigration from the South Caucasus: who goes abroad and what are the economic implications?" Post-Communist Economies 23(3): 377-98. 
Duthé, G., F. Meslé, J. Vallin, I. Badurashvili, and K. Kuyumjyan. 2012. "High Sex Ratios at Birth in the Caucasus: Modern Technology to Satisfy Old Desires.” Population and Development Review 38(3): 487-501.

Elborgh-Woytek, K., M. Newiak, K. Kochhar, S. Fabrizio, K. Kpodar, P. Wingender, B. Clements, and G. Schwartz. 2013. "Women, Work, and the Economy: Macroeconomic Gains from Gender Equity." IMF Staff Discussion Note 13/10, September.

European Monitoring Centre for Drugs and Drug Addiction. 2015. "Country Overview: Kyrgyzstan.”

Falkingham, J. 2003. "Inequality and Changes in Women's Use of Maternal Health-care Services in Tajikistan.” Studies in Family Planning 34(1): 32-43.

Food and Agriculture Organization (FAO). 2014. "Rural Women in Eastern Europe and Central Asia.” Report. Rome.

FAO. 2011. "The State of Food and Agriculture: Women in Agriculture, Closing the Gender Gap for Development 2010-2011." Report. Rome.

Farré, L., and N. Rodríguez-Planas. 2014. "Immigrants from Eastern Partnership (EaP) Countries in Spain.” IZA Journal of European Labor Studies 3(1).

Flabbi, L. 2011. "Gender Differences in Education, Career Choice and Labor Market Outcomes on a Sample of OECD Countries." Background paper for the World Development Report 2012.

Gang, I. 2014. "Migration, Education and the Gender Gap in Labour Force Participation." Economics Department Working Paper Series, Rutgers University.

Ganguli, I., and K. Terrell. 2006. "Institutions, Markets and Men's and Women's Wage Inequality: Evidence from Ukraine.” Journal of Comparative Economics 34(2): 200-27.

Görlich D., O.T. Mahmoud, and T. Christoph. 2007. "Explaining Labour Market Inactivity in Migrant-Sending Families: Housework, Hammock, or Higher Education?” Kiel Working Paper No. 1391.

Grigsby, M., E. Español, and D.J. O’Brien. 2012. “The Influence of Farm Size on Gendered Involvement in Crop Cultivation and Decision-making Responsibility of Moldovan Farmers." East European Countryside 18.

Guarcello, L., S. Lyon, F.C. Rosati, and C. Valdivia. 2005. "School to work transitions in Georgia : a preliminary analysis based on household budget survey data." Understanding Children's Work Project Working Paper Series. 
Guilmoto, C.Z. 2009. "The Sex Ratio Transition in Asia." Population and Development Review 35(3): 519-49.

Guliev, F. 2015. “The Informal Economy in Azerbaijan.” Caucasus Analytical Digest 75(July).

Haeck. C., P. Lefebvre, and P. Merrigan. 2015. "Canadian Evidence on Ten Years of Universal Preschool Policies: The Good and the Bad." Labour Economics 36: 137-57.

İlkkaracan, İ., K. Kim, and T. Kaya. 2015. "The Impact of Public Investment in Social Care Services on Employment, Gender Equality, and Poverty: The Turkish Case." Research Project Report, Levy Economics Institute of Bard College. August.

Isakova, N.B., O. Krasovska, L. Kavunenko, and A. Lugovy. 2006. “Women’s Entrepreneurship in Former Soviet Republics: Entrepreneurship in the Ukraine: a Male Female Comparison." in Welter, E., D. Smallbone, and N.B. Isakova (eds.) Enterprising Women in Transition Economies. Burlington, VT: Ashgate.

Jashi, Ch. 2004. "Development of Women's Entrepreneurship: the Case of Georgia." in UNECE (2004) Access to Financing and ICT for Women Entrepreneurs in the UNECE Region: Challenges and Good Practices. Geneva and New York.

Johnson, S. 2005. "Gender Relations, Empowerment and Microcredit: Moving on From a Lost Decade." European Journal of Development Research 17(2): 224-48.

Joshi, D., and M. Och. 2014. "Talking About My Generation and Class? Unpacking the Descriptive Representation of Women in Asian Parliaments." Women's Studies International Forum 47(1): 168-79.

Justino, P., and O.N. Shemyakina. 2012. "Remittances and Labor Supply in Post-Soviet Tajikistan." IZA Journal of Labor and Development 1.

Kabeer, N. 2012. "Women's Economic Empowerment and Inclusive Growth: Labor Markets and Enterprise Development." Supporting Inclusive Growth (SIG) Working Paper 2012/1.

Khitarishvili, T. 2013. "Evaluating the Gender Wage Gap in Georgia, 2004-2011.” Levy Economics Institute of Bard College Working Paper \#768, July.

Kupets, O. 2015. "Education in Transition and Job Mismatch: Evidence from the Skills Survey in non-EU Transition Countries." KIER Discussion Paper Series.

Kuriakose, S. 2013a. "Fostering Entrepreneurship in Armenia." Washington, DC: World Bank.

Kuriakose, S. 2013b. "Fostering Entrepreneurship in Azerbaijan.” Washington, DC: World Bank.

Kuriakose, S. 2013c. "Fostering Entrepreneurship in Georgia." Washington, DC: World Bank. 
Lastarria-Cornhiel, S. 2006. "Feminization of Agriculture: Trends and Driving Forces." RimispLatin American Center for Rural Development, Santiago, Chile. Available at: http://siteresources.worldbank.org/INTWDRS/Resources/4773651327599046334/8394679-1327599874257/LastarriaCornhiel_FeminizationOfAgri.pdf

Liebensteiner, M. 2014. "Estimating the Income Gain of Seasonal Labor Migration." Review of Development Economics 18(4): 667-80.

Lokshin, M. 2004. "Household Childcare Choices and Women's Work Behavior in Russia." Journal of Human Resources 2: 1094-115.

Marchetti, S., D. Piazzalunga, and A. Venturini. 2014. "Does Italy Represent an Opportunity for Temporary Migrants from the Eastern Partnership Countries?" IZA Journal of European Labor Studies 3.

Menjívar, C., and V. Agadjanian. 2007. "Men's Migration and Women's Lives: Views from Rural Armenia and Guatemala." Social Science Quarterly 88(5): 1243-62.

Meurs, M., and V Slavchevska. 2014. "Doing it All: Women's Employment and Reproductive Work in Tajikistan." Journal of Comparative Economics 42: 786-803.

Meurs, M. and L.A. Giddings. 2012. "Maternal Healthcare in Tajikistan: A Bargaining Framework." Feminist Economics 18(3): 109-40.

Miluka, J. 2009. "Moldova Farm Survey Gender Assessment.” Washington, DC: Millennium Challenge Corporation.

National Bureau of Statistics of the Republic of Moldova. 2014a. "Women and Men in Agriculture in the Republic of Moldova." Statistical Booklet. Chisinau.

National Bureau of Statistics of the Republic of Moldova. 2014b. "Time Use by Moldovan Parents for Taking Care of Their Children.” Analytic Note. Chisinau.

National Bureau of Statistics of the Republic of Moldova. 2012. "Women and Men in the Republic of Moldova: Analysis from a Territorial Perspective." Chisinau.

National Statistical Committee of the Republic of Belarus. 2013. "Republic of Belarus: Multiple Indicator Cluster Survey of Children and Women 2012, Preliminary Findings.” Minsk.

National Statistical Committee of the Republic of Belarus. 2010. "Women and Men of the Republic of Belarus: Statistical Book.” Minsk.

National Statistical Service of the Republic of Armenia. 2014. "Women and Men in Armenia." Yerevan. 
National Statistical Service of the Republic of Armenia. 2009. "Report on Time Use Survey in the Republic of Armenia." NSSRA with the assistance of Statistics Sweden and the financial support of SIDA. Yerevan.

National Statistical Service of the Republic of Armenia. 2008. "Report on Time Use Sample Survey in the Republic of Armenia." Yerevan.

Nedoluzhko, L., and V. Agadjanian. 2015. "Between tradition and modernity: Marriage dynamics in Central Asia." Demography 52(3): 861-82

OECD. 2012. "Closing the Gender Gap: Act Now." Paris and Washington, DC: OECD.

OECD. 2011a. "Development in Eastern Europe and the South Caucasus: Armenia, Azerbaijan, Georgia, Republic of Moldova, and Ukraine.” Paris and Washington, DC: OECD.

OECD. 2011b. "How do People in the Asia/Pacific Region Spend Their Time?" in Society at a Glance Asia/Pacific Edition. Paris and Washington, DC: OECD.

OECD. 2009. "Society at a Glance 2009: OECD Social Indicators.” Paris and Washington, DC: OECD.

O’Sullivan, M., A. Rao, R. Banerjee, K. Gulati, and M. Vinez. 2014. "Levelling the field: improving opportunities for women farmers in Africa." Washington, DC: World Bank.

Otiashvili, D., I. Kirtadze, K.E. O’Grady, W. Zule, E. Krupitsky, W.M. Wechsberg, and H.E. Jones. 2013. "Access to Treatment for Substance-using Women in the Republic of Georgia: Socio-cultural and Structural Barriers.” International Journal of Drug Policy 24: $566-72$.

Paravaya, O. 2011. "Gender Differences of Suicidal Behavior in Belarus: Epidemiology." European Psychiatry 26(Supplement 1): 1633.

Pastore, F., and A. Verashchagina. 2011. "When does transition increase the gender wage gap?" Economics of Transition 19: 333-69.

Pellillo A., I. Kochlamazashvili, and N. Kakulia. 2014. "Agriculture and Rural Development in Western Georgia: A Baseline Assessment.” Report of the European Neighborhood Program for Agriculture and Rural Development (ENPARD), Georgia.

Pignatti, N. 2012. “Gender Wage Gap Dynamics in a Changing Ukraine.” IZA Journal of Labor and Development 1.

Rani, M., and S. Bonu. 2009. "Attitudes Toward Wife Beating: A Cross-Country Study in Asia." Journal of Interpersonal Violence 24(8): 1371-97. 
Razvodovsky, Y. 2011. "Alcohol Consumption and Suicide in Belarus: 1980-2005.” Suicidology Online 2:1-7.

Razvodovsky, Y. and A. Stickley. 2009. "Suicide in Urban and Rural Regions of Belarus, 19902005." Public Health 123: 27-31.

Rechel, B., B. Roberts, E. Richardson, S. Shishkin., V.M. Shkolnikov, D.A. Leon, M. Bobak, M. Karanikolos, and M. McKee. 2013. "Health and Health Systems in the Commonwealth of Independent States." The Lancet 381: 1145-55.

Rutkowski, J. 2013. "Georgia: Skills Mismatch and Unemployment, Labor Market Challenges." World Bank Report No. 72824-GE.

Sattar, S. 2012. "Opportunities for Men and Women: Emerging Europe and Central Asia." Washington, DC: World Bank.

Schneider, F., A. Buehn, and C.E. Montenegro. 2010. "Shadow Economies All Over the World: New Estimates for 162 Countries from 1999 to 2007." The World Bank Policy Research Working Paper 5356.

Smallbone, D., and F. Welter. 2010. "Entrepreneurship and Government Policy in Former Soviet Republics: Belarus and Estonia Compared." Environment and Planning C: Government and Policy 28: 195-210.

State Statistics Service of Ukraine. 2012. "Women and Men in Ukraine: Statistical Collection." Kyiv.

Stoet, G., and D.C. Geary. 2015. "Sex Differences in Academic Achievement Are Not Related to Political, Economic, or Social Equality." Intelligence 48: 137-51.

Stöhr, T. 2015. "Siblings' interaction in migration decisions: who provides for the elderly left behind?" Journal of Population Economics 28(3).

UNDP, SIDA. 2003. "Gender Issues in Ukraine: Challenges and Opportunities.” Kyiv.

UNECE. 2012. "Promoting Gender Equality and Women's Economic Empowerment on the Road to Sustainable Development: Good Practices from the UNECE Region." Geneva.

UNFPA. 2014. "Analytical Research on Women's Participation in the Labour Force in Ukraine." New York.

USAID. 2013. "Gender Analysis of Agriculture in the Europe and Eurasia Region." Washington, DC. 
van Klaveren, M., K. Tijdens, M. Hughie-Williams, and N. Ramos Martin. 2010. "An Overview of Women's Work and Employment in Kazakhstan." Working Paper 10-93, Amsterdam Institute for Advanced Labour Studies, University of Amsterdam.

Walker, J., N. Berekashvili, and N. Lomidze. 2014. "Valuing Time: Time Use Survey, the Capabilities Approach, and Gender Analysis." Human Development and Capabilities 15(1): 47-59.

Welter, F., D. Smallbone, and N.B. Isakova. 2006. "Conclusions and Policy Perspectives." in E. Welter, D. Smallbone, and N.B. Isakova (eds.) Enterprising Women in Transition Economies. Burlington, VT: Ashgate.

Wiegers, T.A., W.G.W. Boerma, and O. de Haan. 2010. "Maternity Care and Birth Preparedness in Rural Kyrgyzstan and Tajikistan." Sexual and Productive Healthcare 1: 189-94.

Woetzel, J., A. Madgavkar, K. Ellingrud, E. Labaye, S. Devillard, E. Kutcher, J. Manyika, R. Dobbs, and M. Krishnan. 2015. "How Advancing Women's Equality Can Add \$12 Trillion to Global Growth." McKinsey Global Institute Report, September.

World Bank. 2015. "Women, Business and the Law 2016: Getting to Equal." Washington, DC: World Bank.

World Bank. 2013. "Gender at Work: A Companion to the World Development Report on Jobs." Washington, DC: World Bank.

World Economic Forum. 2014. “The Global Gender Gap Report.” Geneva.

Zurabishvili, T. 2013. "Migration Network of Labor Migrants from Tianeti." Unpublished manuscript.

Data sources used: WB Gender Statistics Database; UNECE Gender Statistics Database; FAO Gender and Land Rights Database (http://www.fao.org/gender-landrights-database; accessed October 10, 2015); World Values Surveys; Demographic and Health Surveys; Multiple Indicator Cluster Surveys. 


\section{Appendix}

Table A1. List of South Caucasus, Western CIS, and Central Asian Countries with Time Use Surveys

\begin{tabular}{|c|c|c|c|c|}
\hline Country & Year & Details & Source & $\begin{array}{l}\text { Data } \\
\text { Summary }\end{array}$ \\
\hline \multirow[t]{2}{*}{ Armenia } & 2004 & $\begin{array}{l}\text { Two diaries, one for weekdays and one for } \\
\text { weekends: } 235 \text { people, } 60 \text { households, } 15-80 \text { years } \\
\text { old (pilot); } 5 \text { towns and } 4 \text { villages in } 9 \text { administrative } \\
\text { territorial divisions; } 176 \text { people in } 60 \text { households } \\
\text { (according to the UNSD site) }\end{array}$ & $\begin{array}{l}\text { OECD (2011) "How do People in the Asia/Pacific Spend } \\
\text { Their Time" Society at a Glance 2011, p.13; } \\
\text { National Statistical Service of the Republic of Armenia } \\
\text { (2005) "Report on Time Use Sample Survey in the Republic } \\
\text { of Armenia, July } 11-31,2004 \text { " Yerevan. }\end{array}$ & Yes, report \\
\hline & 2008 & $\begin{array}{l}\text { Two diaries, one for weekdays and one for } \\
\text { weekends: 1,342 people, } 512 \text { households, Oct } 1 \text { - } \\
\text { 31, 2008, 15-80 years old; UNECE Stat Div } \\
\text { Database; Gender Stats Database }\end{array}$ & $\begin{array}{l}\text { OECD (2011); National Statistical Service of the Republic of } \\
\text { Armenia (2009) "Report on Time Use Sample Survey in the } \\
\text { Republic of Armenia, October 1-31, 2008" Yerevan. }\end{array}$ & Yes, report \\
\hline \multirow[t]{2}{*}{ Azerbaijan } & 2008 & $\begin{array}{l}9,633 \text { households and their members over } 15 \text { years } \\
\text { of age by HETUS recommendations; } \\
\text { January1-December } 31,2008 \text {. The next TUS in } \\
\text { Azerbaijan Republic is planned for } 2012 \text {. } \\
\text { ( } 2008 \text { gender disaggregated data obtained from the } \\
\text { Statestatcom website); no other details available. }\end{array}$ & $\begin{array}{l}\text { Statestatcom of Azerbaijan Republic; } \\
\text { Statistical Commission and Economic Commission for } \\
\text { Europe (2010) “In-depth Review of Time-Use Surveys: } \\
\text { Country Comments” presented at the Conference of } \\
\text { European Statisticians, Geneva, November 3-4, } 2010 .\end{array}$ & Yes, website \\
\hline & 2012 & ? (no information available on the website) & $\operatorname{SCECE}(2010)$ & No \\
\hline \multirow[t]{2}{*}{ Belarus } & 2004 & $\begin{array}{l}2,000 \text { households, } 4,400 \text { persons, } 12 \text { years of older } \\
\text { (subset of the survey of household expenses and } \\
\text { incomes ( } 98.5 \text { percent response rate); } 24 \text {-hour diary } \\
\text { with } 10 \text {-minute slots }\end{array}$ & $\operatorname{SCECE}(2010)$, p. 23 & No \\
\hline & $\begin{array}{l}2014- \\
2015\end{array}$ & $\begin{array}{l}\text { April 2014-March } 2015 \text { (currently in progress); } \\
6,000 \text { households ( } 0.2 \text { percent of total households) } \\
\text { and their members } 10 \text { years and older; } \\
\text { Two diaries: weekdays and weekends; } \\
\text { 7hh (time): “Time-Use Diary (for persons aged } 15 \\
\text { and older) } \\
7 \text { hh (time-children): "Time-Use Diary (for children } \\
\text { aged 10-14 years) } \\
\text { UNFPA and UNICEF }\end{array}$ & $\begin{array}{l}\text { "National Statistical Committee of the Republic of Belarus: } \\
\text { Time-Use Survey" sheet } \\
\text { http://www.belstat.gov.by/en/gosudarstvennye- } \\
\text { statisticheskie-nablyudeniya/vyborochnye- } \\
\text { obsledovaniya/time-use-survey/ (accessed 9/22/2015) } \\
\text { http://www.belstat.gov.by/uploads/file/U_uroven/voprosn } \\
\text { iki/7_dx_time_budget.pdf } \\
\text { have the "with whom" question }\end{array}$ & No \\
\hline
\end{tabular}


Moldova

2012 June 1, 2011-May 31, 2012;

15,600 households, of which 10,642 accepted (68.2 percent);

24-hour diary for one household member 15 years and older;

One diary (either weekday or weekend).

Georgia 2011 Not representative: three municipalities (Adigeni, Aspindza, and Akhaltsikhe) in Samtsxe-Javaxeti; 8 villages, out of which 3 were Armenian villages, in each village about 120 participants (about half women and half men).

Mercy Corps "Market Alliances against Poverty" project

Kazakhstan

2006

years old 3,000 households and its young members 6-18 years old; 7 days; UNECE Stat Div Database; Gender Stats Database

201233,830 respondents aged 10 years and older; two 24-hour diaries: one for weekday and one for a weekend day with intervals of 10 minutes for a total of 144 intervals per day; UNECE Stat Div Database; Gender Stats Database

Kyrgyzstan 2005 20-74 years old; UNECE Stat Div Database; Gender Stats Database

2010 4,929 households; 12 years and older; questionnaire.
"Time Use Survey: Republic of Moldova" paper presented at the UNECE Work Session on Gender Statistics, March 19-21, 2014, Geneva.

J. Walker et al. (2014)

No
OECD (2011), p. 13; Dossanova (2014) paper presented at Gender Statistics Workshop.

Dossanova (2014)

OECD (2011), p. 13

Presentation from the "Workshop on Time-Use Data

Analysis" October 11-15, 2014.
Yes,

presentation

Additional data sources: Living Conditions, Lifestyles, and Health (LLH) project, funded by the Copernicus Program of the European Union (2001); Hinonte et al. (2009) 